\title{
Chemoselective Copper-Mediated Modification of Selenocysteines in Peptides and Proteins
}

\author{
Zhenguang Zhao, Daphna Shimon and Norman Metanis*
}

\section{Supplementary Information}

\section{Table of context}

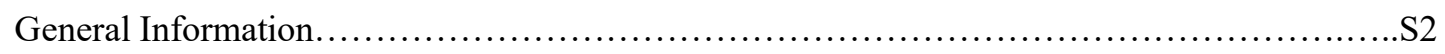

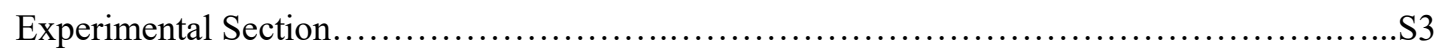

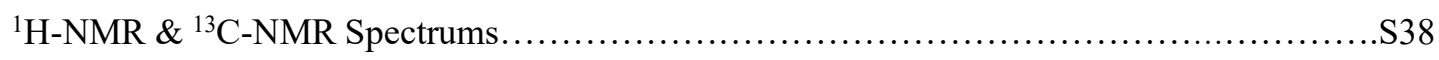

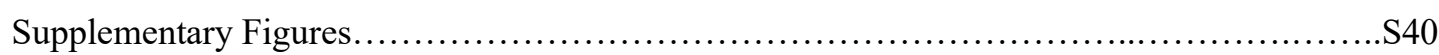

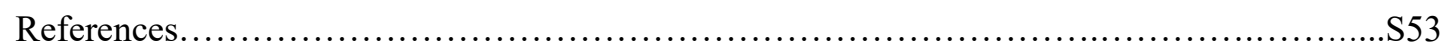




\section{General materials and methods}

\section{Reagents and materials}

All Fmoc-amino acids were purchased from CS Bio Co. (Menlo Park, CA) and Matrix Innovation (Quebec City, Canada). N,N,N',N'-Tetramethyl-O-(6-chloro-1H-benzotriazol-1-yl)uronium hexafluorophosphate (HCTU) and Ethyl cyano(hydroxyimino)acetate (OxymaPure) were purchased from Luxembourg Biotechnologies Ltd. (Rehovot, Israel). $\mathrm{Na}_{2} \mathrm{HPO}_{4} \cdot 12 \mathrm{H}_{2} \mathrm{O}$, 4mercaptophenylacetic acid (MPAA), $N, N^{\prime}$-Diisopropylcarbodiimide (DIC), triisopropylsilane (TIPS), tris(2-carboxyethyl)phosphine hydrochloride (TCEP· $\mathrm{HCl}), 2$, 2'-Dithiobis (5-nitropyridine) (DTNP), sodium ascorbate, $\mathrm{CuSO}_{4} \cdot 5 \mathrm{H}_{2} \mathrm{O}, 5,5$-Dimethyl-1-pyrroline N-oxide (DMPO), Seleno-Lcystine were purchased from Sigma-Aldrich. EDTA, disodium salt dihydrate was purchased from J. T. Baker. TentaGel® R RAM resin (loading $0.18 \mathrm{mmol} / \mathrm{g}$ ) and Chlorotrityl resin (loading 1.8 $\mathrm{mmol} / \mathrm{g}$ ) were purchased from Chem-Impex (USA). Mono-Fmoc ethylene diamine hydrochloride was purchased from Chem-Impex (USA) and Fmoc-Osu was purchased from Luxembourg Bio Technologies Ltd. Benzylhydrazine hydrochloride, isopropylhydrazine hydrochloride, isobutylhydrazine hydrochloride, 4-hydrazinylpyridine hydrochloride were purchased from Angene (USA). 4-Hydrazinobenzoic acid, 3,5-dimethylphenylhydrazine hydrochloride, (cyclopropylmethyl)hydrazine dihydrochloride and pentafluorophenylhydrazine were purchased from Alfa Aesar (Holland-Moran Inc. Israel). 4-Methoxylphenyldrazine hydrochloride was purchased from Fisher Scientific (Israel). All solvents: $N, N$-dimethylformamide (DMF), Diethyl ether $\left(\mathrm{Et}_{2} \mathrm{O}\right)$, dichloromethane $(\mathrm{DCM})$, acetonitrile $(\mathrm{MeCN}), N, N$-diisopropylethyl amine (DIEA), Trifluoroacetic acid (TFA) and piperidine (Pip) were purchased from Bio-Lab (Jerusalem, Israel) and were peptide synthesis, HPLC or ULC-grade. Buffers for all the reactions were prepared by using MilliQ water (Millipore, Merck). ${ }^{1} \mathrm{H}$ - and ${ }^{13} \mathrm{C}-\mathrm{NMR}$ spectra were recorded on a Bruker 400 or $500 \mathrm{MHz}$ instruments with chemical shifts reported in ppm relative to the residual deuterated solvent. Fmoc-Sec(Mob)-OH synthesis was reported previously. ${ }^{1}$

\section{High Performance Liquid Chromatography (HPLC)}

Analytical reversed-phase HPLC (RP-HPLC) was performed on Waters Alliance HPLC with 220 nm UV detection using a XSelect C18 column $(3.5 \mu \mathrm{m}, 130 \AA, 4.6 \times 150 \mathrm{~mm})$. Preparative and semi-preparative RP-HPLC was performed on a Waters LCQ150 system using a XBridge C18 column $(5 \mu \mathrm{m}, 30 \times 250 \mathrm{~mm})$ or XSelect C18 column $(5 \mu \mathrm{m}, 10 \times 150 \mathrm{~mm})$. Linear gradients of acetonitrile in water with $0.1 \%$ TFA were used for all systems to elute bound peptides. The flow rates were $1 \mathrm{~mL} / \mathrm{min}$ (analytical), $3.4 \mathrm{~mL} / \mathrm{min}$ (Semi-preparative), and $20 \mathrm{~mL} / \mathrm{min}$ (preparative).

\footnotetext{
Electrospray Ionization Mass Spectrometry (ESI-MS) and High-Resolution Mass Spectrometry (HR-MS)

ESI-MS was performed on an LCQ Fleet Ion Trap mass spectrometer (Thermo Scientific) in the positive mode. The HR-MS were recorded on an Agilent 6520 QTOF analyzer (Agilent Technologies, Inc., United States) with a dual electrospray ionization source. The raw data were deconvoluted using MagTran v1.03.
}

\section{Electron paramagnetic resonance (EPR)}

Continuous wave (CW) electron paramagnetic resonance (EPR) spectra were recorded on a Bruker micro EMX spectrometer operating at X-band $(9.27 \mathrm{GHz})$, equipped with a Bruker super-high-Q 
EPR cavity. Capillary tubes (O.D. $0.8 \mathrm{~mm}$, I.D $0.6 \mathrm{~mm}$ ) with the solutions were placed inside a standard $5 \mathrm{~mm}$ NMR tube for measurement. In all cases, the solution in the capillary extended out above of the EPR cavity. All experiments were performed at ambient conditions.

\section{Experimental Section}

\section{General procedure for Fmoc solid-phase peptide synthesis.}

Peptides were synthesized manually by Fmoc-SPPS typically on a $0.25 \mathrm{mmol}$ scale. Fmocdeprotection was carried out with $20 \%$ piperidine in DMF $(2 \times 10 \mathrm{~min})$. The Fmoc-amino acids (1 mmol in $5 \mathrm{~mL}$ of DMF, 4 equiv) were activated with HATU ( $1 \mathrm{mmol}$ in $5 \mathrm{~mL}$ of DMF, 4 equiv) and DIEA ( $2 \mathrm{mmol}$ in $5 \mathrm{~mL}$ of DMF, 8 equiv) for $5 \mathrm{~min}$ and allowed to couple for $30 \mathrm{~min}$ with constant shaking. Fmoc-Sec(Mob)-OH coupling was performed by DIC/OxymaPure procedure using 2 equiv of Fmoc-Sec(Mob)-OH. The resulting resins were washed with $\mathrm{DMF}(\times 3), \mathrm{DCM}(\times 3)$ and dried.

The peptides were cleaved off resin using a TFA:triisopropylsilane (TIPS):H2O (95:3:3) cocktail with 2 equiv DTNP (when Sec is present) ${ }^{2}$ for $2.5 \mathrm{~h}$ at room temperature. The cleavage mixture was filtered, and the resin was washed with TFA. The combined solutions were concentrated by $\mathrm{N}_{2}$ bubbling, to which 8 volumes of cold ether was added dropwise. The precipitated crude peptides were centrifuged, ether was removed, and the crude peptides were dissolved in MeCN:water (1:1) containing $0.1 \%$ TFA and further diluted to $\sim 25 \% \mathrm{MeCN}$ with water and lyophilized.

\section{General approach to peptide modification experiments}

Model peptides ( $20 \mu \mathrm{mol}, 1 \mathrm{a}-\mathrm{i})$ were dissolved in $1 \mathrm{~mL}$ PB buffer $(10 \mathrm{mM}, \mathrm{pH}$ ) as stock solution of peptide 1 (conc. $20 \mathrm{mM}$ with respect to the selenol monomer). $\mathrm{CuSO}_{4} \cdot 5 \mathrm{H}_{2} \mathrm{O}(40 \mu \mathrm{mol})$ was dissolved in $2 \mathrm{~mL}$ water (conc. $20 \mathrm{mM}$ ). The hydrazine reagents ( $40 \mu \mathrm{mol}, \mathbf{2 a}-\mathbf{l})$ were dissolved in $1 \mathrm{~mL}$ PB buffer (10 mM, pH 6, conc. $40 \mathrm{mM}$ ) as stock solution 2.

$50 \mu \mathrm{L}$ peptide 1 stock solution ( $1 \mu$ mol with respect to the selenol monomer) mixed with $50 \mu \mathrm{L}$ $\mathrm{CuSO}_{4}$ solution $(1 \mu \mathrm{mol})$ were dissolved in $600 \mu \mathrm{L}$ PB buffer $(10 \mathrm{mM}$, final $\mathrm{pH}$ 6, adjusted with 0.5 $\mathrm{M} \mathrm{NaOH}) .50 \mu \mathrm{L}$ hydrazine reagent stock solution $2(2 \mu \mathrm{mol})$ was dissolved in $250 \mu \mathrm{L}$ PB buffer (10 mM, pH 6). The two solutions were incubated at room temperature (for arylhydrazines) or 37 ${ }^{\circ} \mathrm{C}$ (for alkylhydrazines) for $5 \mathrm{~min}$. Then the hydrazine reagent solution was added dropwise to the mixture solution of peptide and $\mathrm{CuSO}_{4}$ (in $3 \mathrm{~min}$ ) and mixed uniformly by shaking after addition. The reaction mixture was incubated under open air at room temperature (for arylhydrazines) or 37 ${ }^{\circ} \mathrm{C}$ (for alkylhydrazines). The reaction progress was monitored by HPLC and LC-MS.

\section{Synthesis of Fmoc-4-hydrazinobenzoic acid}

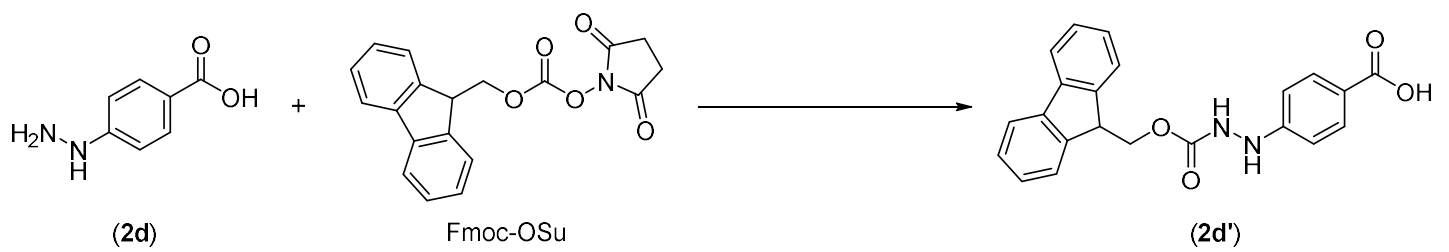

Scheme S1. The synthesis of Fmoc-4-hydrazinobenzoic acid

4-hydrazinobenzoic acid (2d, $2 \mathrm{~g}, 13.16 \mathrm{mmol})$ was suspended in $50 \mathrm{~mL} \mathrm{10 \%} \mathrm{Na}_{2} \mathrm{CO}_{3}$ aqueous 
solution, then cooled to $0{ }^{\circ} \mathrm{C}$ and a solution of Fmoc-OSu in dioxane $(25 \mathrm{~mL})$ was added dropwise to the reaction mixtures over a period of $1 \mathrm{~h}$. The reaction mixtures were warmed to room temperature and stirred for $12 \mathrm{~h}$. The reaction mixtures were washed by ether $(3 \times 50 \mathrm{~mL})$, the aqueous solution was acidified with $2 \mathrm{~N} \mathrm{HCl}$. The precipitate was filtered, washed with water $(5 \mathrm{x}$ $50 \mathrm{~mL}$ ) and then lyophilized to give the product (2d') as a colorless solid in $50 \%$ yield. The product was characterized by HRMS and NMR (Fig. S43).

${ }^{1} \mathrm{H}$ NMR $\left(500 \mathrm{MHz}, d_{7}\right.$-DMF) $\delta 12.53$ (bro, 1H), $9.45(\mathrm{~s}, 1 \mathrm{H}), 8.37(\mathrm{~s}, 1 \mathrm{H}), 7.97-7.95(\mathrm{~m}, 2 \mathrm{H}), 7.88-$ $7.79(\mathrm{~m}, 4 \mathrm{H}), 7.47-7.46(\mathrm{~m}, 2 \mathrm{H}), 7.43-7.39(\mathrm{~m}, 2 \mathrm{H}), 6.85-6.84(\mathrm{~m}, 2 \mathrm{H}), 4.47-4.46(\mathrm{~m}, 2 \mathrm{H}), 4.34-$ $4.31(\mathrm{~m}, 1 \mathrm{H}) ;{ }^{13} \mathrm{C}$ NMR $\left(125.8 \mathrm{MHz},\left(\mathrm{CD}_{3}\right)_{2} \mathrm{CO}\right) \delta 168.06,156.90,152.88,143.28,140.64,130.94$, 127.62, 127.02, 124.89, 124.63, 119.78, 110.65, 65.82, 46.60 .

HRMS: $[\mathrm{M}+\mathrm{H}]^{+}$375.1344, calc. 375.1345 , and for $[\mathrm{M}+\mathrm{Na}]^{+}$obs. 397.1160 , calc. 397.1159 .

\section{The synthesis of biotin containing phenylhydrazine 21}

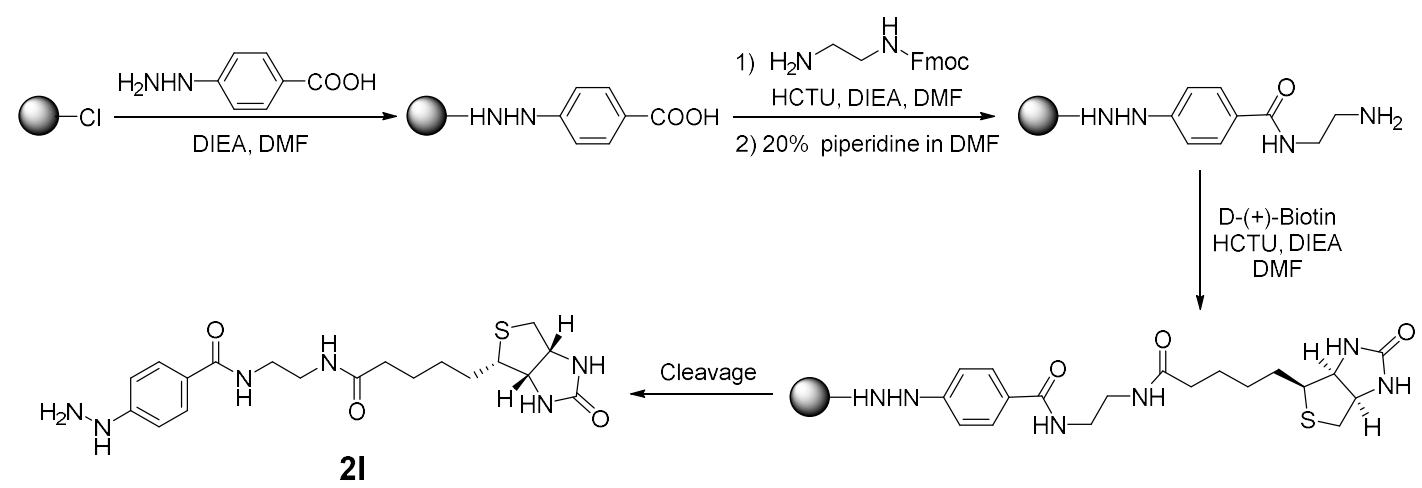

Scheme S2. The synthesis of biotin-containing phenylhydrazine 2 I

The synthesis of compound $\mathbf{2 l}$ was carried on the 2-chlorotrityl chloride resin (loading $0.5 \mathrm{mmol} / \mathrm{g}$, $0.25 \mathrm{mmol}$ scale). The resin was dried in vacuum overnight and the activated in DMF for $2 \mathrm{~h} .4-$ hydrazinobenzoic acid 2d (3 equiv) and DIEA (4 equiv) were dissolved in $8 \mathrm{~mL}$ DMF and then added to the resin, which was incubated in $\mathrm{N}_{2}$ atmosphere on shaker. After $18 \mathrm{~h}$, the resin was washed well by DMF and DCM. Mono-Fmoc ethylene diamine hydrochloride (3 equiv), HCTU (2 equiv) and DIEA (7 equiv) were added to the resin and incubated on shaker. After 2 h, Fmocdeprotection was conducted twice with $20 \%$ piperidine in DMF (5 min and $15 \mathrm{~min}$ ). The $D-(+)-$ biotin ( 2 equiv) coupling was carried out with HCTU (2 equiv) and DIEA ( 4 equiv). After $5 \mathrm{~h}$, the resin was washed with DMF and DCM, and then dried in vacuum overnight. The cleavage of resin performed with a mixture solution of TFA and water (99:1) in $\mathrm{N}_{2}$ atmosphere for $2 \mathrm{~h}$. The cleavage mixture was filtered, and the resin was washed with TFA. The combined solutions were concentrated by $\mathrm{N}_{2}$ bubbling, to which 8 volumes of cold ether was added dropwise. The precipitated crude compounds were centrifuged, ether was removed, and the crude compounds were dissolved in MeCN:water (1:1) containing 0.1\% TFA and further diluted to 25\% MeCN with water and purification by prep. RP-HPLC. The compound was obtained with $30 \%$ yield and characterized by ESI-MS ([M $+\mathrm{H}]^{+}$obs. 421.250, calc. for 421.201, Fig. S53) and NMR (Fig. S44).

${ }^{1} \mathrm{H}$ NMR (500 MHz, $d_{6}$-DMSO) $\delta 10.28$ (bro, 1H, TFA), 8.64 (bro, 1H), $8.38(\mathrm{t}, \mathrm{J}=11.18 \mathrm{~Hz}, 1 \mathrm{H})$, $7.98(\mathrm{t}, \mathrm{J}=11.45 \mathrm{~Hz}, 1 \mathrm{H}), 7.83(\mathrm{~d}, \mathrm{~J}=8.90 \mathrm{~Hz}, 2 \mathrm{H}), 6.98(\mathrm{~d}, \mathrm{~J}=8.77 \mathrm{~Hz}, 2 \mathrm{H}), 6.46-6.42(\mathrm{~m}, 2 \mathrm{H})$, 4.54 (bro, 2H), 4.35-4.32 (m, 1H), 4.15-4.13 (m, 1H), 3.34-3.30 (m, 2H), 3.26-3.32 (m, 2H), 3.12- 
$3.08(\mathrm{~m}, 1 \mathrm{H}), 2.86-2.83(\mathrm{~m}, 1 \mathrm{H}), 2.62-2.60(\mathrm{~m}, 1 \mathrm{H}), 2.11(\mathrm{t}, \mathrm{J}=14.90 \mathrm{~Hz}, 2 \mathrm{H}), 1.67-1.44(\mathrm{~m}, 4 \mathrm{H})$, $1.39-1.26(\mathrm{~m}, 2 \mathrm{H}) ;{ }^{13} \mathrm{C}$ NMR $\left(125.8 \mathrm{MHz}, d_{6}\right.$-DMSO) $\delta 172.46,165.79,162.77,147.94,128.39$, 127.07, 113.04, 61.04, 59.23, 55.39, 39.85, 39.24, 38.33, 35.27, 28.18, 28.04, 25.27.

HRMS: $[\mathrm{M}+\mathrm{H}]^{+}$421.2017, calc. 421.2016 and $[\mathrm{M}+\mathrm{Na}]^{+}$obs. 443.1829, calc. $443.1836 \mathrm{Da}$.

\section{Preliminary research of radical chemistry by sodium ascorbate and radical clock reaction}

As a test for the radical reaction, the modification of the model peptide 1a was sufficiently suppressed in the presence of $100 \mathrm{mM}$ sodium ascorbate (Fig. S1). In addition, the existence of radical intermediates was confirmed via EPR (see below) and the "radical clock", in which the rupture of cyclopropyl ring in $\mathbf{2 k}$ generate the opening of cyclopropane ring, and formation of but1 -ene containing product $\mathbf{3 k}$ in this transformation (Fig. S14).
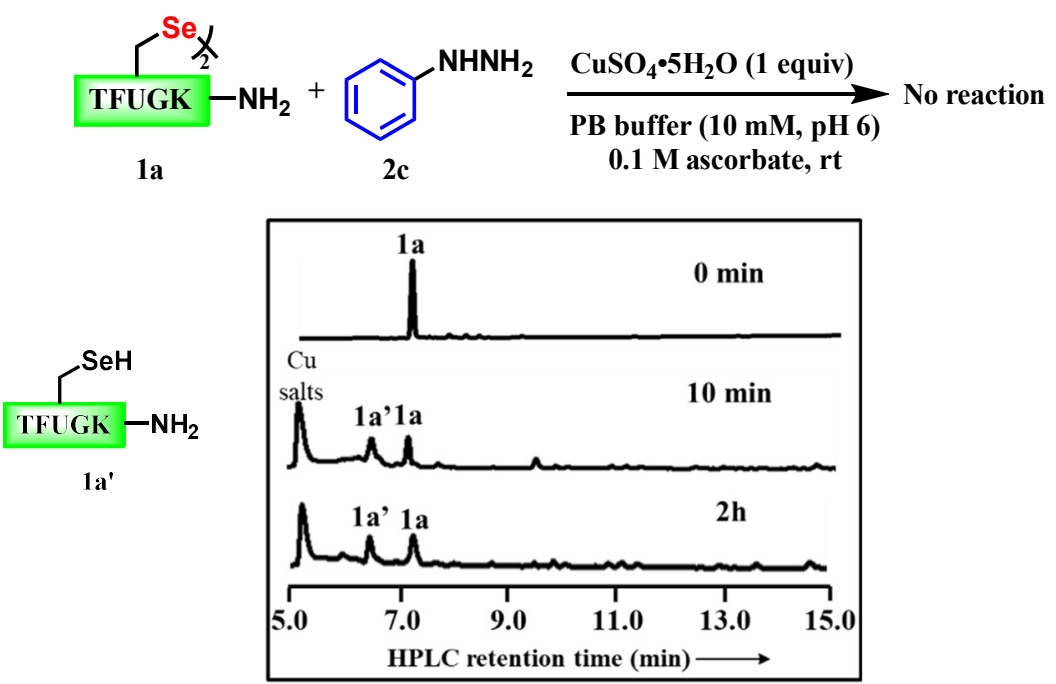

Figure S1. The inhibition of modification of $1 \mathbf{a}$ in the presence of radical quencher ascorbate

\section{Optimization of peptide modification}

The general approach for peptide modification, a stock solution of model peptide $1 \mathrm{a}$ ( $20 \mathrm{mM}$ with respect to the selenol monomer), 3,5-dimethylphenylhydrazine $2 \mathbf{2 a}(40 \mathrm{mM})$ and $\mathrm{CuSO}_{4}(20 \mathrm{mM})$ were prepared for the optimization of reaction conditions.

\section{The effect of the amount of $\mathrm{CuSO}_{4}$ on peptide modification}

Four aliquots of $50 \mu \mathrm{L}$ peptide 1a stock solution (1 $\mu \mathrm{mol}$ with respect to the selenol monomer) mixed with 0.5 equiv, 1.0 equiv, 2.0 equiv and 3.0 equiv $\mathrm{CuSO}_{4}$, respectively, were dissolved in $650 \mu \mathrm{L}$ PB buffer $(10 \mathrm{mM}$, final $\mathrm{pH} 6$, adjusted with $0.5 \mathrm{M} \mathrm{NaOH})$. Four aliquots of $50 \mu \mathrm{L}$ of hydrazine 2a stock solution ( $2 \mu \mathrm{mol})$ dissolved in $250 \mu \mathrm{L}$ PB buffer $(10 \mathrm{mM}$, pH 6$)$ were added dropwise to the corresponding mixtures of $1 \mathbf{a}$ and $\mathrm{CuSO}_{4}$. Then the reaction mixture was incubated at room temperature and the reaction progress was monitored by HPLC (using XSelect C18 column $(3.5 \mu \mathrm{m}, 130 \AA, 4.6 \times 150 \mathrm{~mm})$ with a gradient of $5 \% \mathrm{~B}$ over $5 \mathrm{~min}$ then $5-70 \%$ B over $20 \mathrm{~min}$ at $220 \mathrm{~nm}$ ) and LC-MS (Fig. S2, * is a side-product from 2a). 

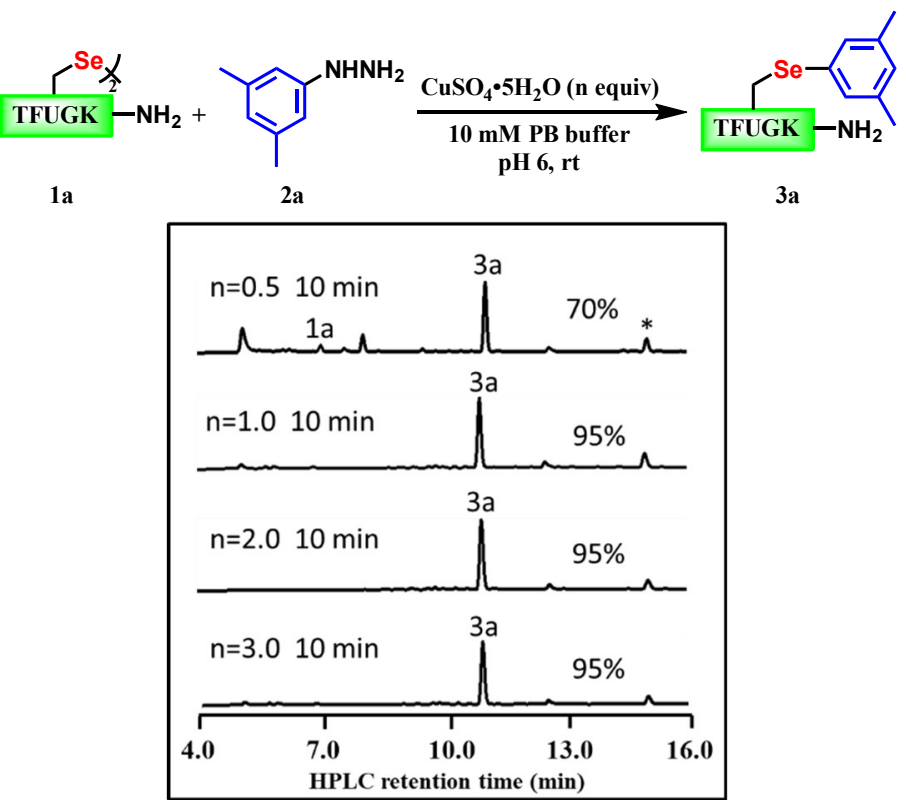

Figure S2. The effect of the amount of $\mathrm{CuSO}_{4}$ on peptide modification

\section{The effect of the amount of hydrazine reagents on peptide modification}

The peptide $1 \mathrm{a}\left(3.0 \mu \mathrm{mol}\right.$ with respect to the selenol monomer) and $\mathrm{CuSO}_{4}(3.0 \mu \mathrm{mol})$ dissolved in $2.1 \mathrm{~mL}$ PB buffer ( $10 \mathrm{mM}$, adjusted by $0.5 \mathrm{M} \mathrm{NaOH}$ to $\mathrm{pH}$ 6,) was divided into three different Eppendorf tubes. Three aliquots of $300 \mu \mathrm{L}$ hydrazine 2 a solution ( $10 \mathrm{mM}$ phosphate, $\mathrm{pH} 6)$ with 1.2 equiv, 1.5 equiv and 2 equiv of $\mathbf{2 a}$, respectively, were added dropwise to the above three Eppendorf tubes. The reaction mixture was incubated at room temperature, and the reaction progress was monitored by HPLC (using XSelect C18 column $(3.5 \mu \mathrm{m}, 130 \AA, 4.6 \times 150 \mathrm{~mm})$ with a gradient of 5\% B over $5 \mathrm{~min}$ then $5-70 \%$ B over $20 \mathrm{~min}$ at $220 \mathrm{~nm}$ ) and LC-MS (Fig. S3, * is a side-product from $\mathbf{2 a}$ ).

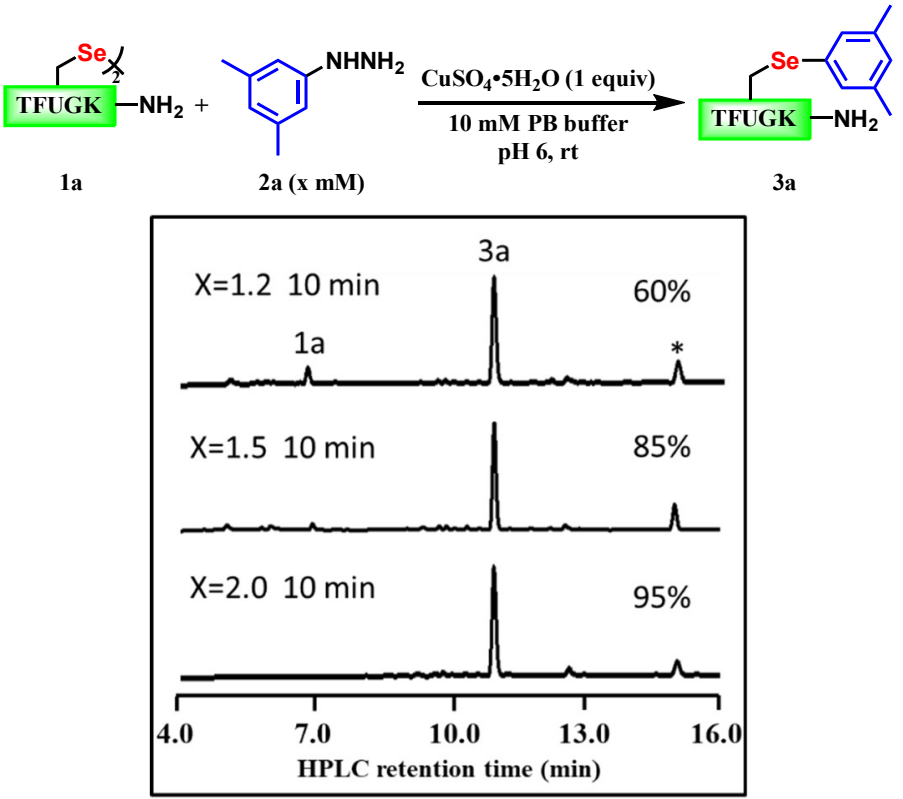

Figure S3. The effect of the amount of hydrazine reagents on peptide modification 


\section{The effect of $p H$ on peptide modification}

Six aliquots of $300 \mu \mathrm{L}$ hydrazine $2 \mathrm{a}$ solution ( $2 \mu$ mol each) at pH 4, pH 5, pH 6, pH 7, pH 10 and $\mathrm{pH} 13$, were added dropwise to corresponding six aliquots of $700 \mu \mathrm{L}$ mixture solution of $\mathrm{CuSO}_{4}(1 \mu \mathrm{mol}$ each $)$ and peptide $1 \mathrm{a}(1 \mu \mathrm{mol}$ with respect to the selenol monomer) at $\mathrm{pH} 4,5$, $6,7,10$ and 13, respectively. The reaction mixture was incubated at room temperature and monitored by HPLC (using XSelect C18 column $(3.5 \mu \mathrm{m}, 130 \AA, 4.6 \times 150 \mathrm{~mm})$ with a gradient of $5 \%$ B over $5 \mathrm{~min}$ then $5-70 \%$ B over $20 \mathrm{~min}$ at $220 \mathrm{~nm}$ ) and LC-MS (Fig. S4, \# is a side product from 1a, in which Sec converted to dehydroalanine, ${ }^{*}$ is a side-product from $\mathbf{2 a}$ ).

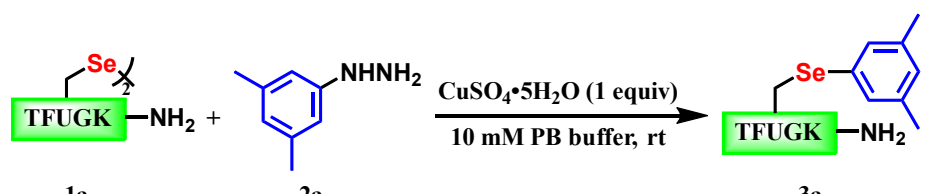

$1 a$

$3 \mathrm{a}$

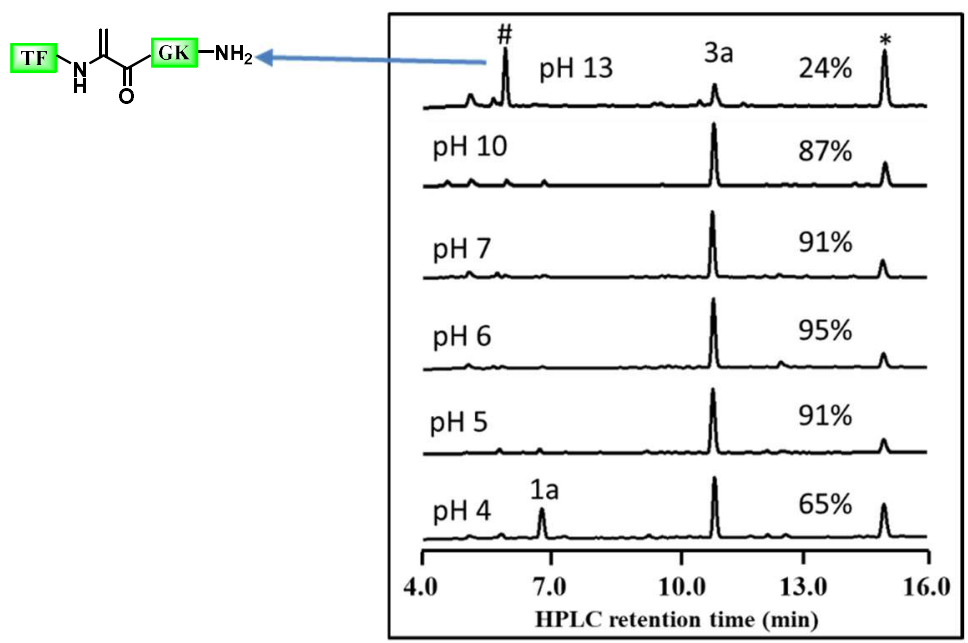

Figure $\mathbf{S 4}$. The effect of $\mathrm{pH}$ on peptide modification

\section{The modification of model peptide 1 a with different hydrazine reagents}

According to general approach for peptide modification, the stock solution of model peptide 1a (20 $\mathrm{mM}$ with respect to the selenol monomer), hydrazine reagents $\mathbf{2 b}-\mathbf{l}(40 \mathrm{mM})$ and $\mathrm{CuSO}_{4} \cdot 5 \mathrm{H}_{2} \mathrm{O}(20$ $\mathrm{mM}$ ) were prepared for peptide modification.

\section{The modification of model peptide $\mathbf{1 a}$ with 4-methoxylphenylhydrazine $\mathbf{2} \boldsymbol{b}$}

The peptide 1a (1 $\mu \mathrm{mol}$ with respect to the selenol monomer) and $\mathrm{CuSO}_{4}(1 \mu \mathrm{mol})$ dissolved in $700 \mu \mathrm{L}$ PB buffer (10 mM, pH 7) was incubated at room temperature for $5 \mathrm{~min} . \mathbf{2 b}(2 \mu \mathrm{mol})$ dissolved in $300 \mu \mathrm{L}$ PB buffer $(10 \mathrm{mM}, \mathrm{pH}$ 6) was added dropwise to the above reaction mixtures. The reaction mixture was incubated at room temperature, and the reaction progress was monitored by HPLC (using XSelect C18 column $(3.5 \mu \mathrm{m}, 130 \AA, 4.6 \times 150 \mathrm{~mm})$ with a gradient of 5\% B over $5 \mathrm{~min}$ then $5-70 \%$ B over $20 \mathrm{~min}$ at $220 \mathrm{~nm}$ ). After $10 \mathrm{~min}$, the product 3b was isolated in $75 \%$ yield. The product was characterized by ESI-MS $\left([\mathrm{M}+\mathrm{H}]^{+}\right.$obs. 708.25 , calc. 708.26, Fig. S5). 

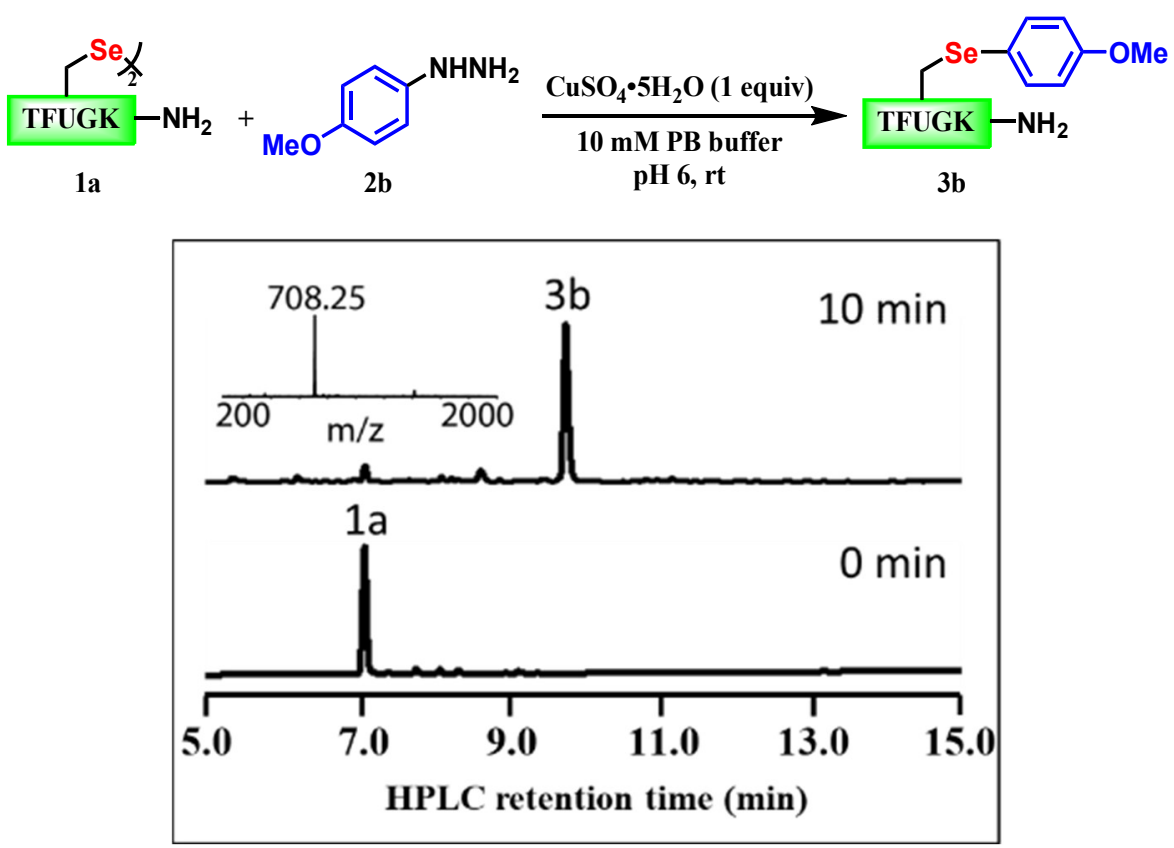

Figure S5. The modification of model peptide 1a with 4-methoxylphenylhydrazine 2b

2. The modification of model peptide $1 \mathbf{a}$ with phenylhydrazine $2 \mathrm{c}$

The peptide 1a $(1 \mu \mathrm{mol}$ with respect to the selenol monomer $)$ and $\mathrm{CuSO}_{4}(1 \mu \mathrm{mol})$ dissolved in $700 \mu \mathrm{L}$ PB buffer $(10 \mathrm{mM}, \mathrm{pH} 7)$ was incubated at room temperature for $5 \mathrm{~min} . \mathbf{2 c}(2 \mu \mathrm{mol})$ dissolved in $300 \mu \mathrm{L} \mathrm{PB}$ buffer $(10 \mathrm{mM}, \mathrm{pH} 6)$ was added dropwise to the above reaction solution. The reaction mixture was incubated at room temperature, and the reaction progress was monitored by HPLC (using XSelect C18 column $(3.5 \mu \mathrm{m}, 130 \AA, 4.6 \times 150 \mathrm{~mm})$ with a gradient of $5 \% \mathrm{~B}$ over $5 \mathrm{~min}$ then $5-70 \% \mathrm{~B}$ over $20 \mathrm{~min}$ at $220 \mathrm{~nm}$ ) and LC-MS. After $10 \mathrm{~min}$, the product 3c was isolated in $85 \%$ yield. The product was characterized by ESI-MS $\left([\mathrm{M}+\mathrm{H}]^{+}\right.$obs. 678.17 , calc. 678.25 , Fig. S6, * is a side-product from $\mathbf{2 c}$ ).

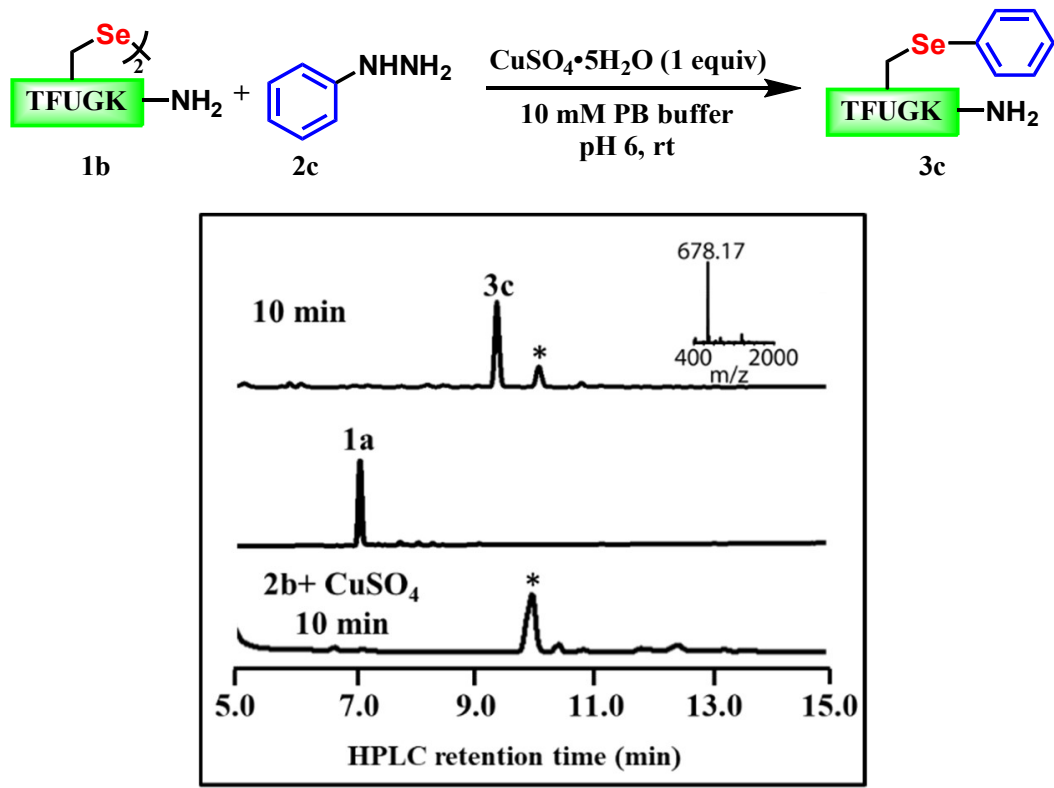

Figure S6. The modification of model peptide 1a with phenylhydrazine 2c. The bottom chromatogram shows the side-product formed by the reaction of phenylhydrazine and copper. 
3. The modification of model peptide $\mathbf{1} \boldsymbol{a}$ with 4-hydrazineylbenzoic acid $\mathbf{2 d}$

The peptide $1 \mathrm{a}(1 \mu \mathrm{mol}$ with respect to the selenol monomer $)$ and $\mathrm{CuSO}_{4}(1 \mu \mathrm{mol})$ dissolved in $700 \mu \mathrm{L}$ PB buffer $(10 \mathrm{mM}, \mathrm{pH}$ 7) was incubated at room temperature for $5 \mathrm{~min} . \mathbf{2 d}(2 \mu \mathrm{mol})$ dissolved in $300 \mu \mathrm{L}$ PB buffer ( $10 \mathrm{mM}$, pH 6 ) was added dropwise to the above reaction solution. The reaction mixture was incubated at room temperature, and the reaction progress was monitored by HPLC (using XSelect C18 column $(3.5 \mu \mathrm{m}, 130 \AA$, $4.6 \times 150 \mathrm{~mm})$ with a gradient of $5 \%$ B over $5 \mathrm{~min}$ then $5-70 \%$ B over $20 \mathrm{~min}$ at $220 \mathrm{~nm}$ ) and LC-MS. After $10 \mathrm{~min}$, the product 3d was isolated in $74 \%$. The product was characterized by ESI-MS $\left([\mathrm{M}+\mathrm{H}]^{+}\right.$obs. 722.17 , calc. 722.24, Fig. S7, * is a side-product from $\mathbf{2 d}$ ).

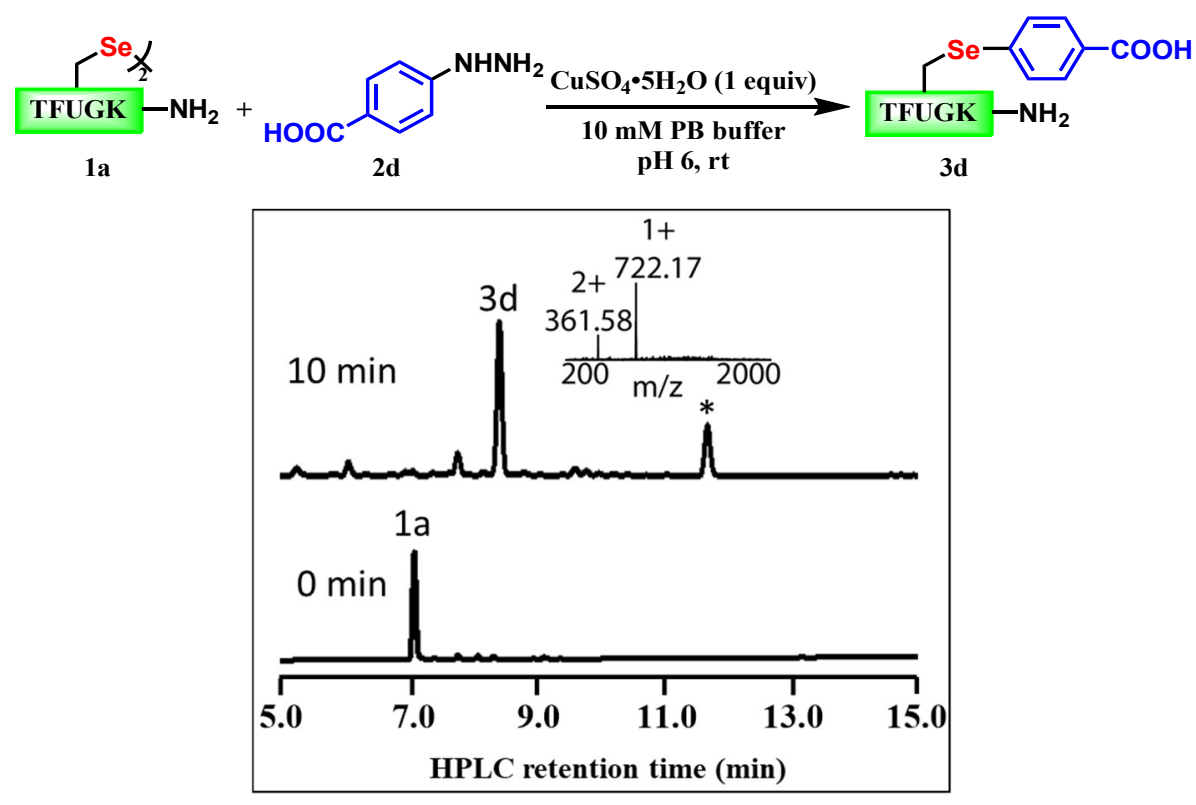

Figure S7. The modification of model peptide 1a with 4-hydrazineylbenzoic acid 2d

4. The modification of model peptide $1 \mathbf{a}$ with perfluorophenylhydrazine $2 \boldsymbol{e}$

The peptide $1 \mathrm{a}$ ( $1 \mu \mathrm{mol}$ with respect to the selenol monomer) and $\mathrm{CuSO}_{4}(1 \mu \mathrm{mol})$ dissolved in $700 \mu \mathrm{L}$ PB buffer $(10 \mathrm{mM}, \mathrm{pH} 7)$ was incubated at $37^{\circ} \mathrm{C}$ for $5 \mathrm{~min} .2 \mathrm{e}(2 \mu \mathrm{mol})$ dissolved in $300 \mu \mathrm{L}$ PB buffer ( $10 \mathrm{mM}, \mathrm{pH}$ 6) was incubated at $37^{\circ} \mathrm{C}$ for $5 \mathrm{~min}$ and then added dropwise to the above reaction solution. The reaction mixture was incubated at $37{ }^{\circ} \mathrm{C}$, and the reaction progress was monitored by HPLC (using XSelect C18 column $(3.5 \mu \mathrm{m}, 130 \AA, 4.6 \times 150 \mathrm{~mm}$ ) with a gradient of $5 \%$ B over $5 \mathrm{~min}$ then $5-70 \%$ B over $20 \mathrm{~min}$ at $220 \mathrm{~nm}$ ) and LC-MS. After 3 $\mathrm{h}$, the product $3 \mathrm{e}$ was observed by HPLC with a $19 \%$ conversion. The product was characterized by ESI-MS $(\mathrm{M}+\mathrm{H}]^{+}$obs. 768.17 , calc. 768.20 , Fig. S8).

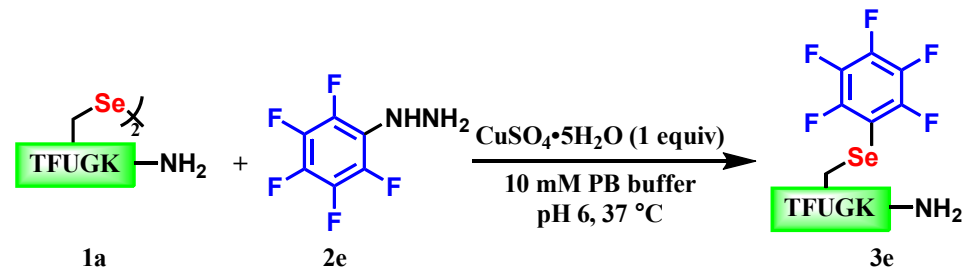




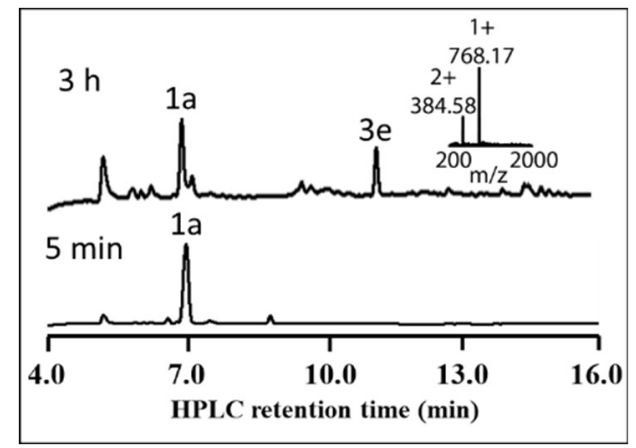

Figure S8. The modification of model peptide 1a with perfluorophenylhydrazine $\mathbf{2 e}$

5. The modification of model peptide 1a with 4-hydrazineylpyridine $\mathbf{2 f}$

The peptide 1a $(1 \mu \mathrm{mol}$ with respect to the selenol monomer $)$ and $\mathrm{CuSO}_{4}(1 \mu \mathrm{mol})$ dissolved in $700 \mu \mathrm{L}$ PB buffer $(10 \mathrm{mM}, \mathrm{pH} 7)$ was incubated at $37{ }^{\circ} \mathrm{C}$ for $5 \mathrm{~min} . \mathbf{2 f}(2 \mu \mathrm{mol})$ dissolved in $300 \mu \mathrm{L}$ PB buffer $\left(10 \mathrm{mM}, \mathrm{pH}\right.$ 6) was incubated at $37^{\circ} \mathrm{C}$ for $5 \mathrm{~min}$ and then added dropwise to the above reaction solution. The reaction mixture was incubated at $37{ }^{\circ} \mathrm{C}$, and the reaction progress was monitored by HPLC (using XSelect C18 column $(3.5 \mu \mathrm{m}, 130 \AA, 4.6 \times 150 \mathrm{~mm}$ ) with a gradient of $5 \%$ B over 5 min then $5-70 \%$ B over $20 \mathrm{~min}$ at $220 \mathrm{~nm}$ ) and LC-MS. After 2 $\mathrm{h}$, the product $\mathbf{3 f}$ was isolated in $60 \%$ yield. The product was characterized by ESI-MS ([M + H] $]^{+}$obs. 679.33, calc. 679.25, Fig. S9).

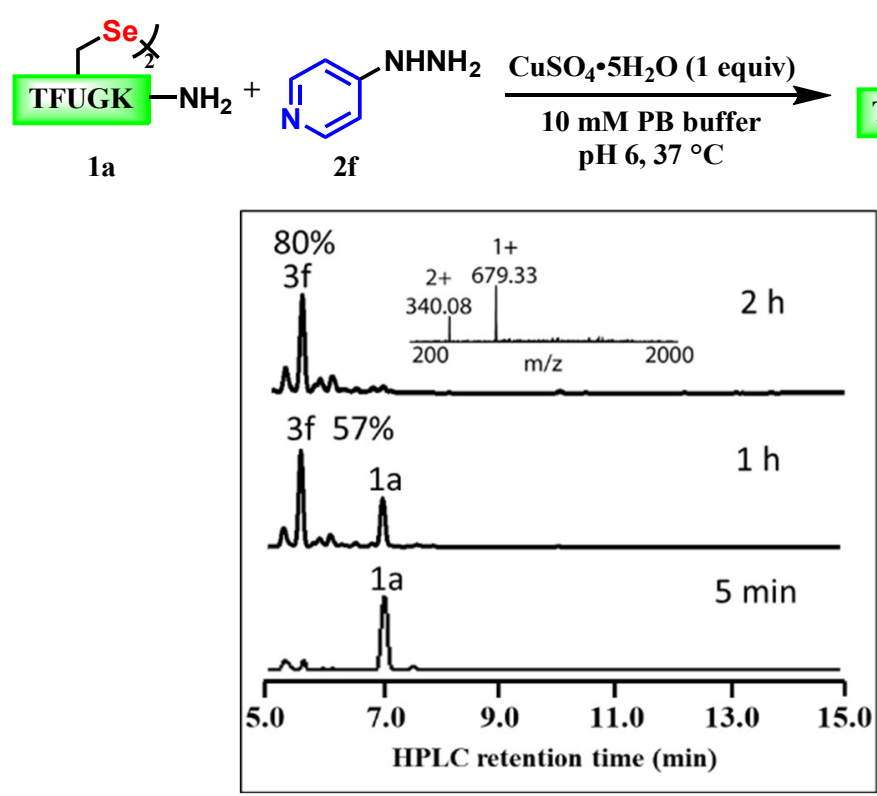

Figure S9. The modification of model peptide $\mathbf{1 a}$ with 4-hydrazineylpyridine $\mathbf{2 f}$

\section{The modification of model peptide $\mathbf{1 a}$ with benzylhydrazine $\mathbf{2 g}$}

The peptide 1a (1 $\mu \mathrm{mol}$ with respect to the selenol monomer $)$ and $\mathrm{CuSO}_{4}(1 \mu \mathrm{mol})$ dissolved in 700 $\mu \mathrm{L}$ PB buffer $(10 \mathrm{mM}, \mathrm{pH} 7)$ was incubated at $37^{\circ} \mathrm{C}$ for $5 \mathrm{~min} .2 \mathrm{~g}(2 \mu \mathrm{mol})$ dissolved in $300 \mu \mathrm{L} \mathrm{PB}$ buffer $(10 \mathrm{mM}, \mathrm{pH} 6)$ was incubated at $37{ }^{\circ} \mathrm{C}$ for $5 \mathrm{~min}$ and then added dropwise to the above reaction solution. The reaction mixture was incubated at $37{ }^{\circ} \mathrm{C}$, and the reaction progress was monitored by HPLC (using XSelect C18 column $(3.5 \mu \mathrm{m}, 130 \AA, 4.6 \times 150 \mathrm{~mm})$ with a gradient of 
$5 \%$ B over $5 \mathrm{~min}$ then $5-70 \%$ B over $20 \mathrm{~min}$ at $220 \mathrm{~nm}$ ) and LC-MS. After $1 \mathrm{~h}$, the product $3 \mathrm{~g}$ was isolated in $77 \%$ yield. The product was characterized by ESI-MS $\left([\mathrm{M}+\mathrm{H}]^{+}\right.$obs. 692.17 , calc. 692.27 , Fig. S10).

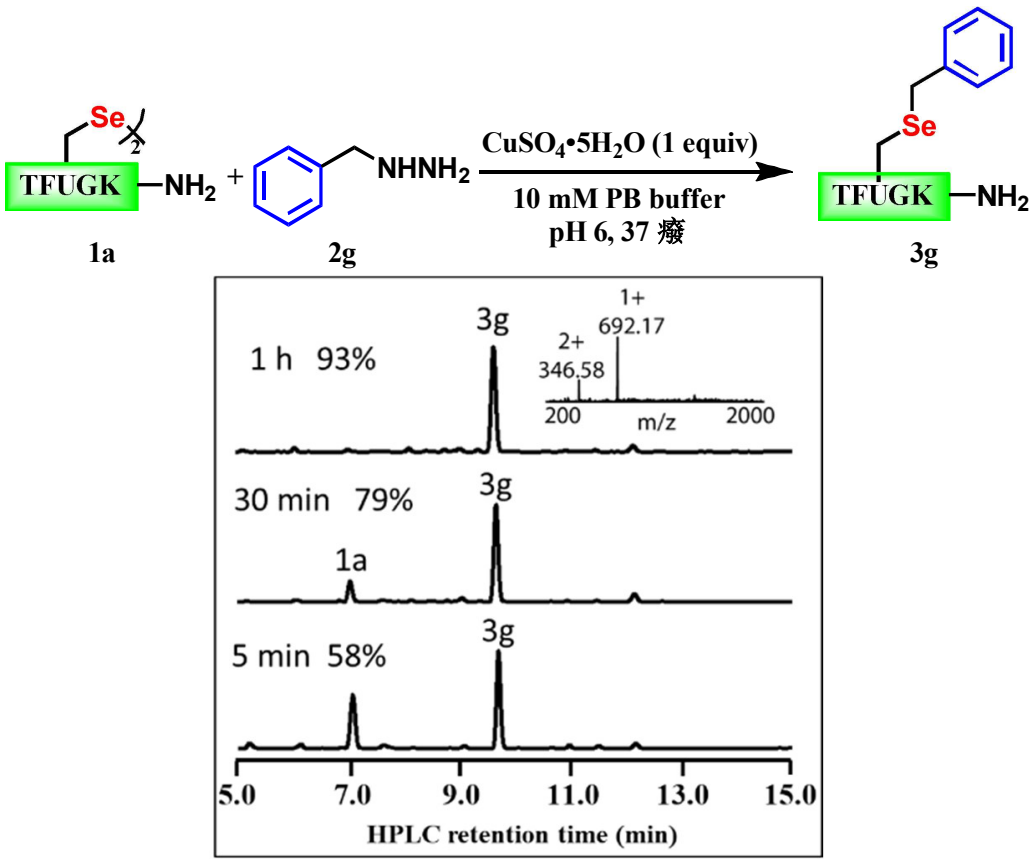

Figure S10. The modification of model peptide $\mathbf{1 a}$ with benzylhydrazine $\mathbf{2 g}$

\section{The modification of model peptide $\mathbf{1 a}$ with isobutylhydrazine $\mathbf{2 h}$}

The peptide $1 \mathrm{a}(1 \mu \mathrm{mol}$ with respect to the selenol monomer $)$ and $\mathrm{CuSO}_{4}(1 \mu \mathrm{mol})$ dissolved in $700 \mu \mathrm{L}$ PB buffer $(10 \mathrm{mM}, \mathrm{pH} 7)$ was incubated at $37{ }^{\circ} \mathrm{C}$ for $5 \mathrm{~min} . \mathbf{2} \mathbf{h}(2 \mu \mathrm{mol})$ dissolved in $300 \mu \mathrm{L}$ PB buffer $\left(10 \mathrm{mM}, \mathrm{pH}\right.$ 6) was incubated at $37^{\circ} \mathrm{C}$ for $5 \mathrm{~min}$ and then added dropwise to the above reaction solution. The reaction mixture was incubated at $37{ }^{\circ} \mathrm{C}$, and the reaction progress was monitored by HPLC (using XSelect C18 column $(3.5 \mu \mathrm{m}, 130 \AA, 4.6 \times 150 \mathrm{~mm}$ ) with a gradient of $5 \%$ B over 5 min then $5-70 \%$ B over $20 \mathrm{~min}$ at $220 \mathrm{~nm}$ ) and LC-MS. After 1 $\mathrm{h}$, the product $\mathbf{3 h}$ was isolated in $36 \%$ yield. The Se-isobutyl-containing product was characterized by ESI-MS ([M + H ${ }^{+}$obs. 658.25 , calc. 658.28$)$ and NMR. ${ }^{1} \mathrm{H}$ NMR (400 MHz, $\left.\mathrm{D}_{2} \mathrm{O}\right) \delta$ 7.32-7.21 (m, 5H), $4.65(\mathrm{t}, \mathrm{J}=7.56 \mathrm{~Hz}, 1 \mathrm{H}), 4.42-4.39(\mathrm{~m}, 1 \mathrm{H}), 4.27-4.23(\mathrm{~m}, 1 \mathrm{H}), 4.08-$ $4.01(\mathrm{~m}, 1 \mathrm{H}), 3.81(\mathrm{~d}, \mathrm{~J}=2.73 \mathrm{~Hz}, 2 \mathrm{H}), 3.76(\mathrm{~d}, \mathrm{~J}=6.61 \mathrm{~Hz}, 1 \mathrm{H}), 3.04-3.02(\mathrm{~m}, 2 \mathrm{H}), 2.92(\mathrm{t}, \mathrm{J}$ $=7.53 \mathrm{~Hz}, 2 \mathrm{H}), 2.86-2.81(\mathrm{~m}, 1 \mathrm{H}), 2.73-2.68(\mathrm{~m}, 1 \mathrm{H}), 2.49-2.47(\mathrm{~m}, 2 \mathrm{H}), 1.85-1.57(\mathrm{~m}, 5 \mathrm{H})$, $1.45-1.32(\mathrm{~m}, 2 \mathrm{H}), 1.22(\mathrm{~d}, \mathrm{~J}=6.50 \mathrm{~Hz}, 3 \mathrm{H}), 0.89(\mathrm{~d}, \mathrm{~J}=6.6 \mathrm{~Hz}, 6 \mathrm{H})$. The results are shown in Fig. S11.

(a)

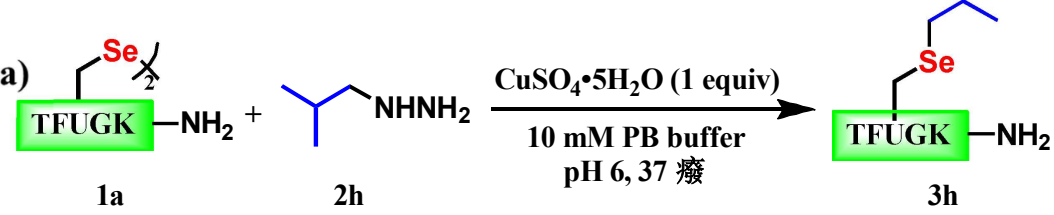



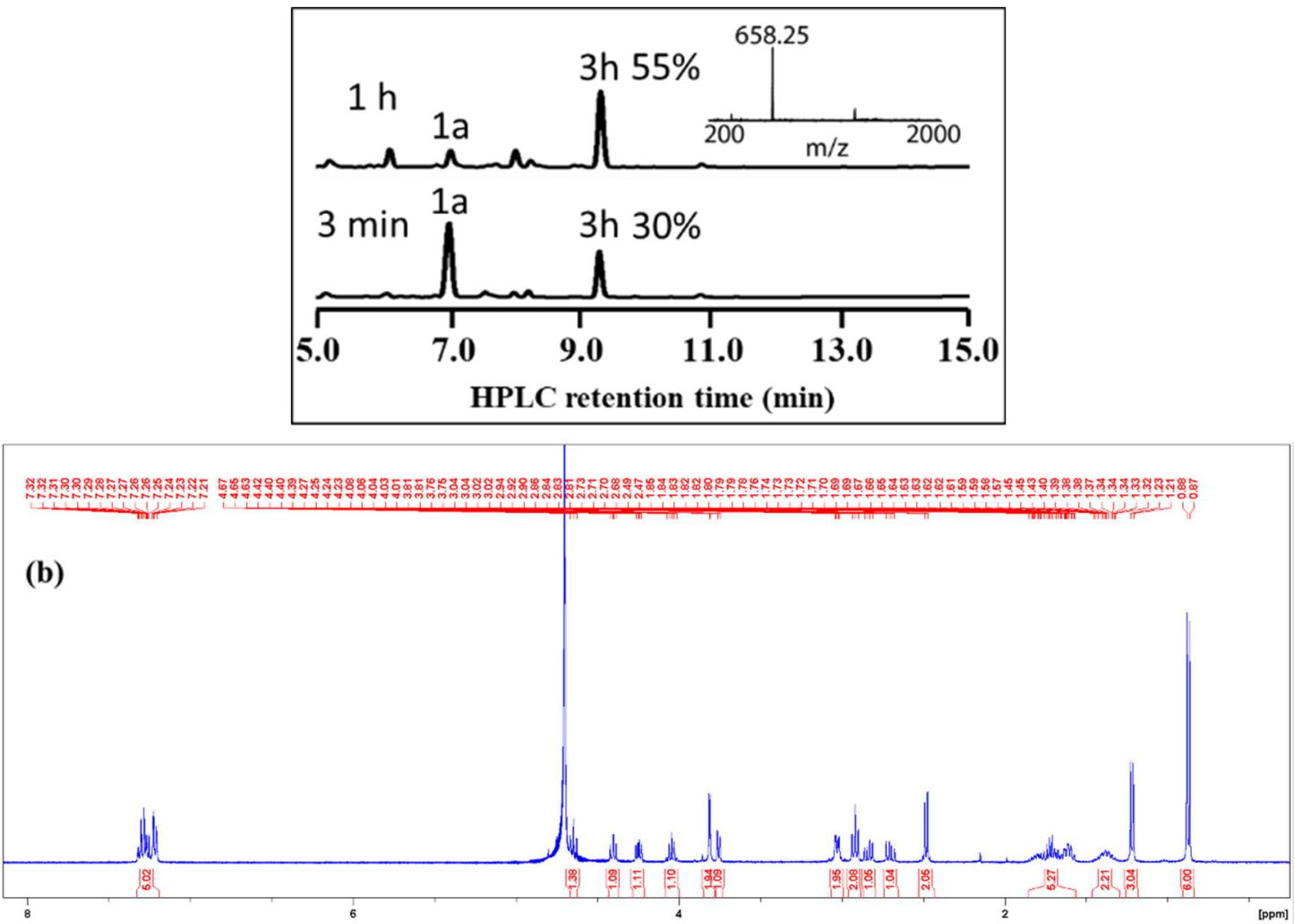

Figure S11. (a) The modification of model peptide 1a with isobutylhydrazine $\mathbf{2 h}$. (b) The ${ }^{1} \mathrm{H}-$ NMR spectrum of the product $\mathbf{3 h}$.

\section{The modification of model peptide $1 \mathbf{a}$ with isopropylhydrazine $\mathbf{2} \boldsymbol{i}$}

The peptide $1 \mathrm{a}$ ( $1 \mu \mathrm{mol}$ with respect to the selenol monomer) and $\mathrm{CuSO}_{4}(1 \mu \mathrm{mol})$ dissolved in $700 \mu \mathrm{L}$ PB buffer (10 mM, pH 7) was incubated at $37^{\circ} \mathrm{C}$ for $5 \mathrm{~min} .2 \mathbf{i}(2 \mu \mathrm{mol})$ dissolved in 300 $\mu \mathrm{L}$ PB buffer (10 mM, pH 6) was incubated at $37^{\circ} \mathrm{C}$ for $5 \mathrm{~min}$ and then added dropwise to the above reaction solution. The reaction mixture was incubated at $37^{\circ} \mathrm{C}$, and the reaction progress was monitored by HPLC (using XSelect C18 column $(3.5 \mu \mathrm{m}, 130 \AA$, $4.6 \times 150 \mathrm{~mm}$ ) with a gradient of $5 \% \mathrm{~B}$ over $5 \mathrm{~min}$ then $5-70 \% \mathrm{~B}$ over $20 \mathrm{~min}$ at $220 \mathrm{~nm}$ ) and LC-MS. After $2 \mathrm{~h}$, the product $3 \mathbf{i}$ was isolated in $56 \%$ yield. The product was characterized by ESI-MS $\left([\mathrm{M}+\mathrm{H}]^{+}\right.$obs. 644.25, calc. 644.27 , a disubstituted side-product was also observed at 6 min retention time: $[\mathrm{M}]^{+}$obs. 686.08, calc. 686.31, Fig. S12).

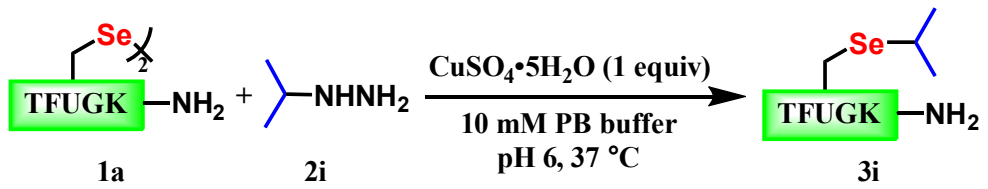




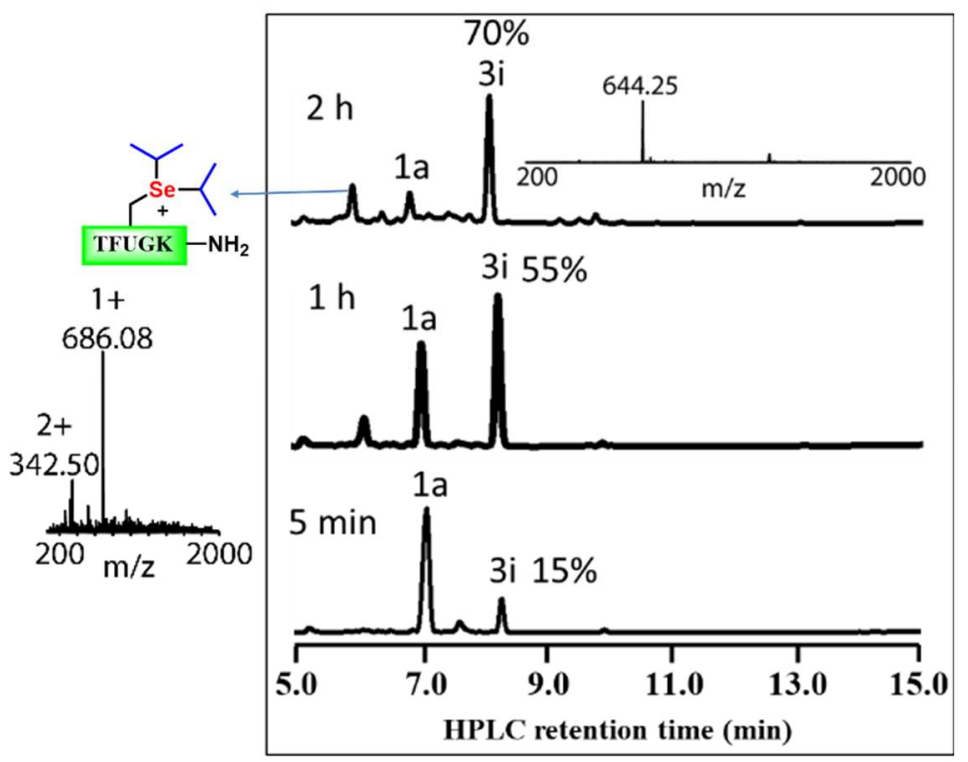

Figure S12. The modification of model peptide 1a with isopropylhydrazine $\mathbf{2 i}$

\section{The modification of model peptide $\mathbf{1} \boldsymbol{a}$ with tert-butylhydrazine $\mathbf{2} \boldsymbol{j}$}

The peptide 1a (1 $\mu \mathrm{mol}$ with respect to the selenol monomer) and $\mathrm{CuSO}_{4}(1 \mu \mathrm{mol})$ dissolved in $700 \mu \mathrm{L}$ PB buffer $(10 \mathrm{mM}, \mathrm{pH} 7)$ was incubated at $37{ }^{\circ} \mathrm{C}$ for $5 \mathrm{~min} .2 \mathbf{j}(2 \mu \mathrm{mol})$ dissolved in $300 \mu \mathrm{L}$ PB buffer $\left(10 \mathrm{mM}, \mathrm{pH}\right.$ 6) was incubated at $37^{\circ} \mathrm{C}$ for $5 \mathrm{~min}$ and then added dropwise to the above reaction solution. The reaction mixture was incubated at $37{ }^{\circ} \mathrm{C}$, and the progress was monitored by HPLC (using XSelect C18 column $(3.5 \mu \mathrm{m}, 130 \AA, 4.6 \times 150 \mathrm{~mm})$ with a gradient of $5 \% \mathrm{~B}$ over $5 \mathrm{~min}$ then $5-70 \% \mathrm{~B}$ over $20 \mathrm{~min}$ at $220 \mathrm{~nm}$ ) and LC-MS. After $2 \mathrm{~h}$, the product $3 \mathbf{j}$ was isolated in $30 \%$ yield. The product was characterized by ESI-MS $\left([\mathrm{M}+\mathrm{H}]^{+}\right.$obs. 658.25 , calc. 658.28) and NMR. ${ }^{1} \mathrm{H}$ NMR $\left(400 \mathrm{MHz}, \mathrm{D}_{2} \mathrm{O}\right) \delta$ 7.32-7.21 (m, 5H), $4.64(\mathrm{t}, \mathrm{J}=7.57 \mathrm{~Hz}$, $1 \mathrm{H}), 4.43(\mathrm{t}, \mathrm{J}=7.42 \mathrm{~Hz}, 1 \mathrm{H}), 4.27-4.23(\mathrm{~m}, 1 \mathrm{H}), 4.08-4.01(\mathrm{~m}, 1 \mathrm{H}), 3.80(\mathrm{~m}, 2 \mathrm{H}), 3.75(\mathrm{~d}, \mathrm{~J}=$ $6.54 \mathrm{~Hz}, 1 \mathrm{H}), 3.08-2.97(\mathrm{~m}, 2 \mathrm{H}), 2.94-2.88(\mathrm{~m}, 3 \mathrm{H}), 2.77-2.72(\mathrm{~m}, 1 \mathrm{H}), 1.86-1.58(\mathrm{~m}, 4 \mathrm{H}), 1.36-$ $1.33(\mathrm{~m}, 11 \mathrm{H}), 1.22(\mathrm{~d}, \mathrm{~J}=6.40 \mathrm{~Hz}, 3 \mathrm{H})$. The results are shown in Fig. S13. \# is the side-product formed, which has a mass of $+15 \mathrm{Da}$ of the 1a monomer (monomer mass calc. 601.21 Da, obs. mass [M+15] 616.25), which may indicate Sec was oxidized.

(a)

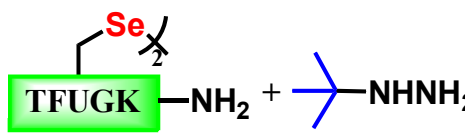

1a

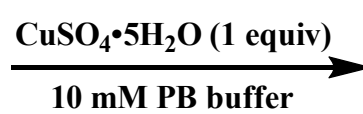

pH 6, rt

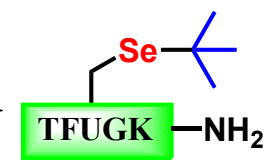

$3 \mathbf{j}$ 

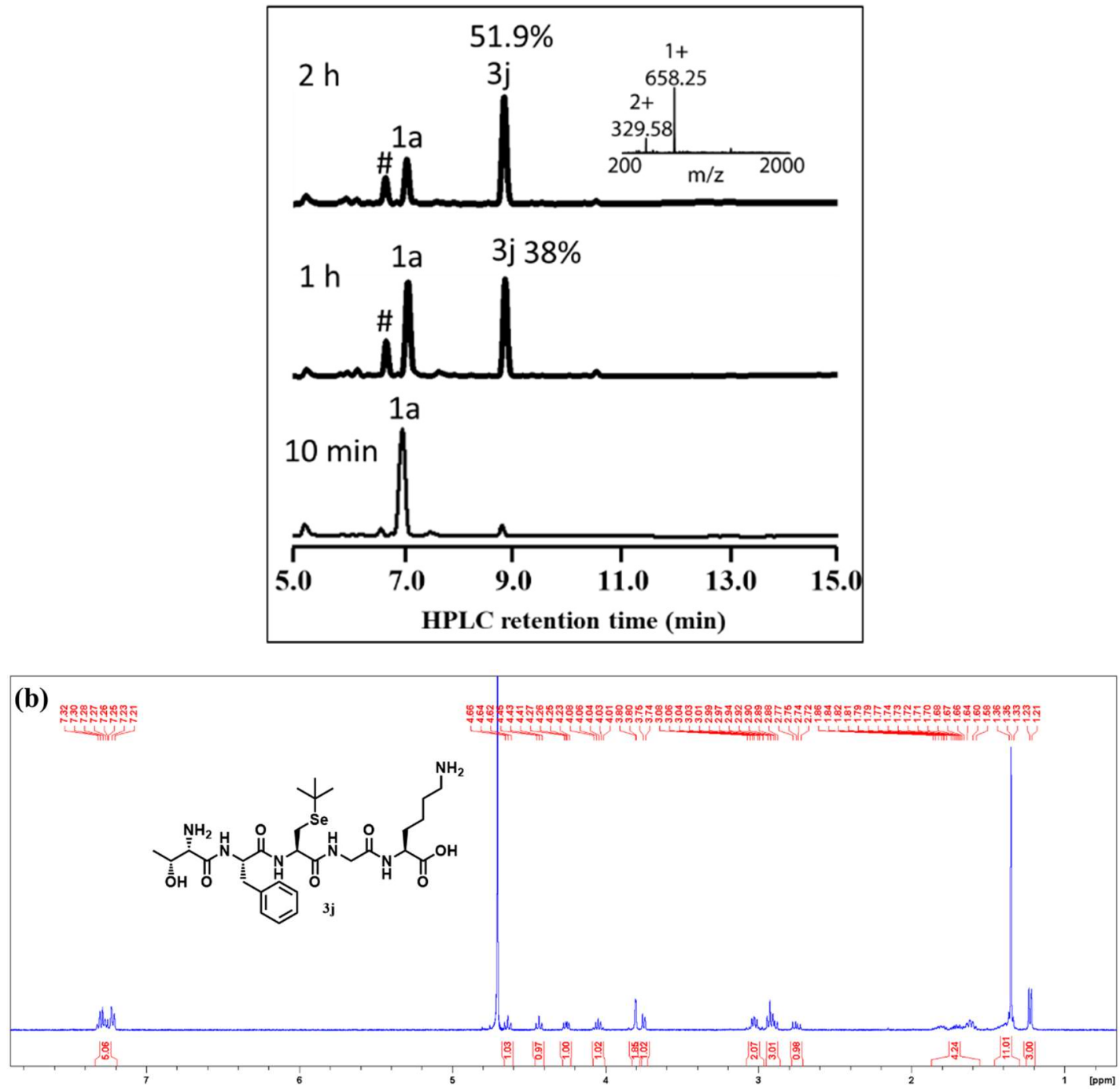

Figure S13. (a) The modification of model peptide 1a with tert-butylhydrazine 2j. (b) The ${ }^{1} \mathrm{H}-\mathrm{NMR}$ spectrum of $\mathbf{3 j}$

\section{The modification of model peptide $\mathbf{1 a}$ with (cyclopropylmethyl)hydrazine $\mathbf{2} \boldsymbol{k}$}

The peptide 1a (1 $\mu \mathrm{mol}$ with respect to the selenol monomer) and $\mathrm{CuSO}_{4}(1 \mu \mathrm{mol})$ dissolved in $700 \mu \mathrm{L}$ PB buffer $(10 \mathrm{mM}, \mathrm{pH} 7)$ was incubated at $37{ }^{\circ} \mathrm{C}$ for $5 \mathrm{~min} .2 \mathbf{k}(2 \mu \mathrm{mol})$ dissolved in $300 \mu \mathrm{L}$ PB buffer $(10 \mathrm{mM}, \mathrm{pH} 6)$ was incubated at $37^{\circ} \mathrm{C}$ for $5 \mathrm{~min}$ and then added dropwise to the above reaction solution. The reaction mixture was incubated at $37{ }^{\circ} \mathrm{C}$, and the progress was monitored by HPLC (using XSelect C18 column $(3.5 \mu \mathrm{m}, 130 \AA, 4.6 \times 150 \mathrm{~mm})$ with a gradient of $5 \%$ B over $5 \mathrm{~min}$ then $5-70 \%$ B over $20 \mathrm{~min}$ at $220 \mathrm{~nm}$ ) and LC-MS. After $2 \mathrm{~h}$, the product $3 \mathbf{k}$ was isolated in $52 \%$ yield. The product was characterized by ESI-MS $\left([\mathrm{M}+\mathrm{H}]^{+}\right.$obs. 656.08 , calc. 656.27) and NMR. A dehydroalanine side-product: $[\mathrm{M}+\mathrm{H}]^{+}$obs. 520.08, calc. 520.29; and a deselenization side-product: $[\mathrm{M}+\mathrm{H}]^{+}$obs. 522.08, calc. 522.30; a disubstituted product, \#: obs. 709.92 , calc. 710.31 were observed at low amounts. The product 3k ${ }^{1} \mathrm{H}$ NMR $\left(400 \mathrm{MHz}, \mathrm{D}_{2} \mathrm{O}\right)$ 反 7.32-7.25 (m, 3H), 7.23-7.21 (m, 2H), 5.82-5.72 (m, 1H), 5.06-4.97 (m, 2H), $4.64(\mathrm{t}, \mathrm{J}=7.83$ $\mathrm{Hz}, 1 \mathrm{H}), 4.43(\mathrm{t}, \mathrm{J}=7.08 \mathrm{~Hz}, 1 \mathrm{H}), 4.26-4.22(\mathrm{~m}, 1 \mathrm{H}), 4.08-4.02(\mathrm{~m}, 1 \mathrm{H}), 3.81-3.77(\mathrm{~m}, 3 \mathrm{H})$, 3.04-3.01 (m, 2H), 2.94-2.84 (m, 3H), 2.75-2.70 (m, 1H), $2.62(\mathrm{t}, \mathrm{J}=7.26 \mathrm{~Hz}, 2 \mathrm{H}), 2.36-2.31$ $(\mathrm{q}, \mathrm{J}=7.08 \mathrm{~Hz}, 2 \mathrm{H}), 1.85-1.76(\mathrm{~m}, 1 \mathrm{H}), 1.72-1.57(\mathrm{~m}, 3 \mathrm{H}), 1.43-1.33(\mathrm{~m}, 2 \mathrm{H}), 1.22(\mathrm{~d}, \mathrm{~J}=6.36$ 
Hz, 3H). The results are shown in Fig. S14.

(a)

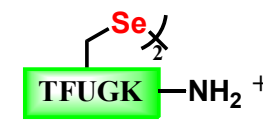

$1 \mathbf{a}$

$2 \mathbf{k}$

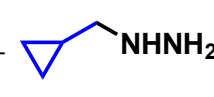

$\mathrm{CuSO}_{4} \cdot 5 \mathrm{H}_{2} \mathrm{O}$ (1 equiv)

$10 \mathrm{mM}$ PB buffer

pH 6, rt
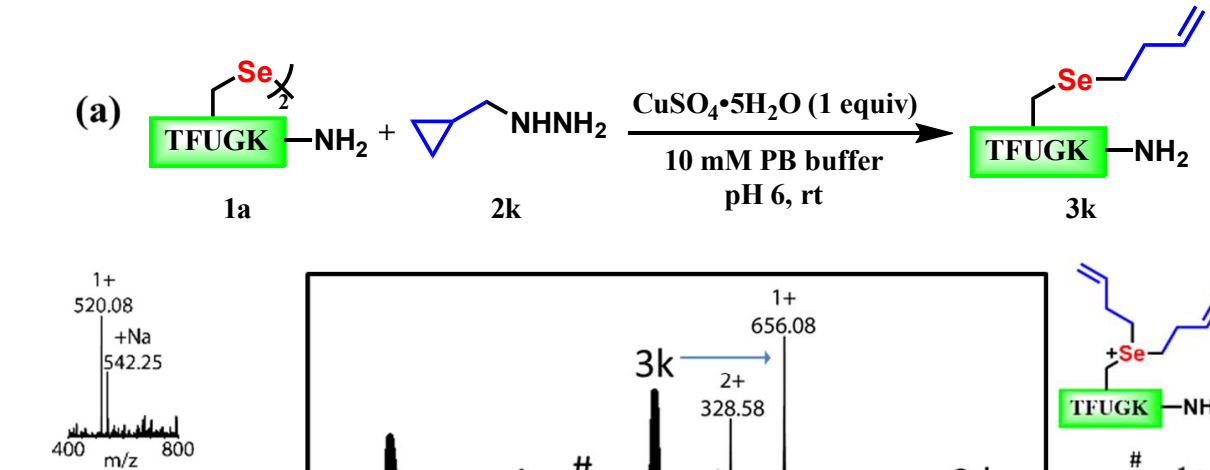

TF

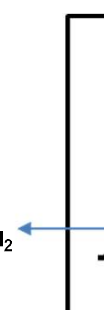
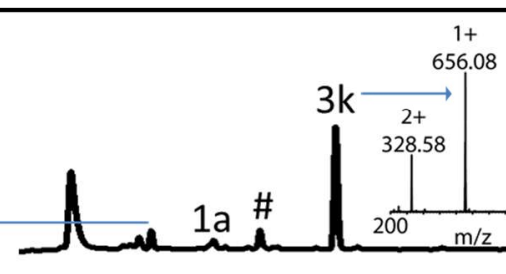

$1+$
656.08
+

$\int^{2+}+328.58$
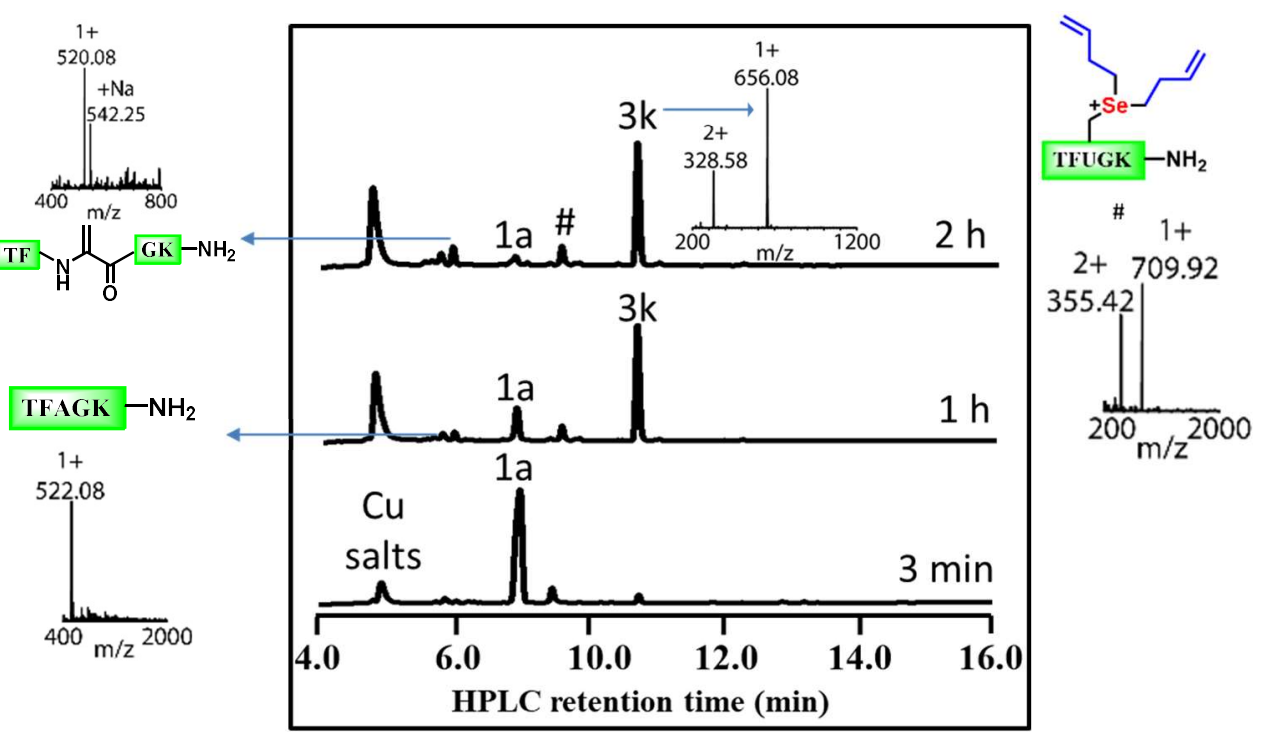

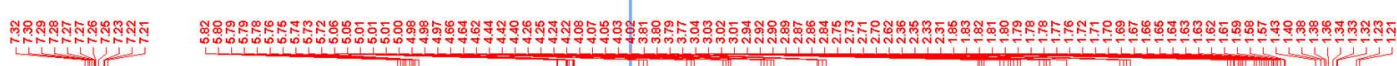

(b)

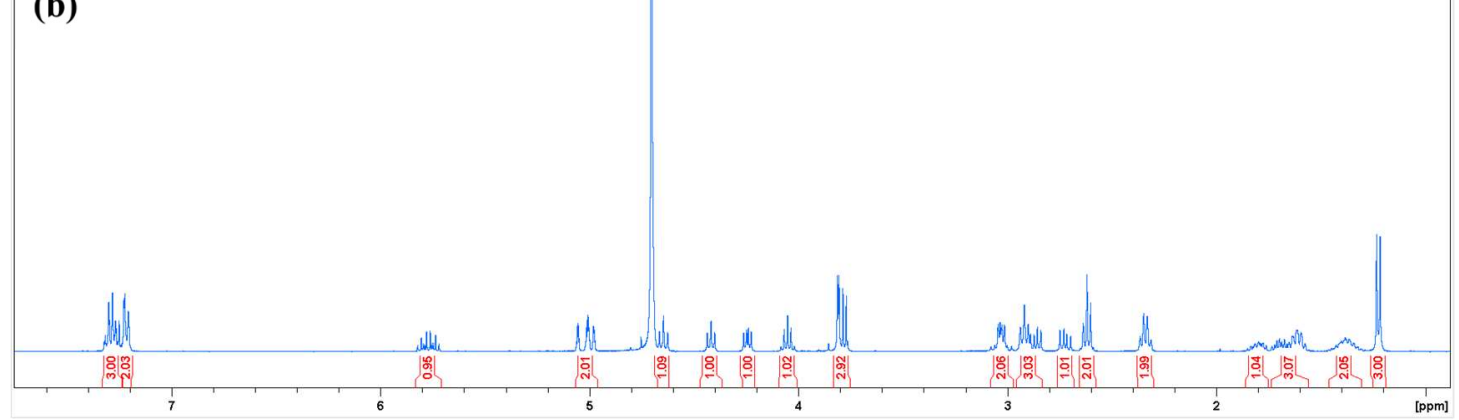

Figure S14. (a) The modification of model peptide 1a with (cyclopropylmethyl)hydrazine $\mathbf{2 k}$. (b) The ${ }^{1} \mathrm{H}-\mathrm{NMR}$ Spectrum of $\mathbf{3 k}$.

\section{The modification of model peptide $1 \mathbf{a}$ with biotin-containing phenylhydrazine $\mathbf{2 l}$}

The peptide 1a $(1 \mu \mathrm{mol}$ with respect to the selenol monomer $)$ and $\mathrm{CuSO}_{4}(1 \mu \mathrm{mol})$ dissolved in 700 $\mu \mathrm{L}$ PB buffer (10 mM, pH 7) was incubated at $37^{\circ} \mathrm{C}$ for $5 \mathrm{~min} .2 \mathbf{2}(2 \mu \mathrm{mol})$ dissolved in $300 \mu \mathrm{L}$ PB buffer $\left(10 \mathrm{mM}, \mathrm{pH}\right.$ 6) was incubated at $37^{\circ} \mathrm{C}$ for $5 \mathrm{~min}$ and then added dropwise to the above reaction solution. The reaction mixture was incubated at $37{ }^{\circ} \mathrm{C}$, and the reaction progress was monitored by HPLC (using XSelect C18 column $(3.5 \mu \mathrm{m}, 130 \AA, 4.6 \times 150 \mathrm{~mm})$ with a gradient of $5 \% \mathrm{~B}$ over $5 \mathrm{~min}$ then $5-70 \% \mathrm{~B}$ over $20 \mathrm{~min}$ at $220 \mathrm{~nm}$ ) and LC-MS. After $2 \mathrm{~h}$, the product $3 \mathrm{I}$ was isolated in $80 \%$ yield. The product was characterized by ESI-MS $\left([\mathrm{M}+\mathrm{H}]^{+}\right.$obs. 990.33 , calc. 990.38 , Fig. S15, *, \# and \#\# are side-products from 21 ). 


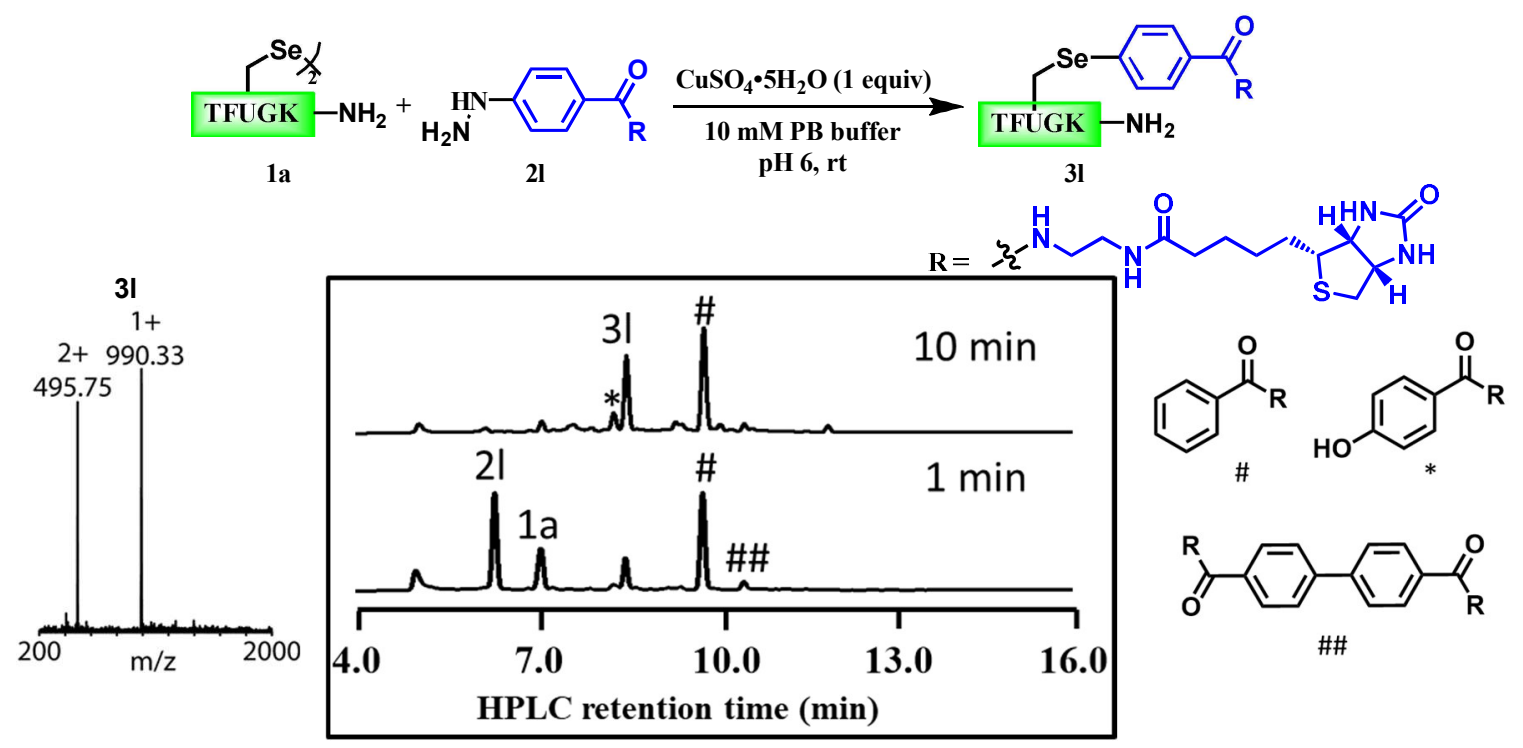

Figure S15. The modification of model peptide 1a with biotin-containing phenylhydrazine $\mathbf{2 l}$

\section{EPR experiments}

For CW-EPR spectra of the DMPO spin adducts, the experimental conditions were: room temperature, modulation frequency $100 \mathrm{kHz}$, modulation amplitude $1 \mathrm{G}$, receiver gain $2 \cdot 10^{5}$, conversion time $49 \mathrm{~ms}$, central field $3307 \mathrm{G}$, scan width $150 \mathrm{G}, 2048$ points. For CW-EPR spectra of the copper and the DMPO spin adduct, the experimental conditions were: room temperature, modulation frequency $100 \mathrm{kHz}$, modulation amplitude $5 \mathrm{G}$, receiver gain $1 \cdot 10^{5}$, conversion time 49 ms, central field $3000 \mathrm{G}$, scan width $1600 \mathrm{G}, 2048$ points. In some cases, noted in the text, the receiver gain was changed.

The DMPO spin adduct spectra were fitted using EasySpin. ${ }^{3}$ The best fit for the DMPO-Ph line was obtained using: a g-factor of $\mathrm{g}=2.00552$, e-N hyperfine interaction of $\mathrm{a}_{\mathrm{N}}=15.9227 \mathrm{G}$ and e-H hyperfine interaction of $\mathrm{a}_{\mathrm{H}}=24.6433 \mathrm{G}$, and Lorentzian line broadening of $0.6 \mathrm{G}$. The best fit for the spin adducts lines formed with $\mathrm{Cu}$ was obtained using: 1) $\mathrm{g}=2.00552, \mathrm{a}_{\mathrm{N}}=15.0468 \mathrm{G}, \mathrm{a}_{\mathrm{H}}=14.8580$ $\mathrm{G}$, and Lorentzian line broadening of 0.6 G. 2) $\mathrm{g}=2.00552, \mathrm{a}_{\mathrm{N}}=15.6026 \mathrm{G}, \mathrm{a}_{\mathrm{N}}=23.1094 \mathrm{G}$, and Lorentzian line broadening of 0.6 G. 2) $g=2.00552, \mathrm{a}_{\mathrm{N}}=16.4394 \mathrm{G}, \mathrm{a}_{\mathrm{H}}=22.7094 \mathrm{G}$, and Lorentzian line broadening of $0.6 \mathrm{G}$.

DMPO for EPR spectroscopy was purchased from Sigma-Aldrich, and used without further

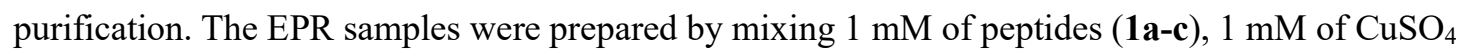
and $1 \mathrm{mM}$ of phenylhydrazine (2c). A final concentration of $20 \mathrm{mM}$ of DMPO was used in all cases. DMPO was added last to each sample, unless otherwise specified.

As a first test of the EPR system, we recorded the line of $\mathrm{Cu}^{2+}$, shown in Fig. S16. 


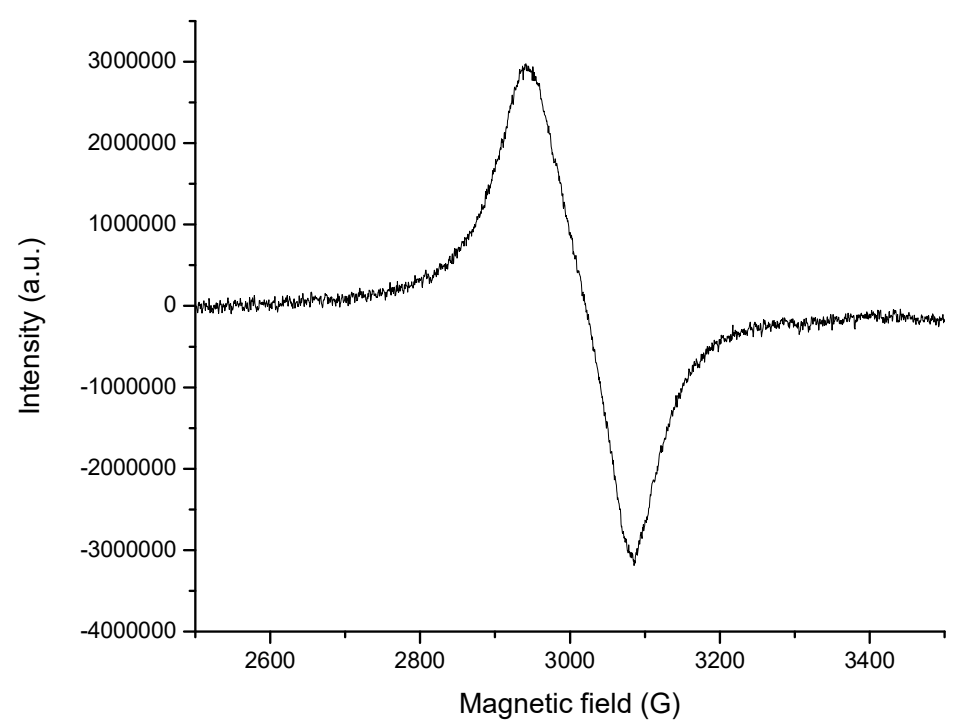

Figure S16. CW-EPR line of $\mathrm{Cu}$ (II) in solution. The $\mathrm{g}$-factor of the $\mathrm{Cu}$ is $\mathrm{g}=2.19$. The spectrum was recorded in 10 scans.
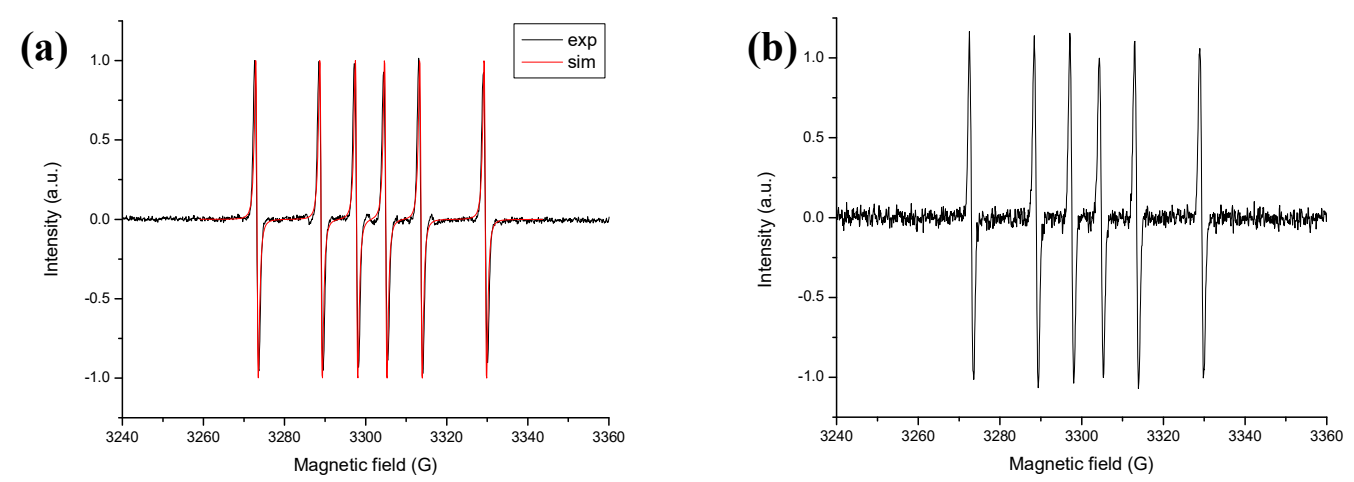

Figure S17. EPR spectrum of DMPO-Ph spin adduct: (a) formed during the reaction of peptide TFUGK, $2 \mathbf{c}$ and $\mathrm{CuSO}_{4}$, with a ratio of 1:2:1, 10 scans (black), overlaid with a simulated spectrum 1 scan (red); (b) formed during the reaction of $\mathbf{2 c}$ and $\mathrm{CuSO}_{4}$, with a ratio of 2:1 The best fit was obtained using: a g-factor of $\mathrm{g}=2.00552$, e-N hyperfine interaction of $\mathrm{a}_{\mathrm{N}}=15.9227 \mathrm{G}$ and e- $\mathrm{H}$ hyperfine interaction of $\mathrm{a}_{\mathrm{H}}=24.6433 \mathrm{G}$, and Lorentzian line broadening of $0.6 \mathrm{G}$.

Next, we added DMPO to $\mathrm{CuSO}_{4}$, and a spin adduct signal appeared. The spectrum consisted of 15 lines, which we were able to fit using three types of spin adducts, based on the work of Yoshioka et.

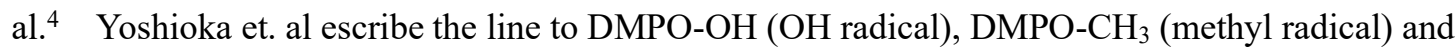
DMPO-H (H radical), where the methyl spin adduct is formed via a reaction of the $\mathrm{OH}$ radical with DMSO used in the solvent. However, in our work, we do not use DMSO. Walger et. al, also recorded a similar EPR line for $\mathrm{CuSO}_{4}$ with DMSO. They attribute the EPR line to DMPO-OH (OH radical), DMPO-R (carbon radical) and what they termed the "triplet radical". They attribute the carbon radical and the "triplet radical" to decomposition of DMPO itself, which is likely to occur in our 
sample as well. When phenylhyradzine was present in the sample, signals from these spin adducts were not observed. The intensity of these signals was much lower than that of the DMPO-Ph spin adduct, and disappeared within minutes.

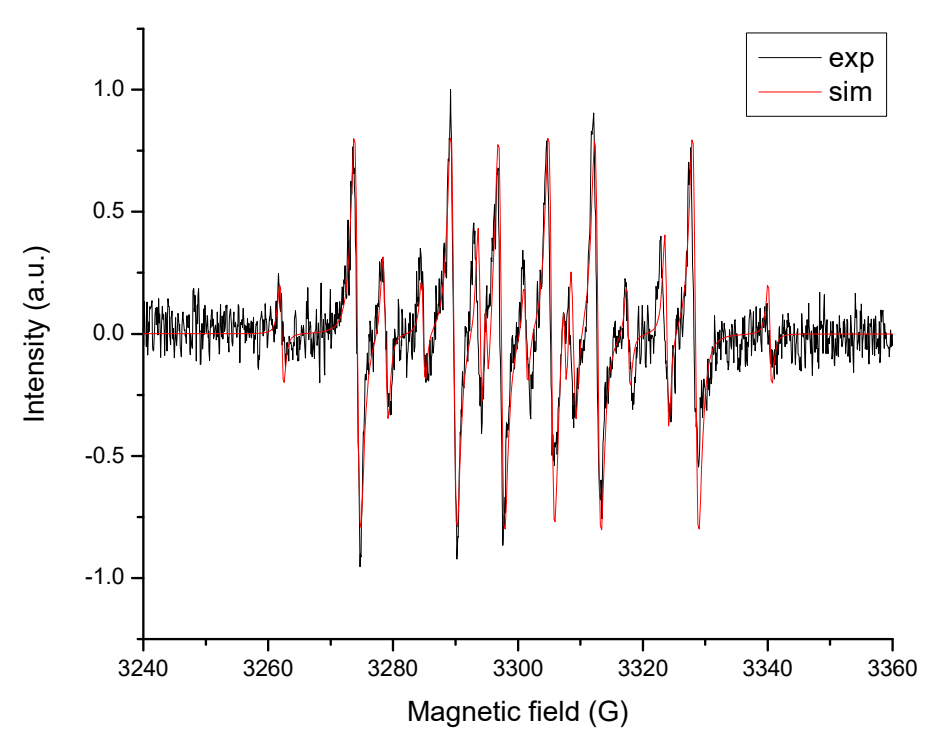

Figure S18. CW-EPR spectrum of spin adducts formed when we added DMPO to $\mathrm{CuSO}_{4}$ (black), overlaid with a simulated spectrum (red). The best fit was obtained using: 1) $\mathrm{g}=2.00552, \mathrm{a}_{\mathrm{N}}=15.0468$ $\mathrm{G}, \mathrm{a}_{\mathrm{H}}=14.8580 \mathrm{G}$, and Lorentzian line broadening of $0.6 \mathrm{G} .2$ ) $\mathrm{g}=2.00552, \mathrm{a}_{\mathrm{N}}=15.6026 \mathrm{G}$, $\mathrm{a}_{\mathrm{H}}=23.1094 \mathrm{G}$, and Lorentzian line broadening of 0.6 G. 2) $\mathrm{g}=2.00552, \mathrm{a}_{\mathrm{N}}=16.4394 \mathrm{G}, \mathrm{a}_{\mathrm{N}}=22.7094$ $\mathrm{G}$, and Lorentzian line broadening of $0.6 \mathrm{G}$. The experimental spectrum was recorded in 10 scans.

The same spin adduct line was seen when peptides TFUGK, LKFCAG, and ALKFAG were mixed with $\mathrm{CuSO}_{4}$ and DMPO. Also, here, the spin adduct line was unstable, and decreased within minutes. However, the starting amplitude (recorded immediately after "auto-tune" completed) varied depending on which peptide was used (Fig. S19). The amplitude of the spin adduct signal was as follows TFUGK $<$ LKFCAG $<$ ALKFAG (The sample sizes were similar, in all cases, allowing us to compare amplitudes). These results suggest that the interaction between the $\mathrm{Se}$ and $\mathrm{Cu}^{2+}$ (in TFUGK), limits the spin adduct formation observed without peptides in Fig. S18. Sulfur (in LKFCAG) interacts more weakly with the $\mathrm{Cu}^{2+}$ and thus only partially limits the spin adduct formation. Whereas when Se and $\mathrm{S}$ are not present (in ALKFAG), the $\mathrm{Cu}^{2+}$ does not interact with the peptide and is able to form the DMPO spin adducts. 


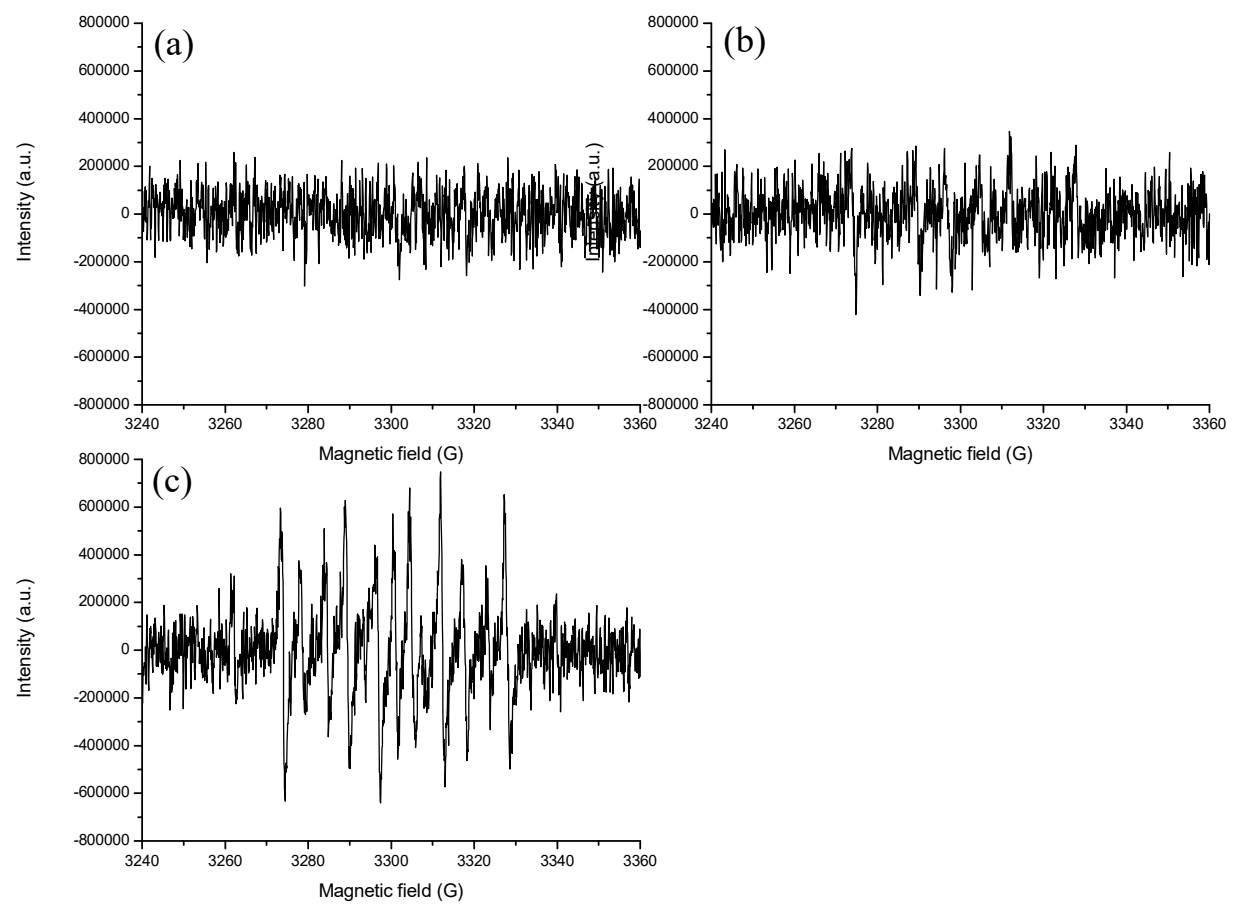

Figure S19. CW-EPR spectra for peptides TFUGK (a), LKFCAG (b) and ALKFAG (c), recorded immediately after "auto-tune" of the EPR spectrometer completed. In all cases, 1 scan was recorded, the experimental settings were identical, and the sample sizes were similar.

Next, we looked at the signal of three different peptides (LKFCAG, ALKFAG and TFUGK), in the presence of $2 \mathbf{c}$ and $\mathrm{CuSO}_{4}$. As can be seen in Fig. S20 in all cases the same DMPO-Ph spin adduct EPR line was recorded. This is the same line shown in the main text and fitted in Fig. S17. Therefore, we can conclude that the peptide does not affect which radical is formed. However, observing the intensities of the DMPO-Ph spin adduct with different peptides, we do see differences (the sample sizes were similar, in all cases, allowing us to compare amplitudes). This was true also when we changed the molar ratio of the peptide, $2 \mathrm{c}$ and $\mathrm{CuSO}_{4}$. Ratios of 1:2:1, 1:1:1 and 1:0.5:1 were explored. For the cases with ratios of 1:2:1 and 1:1:1, no obvious difference of the signal of the DMPO-Ph spin adduct was observed, but for the cases with ratio of 1:0.5:1, the signal of the DMPO$\mathrm{Ph}$ spin adduct was largest with TFUGK (Se containing peptide), then with LKFCAG (S containing peptide), and the smallest was with ALKFAG (does not contain Se or S). These results suggest that the $\mathrm{Ph}$ radical is partially stabilized by the Se, thus increasing the radical lifetime until it is able to react with DMPO and form the DMPO-Ph spin adduct. Sulfur is partially able to stabilize the $\mathrm{Ph}$ radical, whereas when no Se or S are present, the $\mathrm{Ph}$ radical lifetime is very short, due to reactions with water, and other radicals. To check this, compared the signal intensity when DMPO was added last to the signal intensity when $\mathbf{2 c}$ was added last. The signal intensity of the DMPO-Ph spin adduct increased dramatically (approximately 100\%) when $\mathbf{2 c}$ was the last component added in the case of the ALKFAG and LKFCAG. The signal intensity of the DMPO-Ph spin adduct increased much less for TFUGK (approximately 30\%). This strengthens our conclusion that the reason the signal is low 
for ALKFAG and LKFCAG and much higher for TFUGK is because the Se atom in TFUGK is able to stabilize the $\mathrm{Ph}$ radical until it can react with DMPO.
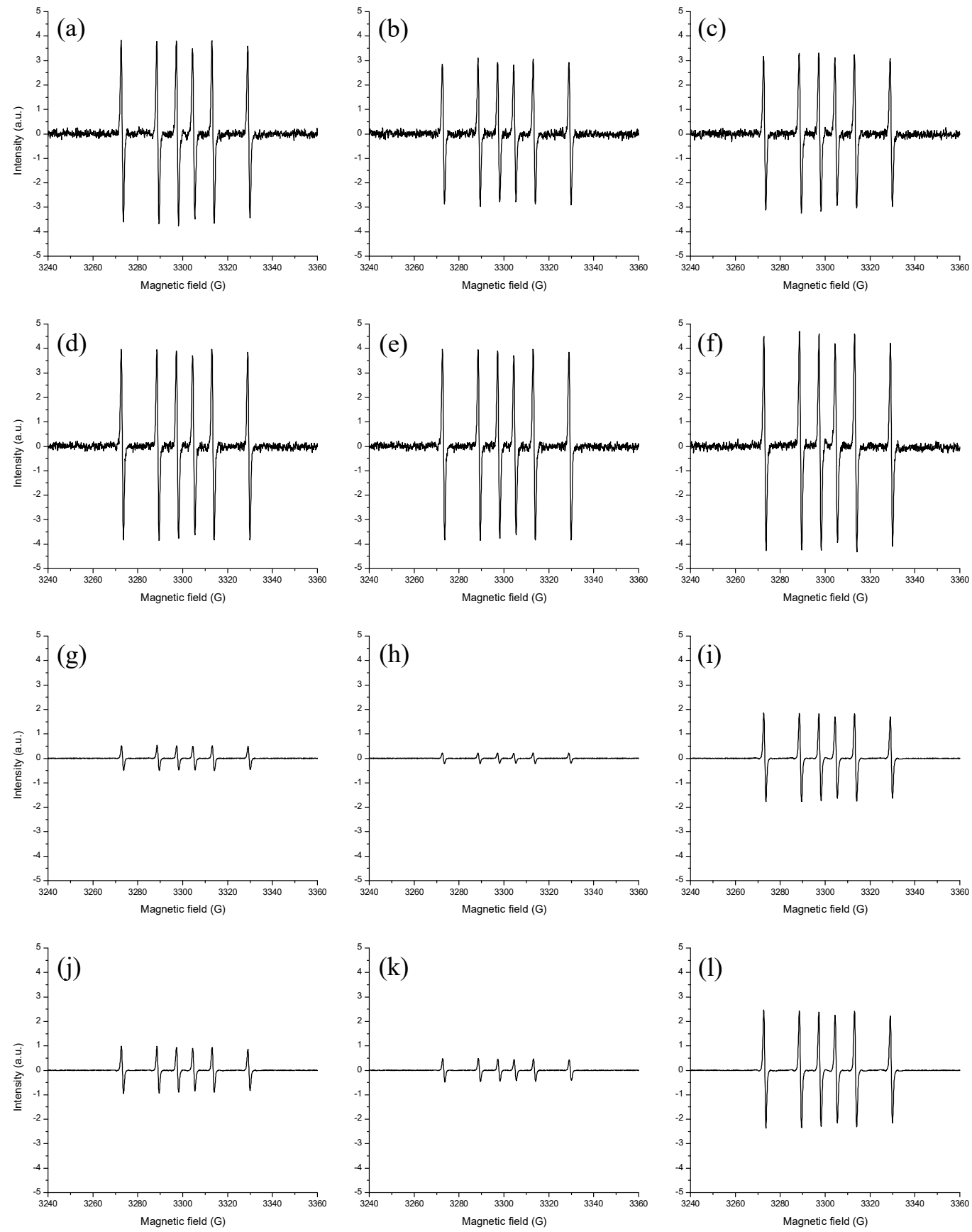

Figure S20. CW-EPR spectra of the DMPO-Ph spin adduct formed during the reaction of a peptide, $2 \mathbf{c}$ and $\mathrm{CuSO}_{4}$, for different ratios of the components. The peptides used were as followed (from left to right): LKFCAG (a, d, g, j), ALKFAG (b, e, h, k) and TFUGK (c, f, i, l). The mole ratios were as followed (first row, and moving down): 1:2:1 (a, b, c), 1:1:1 (d, e, f), 1:0.5:1 (g, h, i) and 1:0.5:1 (j, $\mathrm{k}, 1)$. In the top 3 rows, DMPO was added last to the solution. In the bottom row, $\mathbf{2} \mathbf{c}$ was added last 
to the solution. In all cases the samples were similar in size and conditions. In the top two rows, the receiver gain was set to $2 \cdot 10^{5}$, and in the bottom two rows, to $1 \cdot 10^{4}$.

\section{The study of the chemoselectivity of peptide modification}

To investigate the chemoselectivity of peptide modification by our developed method, we prepared three peptides without Sec residue (Fig. S46, S47, S48): ALKFAG-NH ${ }_{2}$ (1b), LKFCAG-NH 2 (1c), LKMAG-NH 2 (1d). According to general approach for peptide modification, the stock solution of model peptides 1a-1d $(20 \mathrm{mM})$, phenylhydrazine $2 \mathbf{c}(40 \mathrm{mM})$ and $\mathrm{CuSO}_{4}(20 \mathrm{mM})$ were prepared for peptide modification.

1. The reaction of peptide $\mathbf{1 b}$ with phenylhydrazine $2 \boldsymbol{c}$

The peptide $1 \mathbf{b}(1 \mu \mathrm{mol})$ and $\mathrm{CuSO}_{4}(1 \mu \mathrm{mol})$ dissolved in $700 \mu \mathrm{L}$ PB buffer $(10 \mathrm{mM}, \mathrm{pH} 7)$ was incubated at room temperature for $5 \mathrm{~min}$. $2 \mathrm{c}(2 \mu \mathrm{mol})$ dissolved in $300 \mu \mathrm{L}$ PB buffer $(10$ $\mathrm{mM}, \mathrm{pH}$ 6) was then added dropwise to the above reaction mixtures. The reaction mixture was incubated at room temperature, and the reaction progress was monitored by HPLC (using XSelect C18 column $(3.5 \mu \mathrm{m}, 130 \AA, 4.6 \times 150 \mathrm{~mm})$ with a gradient of $5 \%$ B over 5 min then $5-70 \%$ B over $20 \mathrm{~min}$ at $220 \mathrm{~nm}$ ) and LC-MS. No modified peptide was observed even after 1 $\mathrm{h}$ (Fig. S21, * is a side-product from $\mathbf{2 c}$ ).
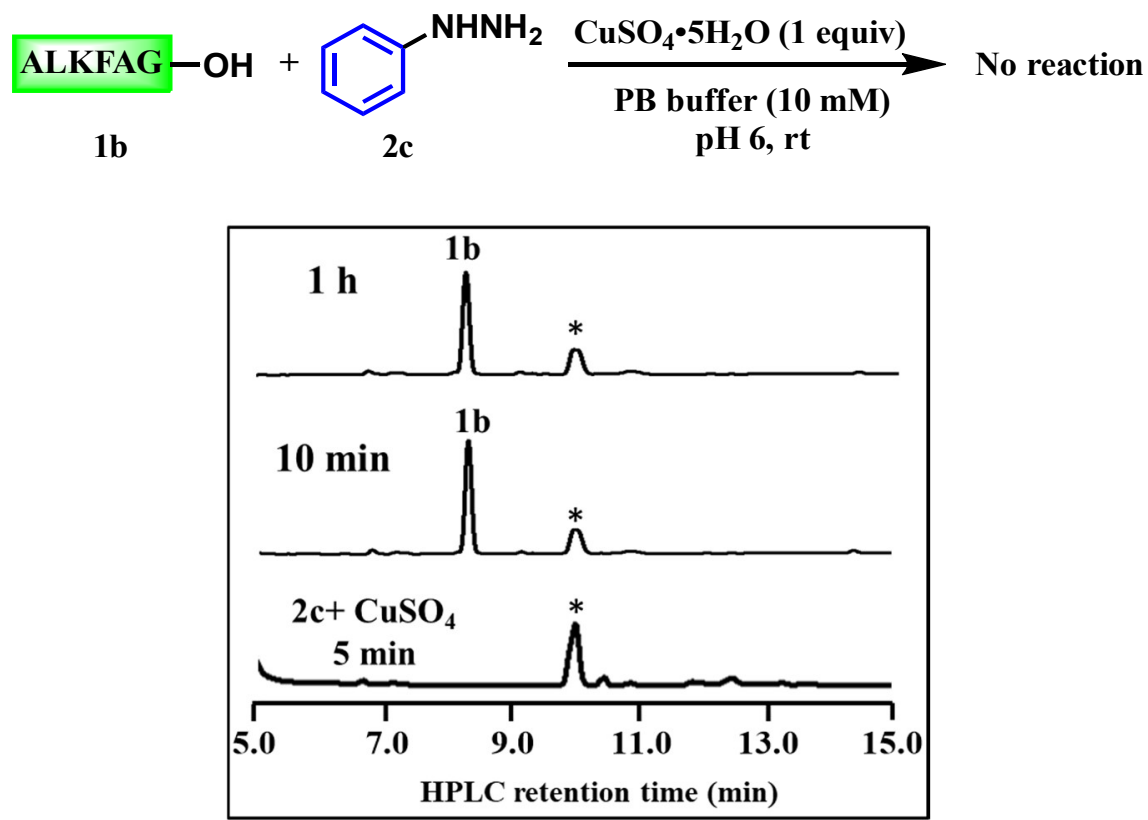

Figure S21. The modification of peptide $\mathbf{1 b}$ with phenylhydrazine $\mathbf{2 c}$. The bottom chromatogram shows the side-product formed by the reaction of phenylhydrazine $\mathbf{2} \mathbf{c}$ and copper ions.

2. The modification of peptide $1 \mathrm{c}$ with phenylhydrazine $\mathbf{2 c}$

The peptide 1c $(1 \mu \mathrm{mol})$ and $\mathrm{CuSO}_{4}(1 \mu \mathrm{mol})$ dissolved in $700 \mu \mathrm{L}$ PB buffer $(10 \mathrm{mM}, \mathrm{pH} 7)$ was incubated at room temperature for $5 \mathrm{~min}$. $2 \mathbf{c}(2 \mu \mathrm{mol})$ dissolved in $300 \mu \mathrm{L}$ PB buffer $(10$ $\mathrm{mM}, \mathrm{pH} 6$ ) and then added dropwise to the above reaction mixtures. The reaction mixture was incubated at room temperature, and the reaction progress was monitored by HPLC (using XSelect C18 column $(3.5 \mu \mathrm{m}, 130 \AA, 4.6 \times 150 \mathrm{~mm})$ with a gradient of $5 \% \mathrm{~B}$ over 5 min then 
$5-70 \%$ B over $20 \mathrm{~min}$ at $220 \mathrm{~nm}$ ) and LC-MS. After $2 \mathrm{~h}$, only $10 \%$ yield of product $4 \mathbf{c}$ was observed. The product was characterized by ESI-MS $\left([\mathrm{M}+\mathrm{H}]^{+}\right.$obs. 713.25, calc. 713.38, Fig. $\mathrm{S} 22, *$ is a side-product from $\mathbf{2 c})$.

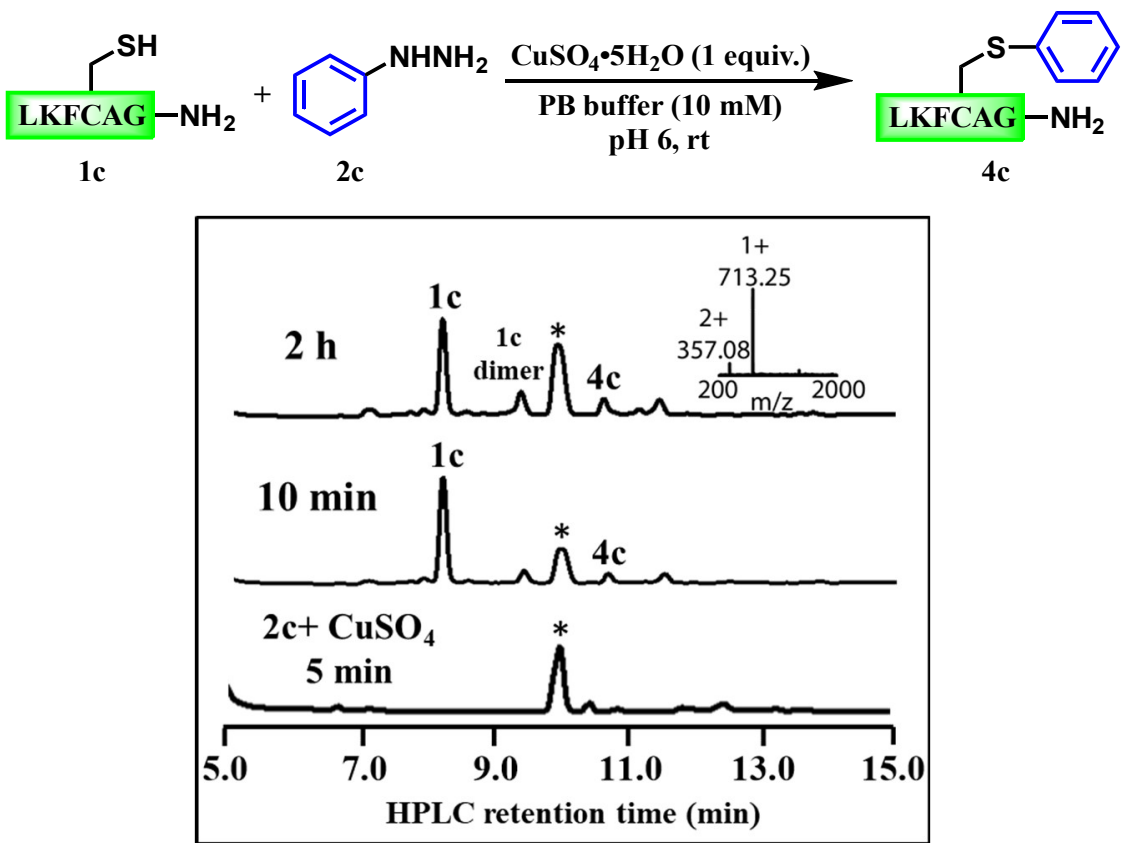

Figure S22. The modification of peptide 1c with phenylhydrazine 2c

3. The modification of peptide $\mathbf{1 d}$ with phenylhydrazine $\mathbf{2 c}$

The peptide $1 \mathrm{~d}(1 \mu \mathrm{mol})$ and $\mathrm{CuSO}_{4}(1 \mu \mathrm{mol})$ dissolved in $700 \mu \mathrm{L}$ PB buffer $(10 \mathrm{mM}, \mathrm{pH} 7)$ and incubated at room temperature for $5 \mathrm{~min}$. $2 \mathrm{c}(2 \mu \mathrm{mol})$ dissolved in $300 \mu \mathrm{L}$ PB buffer $(10$ $\mathrm{mM}, \mathrm{pH}$ 6) was then added dropwise to the above reaction mixtures. The reaction mixture was incubated at room temperature, and the reaction progress was monitored by HPLC (using XSelect C18 column $(3.5 \mu \mathrm{m}, 130 \AA, 4.6 \times 150 \mathrm{~mm})$ with a gradient of $5 \% \mathrm{~B}$ over 5 min then $5-70 \%$ B over $20 \mathrm{~min}$ at $220 \mathrm{~nm}$ ) and LC-MS. After $18 \mathrm{~h}$, only 13\% yield of product $4 \mathbf{d}$ was observed. The product was characterized by ESI-MS $\left([\mathrm{M}+\mathrm{H}]^{+}\right.$obs. 593.92, calc. 594.34, Fig. $\mathrm{S} 23, *$ is a side-product from $\mathbf{2 c}$ ).

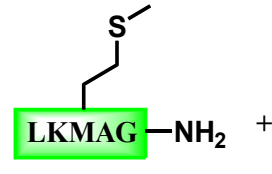

1d<smiles>NNc1ccccc1</smiles>

2c

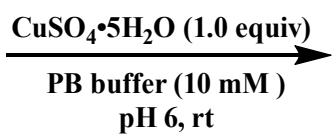

pH 6, rt

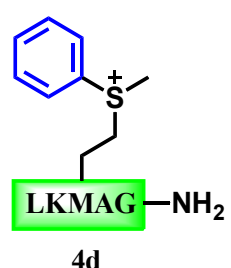

4d 


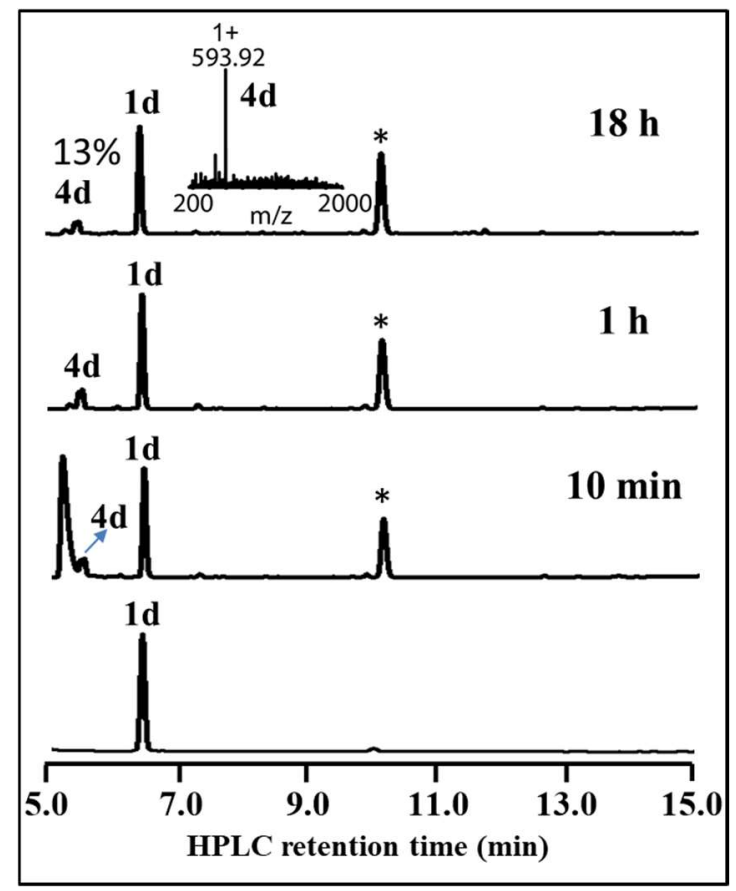

Figure S23. The modification of peptide 1d with phenylhydrazine 2c

\section{The modification of more complex peptides with phenylhydrazine, $2 \mathrm{c}$}

To establish the versatility of this methodology, more complex reaction models should be employed to evaluate in developed protocol. Thus, we prepared two more complex peptides (1e and 1f, Fig. S49 and S50), a cyclic peptide (1g, the synthesis of $\mathbf{1 g}$ was description in reference 5, Fig. S51) and an oxidized TNP-Sec-containing peptide (1h, Fig. S52):

1. VSEFGRGUANKHWCYK-NH $\mathrm{N}_{2}(\mathbf{1 e})$

2. MKFREKSRUKYRWKHRCG-NH $\mathrm{H}_{2}$ (1f)

3. Head-to-tail cyclic peptide c(ULKFAG) (1g)

4. TFU(TNP)GK-NH 2 (1h)

According to general approach for peptide modification, the stock solution of peptides 1e-1h $(20$ $\mathrm{mM})$, phenylhydrazine $2 \mathrm{c}(40 \mathrm{mM})$ and $\mathrm{CuSO}_{4}(20 \mathrm{mM})$ were prepared for peptide modification.

1. The modification of peptide 1e with phenylhydrazine $2 c$

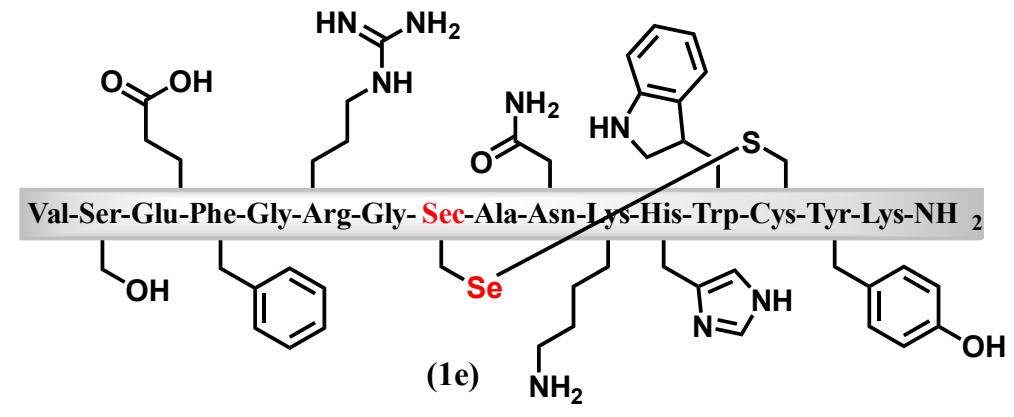

The peptide $1 \mathbf{e}(1 \mu \mathrm{mol})$, containing multiple reactive side-chains in addition to the Sec residue, and $\mathrm{CuSO}_{4}(2 \mu \mathrm{mol})$ dissolved in $700 \mu \mathrm{L}$ PB buffer $(10 \mathrm{mM}, \mathrm{pH}$ 6, adjusted with $0.5 \mathrm{M} \mathrm{NaOH})$ were incubated at room temperature for $5 \mathrm{~min}$. $2 \mathrm{c}(4 \mu \mathrm{mol})$ dissolved in $150 \mu \mathrm{L}$ PB buffer $(10$ $\mathrm{mM}, \mathrm{pH} 6)$ was added dropwise to the above reaction mixture. After 15 minutes, $\mathbf{2 c}(2 \mu \mathrm{mol})$ 
dissolved in $150 \mu \mathrm{L}$ PB buffer ( $10 \mathrm{mM}$, $\mathrm{pH}$ 6) was then added dropwise to the reaction mixture. The reaction mixture was incubated at room temperature, and the reaction progress was monitored by HPLC (using XSelect C18 column $(3.5 \mu \mathrm{m}, 130 \AA, 4.6 \times 150 \mathrm{~mm})$ with a gradient of $5 \%$ B over $5 \mathrm{~min}$ then $5-70 \%$ B over $20 \mathrm{~min}$ at $220 \mathrm{~nm}$ ) and LC-MS. After 15 minutes, the product $4 \mathbf{e}$ was isolated in $58 \%$ yield ( $*$ is a by-product from $\mathbf{2 c}$ ). The product was characterized by ESI-MS (mass obs. 2006.84 Da, calc. 2006.85 Da). The diarylation product (Se-Ph and S$\mathrm{Ph}$ ) of 4 e' was also observed (mass obs. 2082.96 Da, calc. 2082.88 Da). The results are shown in Fig. S24.
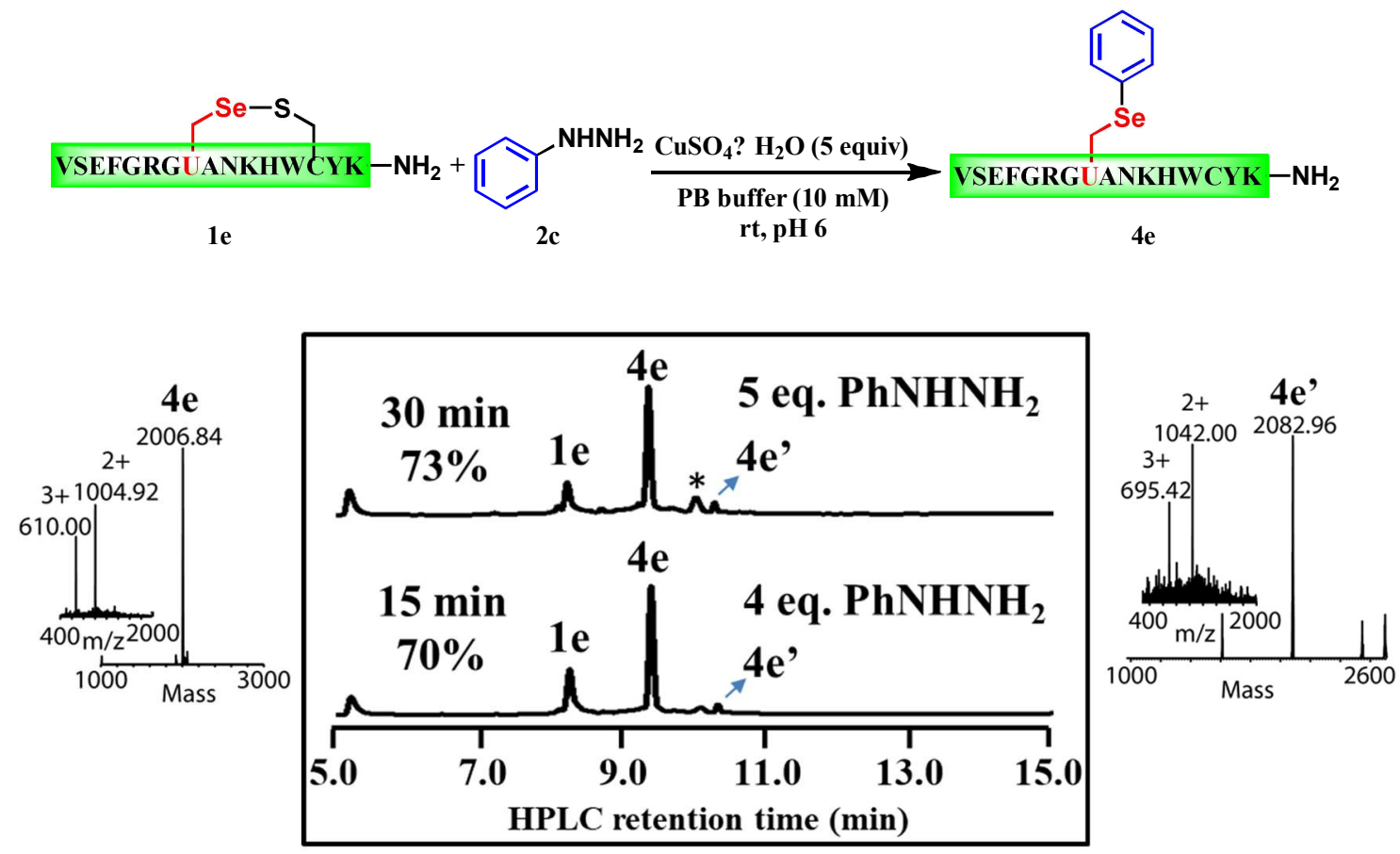

Figure S24. The modification of peptide 1e with phenylhydrazine 2c

2. The modification of peptide $\mathbf{1} \boldsymbol{f}$ with phenylhydrazine $\mathbf{2 c}$

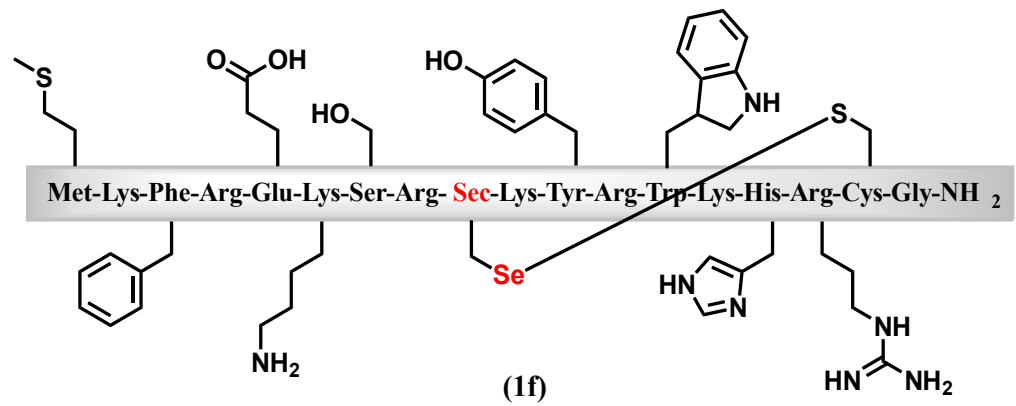

The peptide 1f $(1 \mu \mathrm{mol})$, also containing multiple reactive side-chains in addition to the Sec residue, and $\mathrm{CuSO}_{4}$ stock solution $(8 \mu \mathrm{mol}$, to prevent Met oxidation, the reaction was performed under anaerobic conditions, and hence excess copper was used) were dissolved in $700 \mu \mathrm{L}$ PB buffer (10 mM, pH 6, adjusted with $0.5 \mathrm{M} \mathrm{NaOH}) .2 \mathrm{c}(1.5 \mu \mathrm{mol})$ was dissolved in $300 \mu \mathrm{L}$ PB buffer (10 mM, pH 6). All solutions were degassed using a vacuum and argon bubbling for $5 \mathrm{~min}$. $\mathbf{2 c}$ solution was added dropwise to reaction mixtures of $\mathbf{1 f}$ and $\mathrm{CuSO}_{4}$ with argon bubbling. The reaction mixture was incubated under argon atmosphere at room temperature, and the progress was monitored by HPLC (using XSelect C18 column ( $3.5 \mu \mathrm{m}$, 
$130 \AA, 4.6 \times 150 \mathrm{~mm}$ ) with a gradient of $5 \%$ B over 5 min then $5-70 \%$ B over 20 min at 220 $\mathrm{nm})$ and LC-MS. After 30 minutes, the product $\mathbf{4 f}$ was isolated in $75 \%$ yield. The product was characterized by ESI-MS (mass obs. 2522.88 Da, calc. 2522.93 Da, Fig. S25).

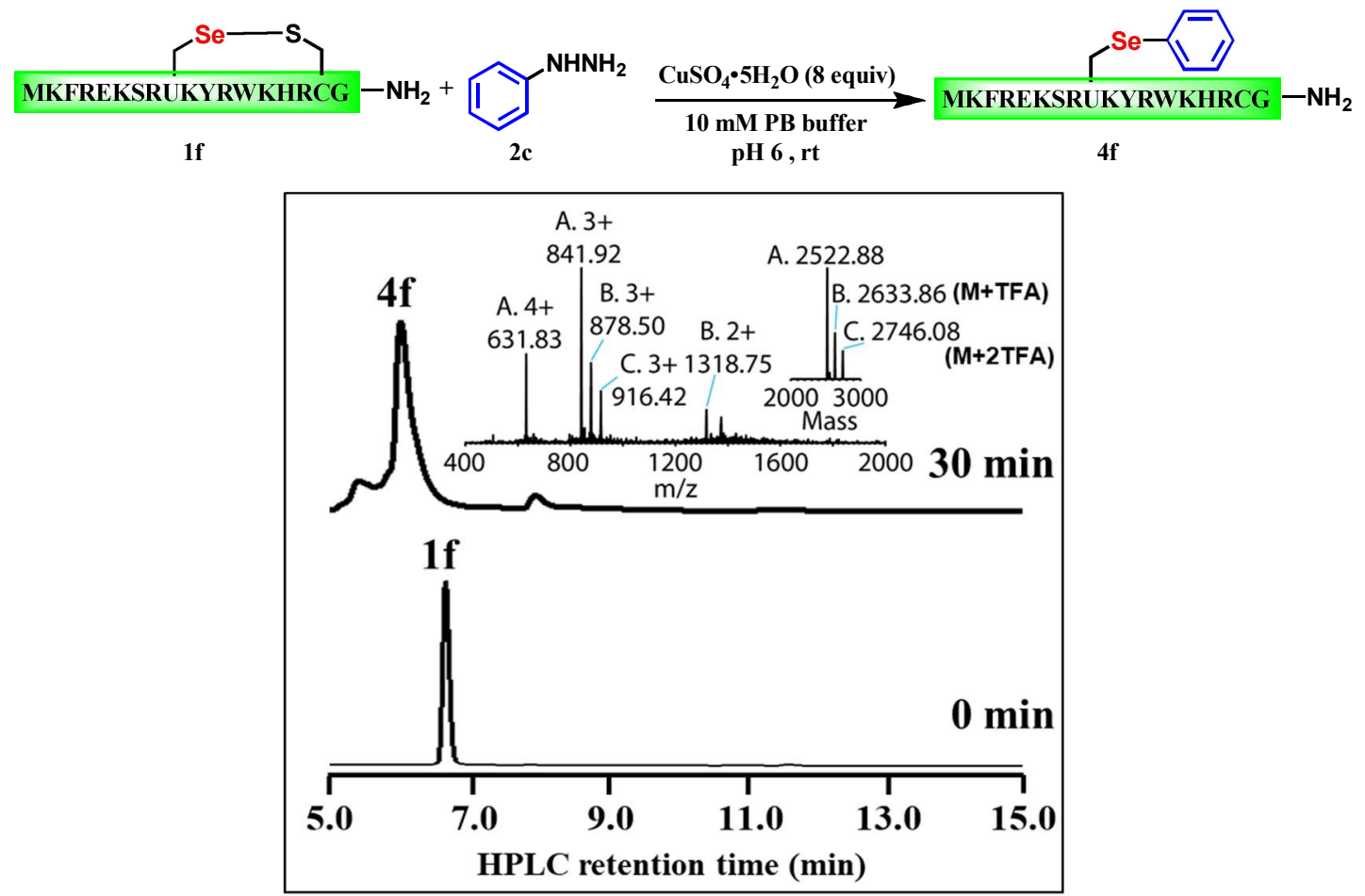

Figure S25. The modification of peptide $\mathbf{1 f}$ with phenylhydrazine $\mathbf{2 c}$

4. The modification of cyclic peptide $1 \mathrm{~g}$ with phenylhydrazine $2 \mathrm{c}$

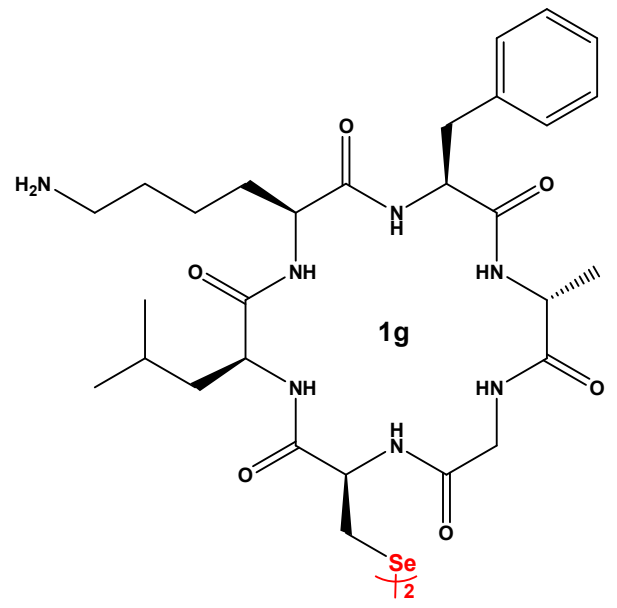

The peptide $1 \mathrm{~g}(1 \mu \mathrm{mol})$ and $\mathrm{CuSO}_{4}(2 \mu \mathrm{mol})$ dissolved in $700 \mu \mathrm{L}$ PB buffer $(10 \mathrm{mM}$, pH 6 , adjusted with $0.5 \mathrm{M} \mathrm{NaOH})$ was incubated at room temperature for $5 \mathrm{~min} .2 \mathbf{c}(2 \mu \mathrm{mol})$ dissolved in $300 \mu \mathrm{L}$ PB buffer ( $10 \mathrm{mM}, \mathrm{pH}$ 6) was added dropwise to the above reaction mixture. The reaction mixtures were incubated at $37^{\circ} \mathrm{C}$, and the reaction progress was monitored by HPLC (using XSelect C18 column $(3.5 \mu \mathrm{m}, 130 \AA, 4.6 \times 150 \mathrm{~mm})$ with a gradient of $5 \%$ B over $5 \mathrm{~min}$ then $5-70 \%$ B over $20 \mathrm{~min}$ at $220 \mathrm{~nm}$ ) and LC-MS. After 90 minutes, the product $4 \mathrm{~g}$ was isolated with $69 \%$. The product was characterized by ESI-MS $\left([\mathrm{M}+\mathrm{H}]^{+}\right.$obs. 744.33 , calc. 744.30 , Fig. $\mathrm{S} 26, *$ is a by-product from $\mathbf{2 c}$ ). 

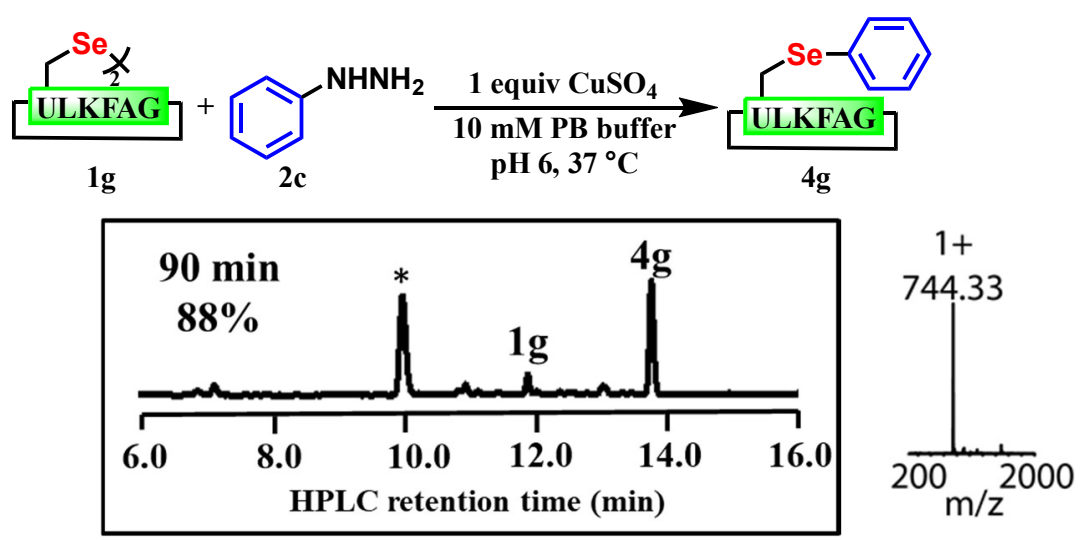

Figure S26. The modification of cyclic peptide $1 \mathbf{g}$ with phenylhydrazine $\mathbf{2 c}$

4. The modification of oxidized Sec-containing peptide $\mathbf{1 h}$ with phenylhydrazine $\mathbf{2 c}$

The peptide $1 \mathrm{~h}(1 \mu \mathrm{mol})$ and $\mathrm{CuSO}_{4}(1 \mu \mathrm{mol})$ dissolved in $700 \mu \mathrm{L}$ PB buffer $(10 \mathrm{mM}, \mathrm{pH}$, adjusted with $0.5 \mathrm{M} \mathrm{NaOH}$ ) was incubated at room temperature for $5 \mathrm{~min} .300 \mu \mathrm{L} \mathbf{2 c}$ solution ( $2 \mu \mathrm{mol}, \mathrm{pH} 6)$ was added dropwise to the above reaction mixture. The reaction mixtures were incubated at room temperature, and the reaction progress was monitored by HPLC (using XSelect C18 column $(3.5 \mu \mathrm{m}, 130 \AA, 4.6 \times 150 \mathrm{~mm})$ with a gradient of $5 \% \mathrm{~B}$ over 5 min then $5-70 \% \mathrm{~B}$ over $20 \mathrm{~min}$ at $220 \mathrm{~nm}$ ) and LC-MS. After5 minutes, the product $\mathbf{4 h}$ (the same as $\mathbf{3 c}$ ) was isolated in $69 \%$ yield. The product was characterized by ESI-MS $\left([\mathrm{M}+\mathrm{H}]^{+}\right.$obs. 678.17 , calc. 678.25 , Fig. S27, * is a by-product from $\mathbf{2 c}$ ).
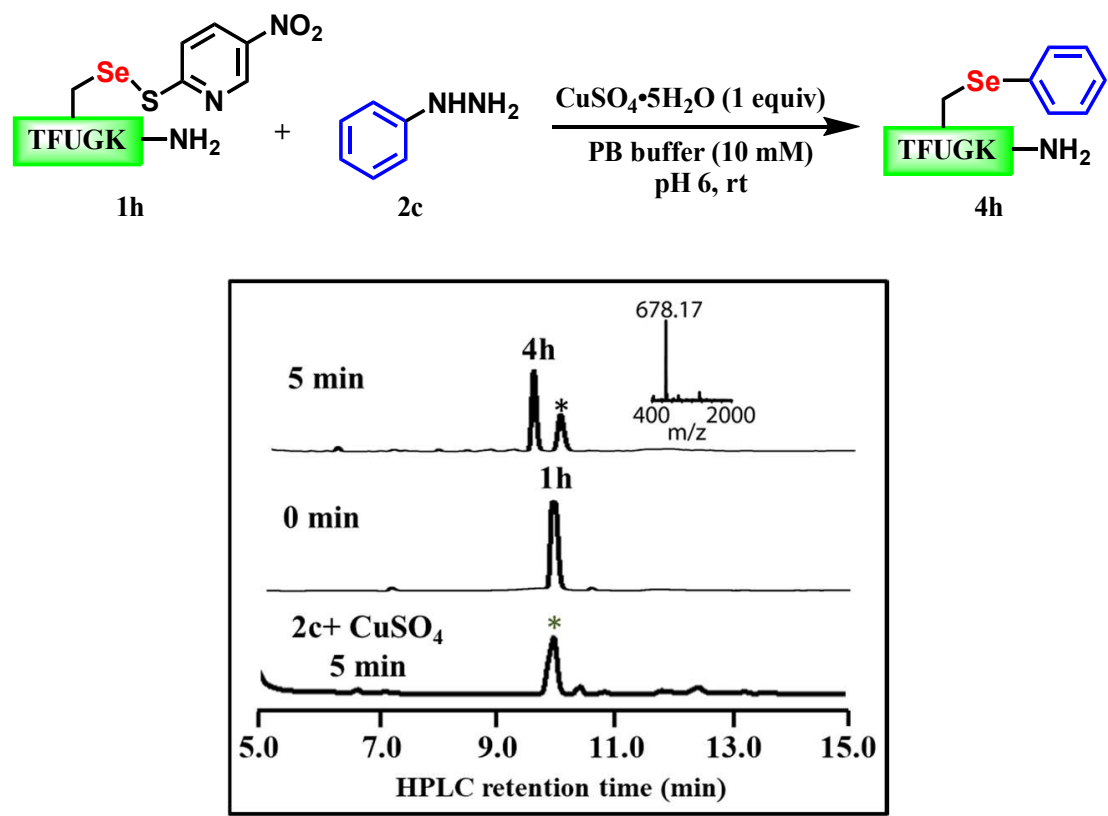

Figure S27. The modification of oxidized Sec-containing peptide $\mathbf{1 h}$ with phenylhydrazine 2c

\section{Trypsin digestion of modified peptide $4 \mathrm{e}$}

$1 \mathrm{mg}$ the product peptide $4 \mathbf{e}$ (vide supra) was dissolved in $980 \mu \mathrm{L}$ Tris $\bullet \mathrm{HCl}$ buffer $(100 \mathrm{mM}, \mathrm{pH}$ $8.5)$ as $4 \mathbf{e}$ stock solution, $0.6 \mathrm{mg}$ trypsin was dissolved in $600 \mu \mathrm{L}$ Tris buffer $(100 \mathrm{mM}, \mathrm{pH} 8.5)$ as trypsin stock solution. $2 \mu \mathrm{L}$ trypsin stock solution $(2 \mu \mathrm{g})$ was added to $98 \mu \mathrm{L} \mathbf{4 e}$ stock solution and 
incubated at $37^{\circ} \mathrm{C}$ for 18 hours. The reaction progress was monitored by HPLC (using XSelect $\mathrm{C} 18$ column $(3.5 \mu \mathrm{m}, 130 \AA, 4.6 \times 150 \mathrm{~mm})$ with a gradient of $5 \%$ B over 5 min then $5-70 \%$ B over 20 $\min$ at $220 \mathrm{~nm}$ ) and LC-MS. The HPLC analysis was carried out on a C18 analytical column using a gradient of 5\% B over $1 \mathrm{~min}$ then 5-70\% B over $20 \mathrm{~min}$. Solvent A: $0.1 \%(\mathrm{v} / \mathrm{v})$ TFA in water and Solvent B: 0.1\% (v/v) TFA in acetonitrile. (7a: $[\mathrm{M}+\mathrm{H}]^{+}$obs. 694.42 , calc. $694.35 \mathrm{Da}$; $7 \mathbf{b}:[\mathrm{M}+\mathrm{H}]^{+}$ obs. 616.17 , calc. $616.20 ; 7$ c: $[\mathrm{M}+\mathrm{H}]^{+}$obs. 1469.50 , calc. 1469.62 , Fig. S28).

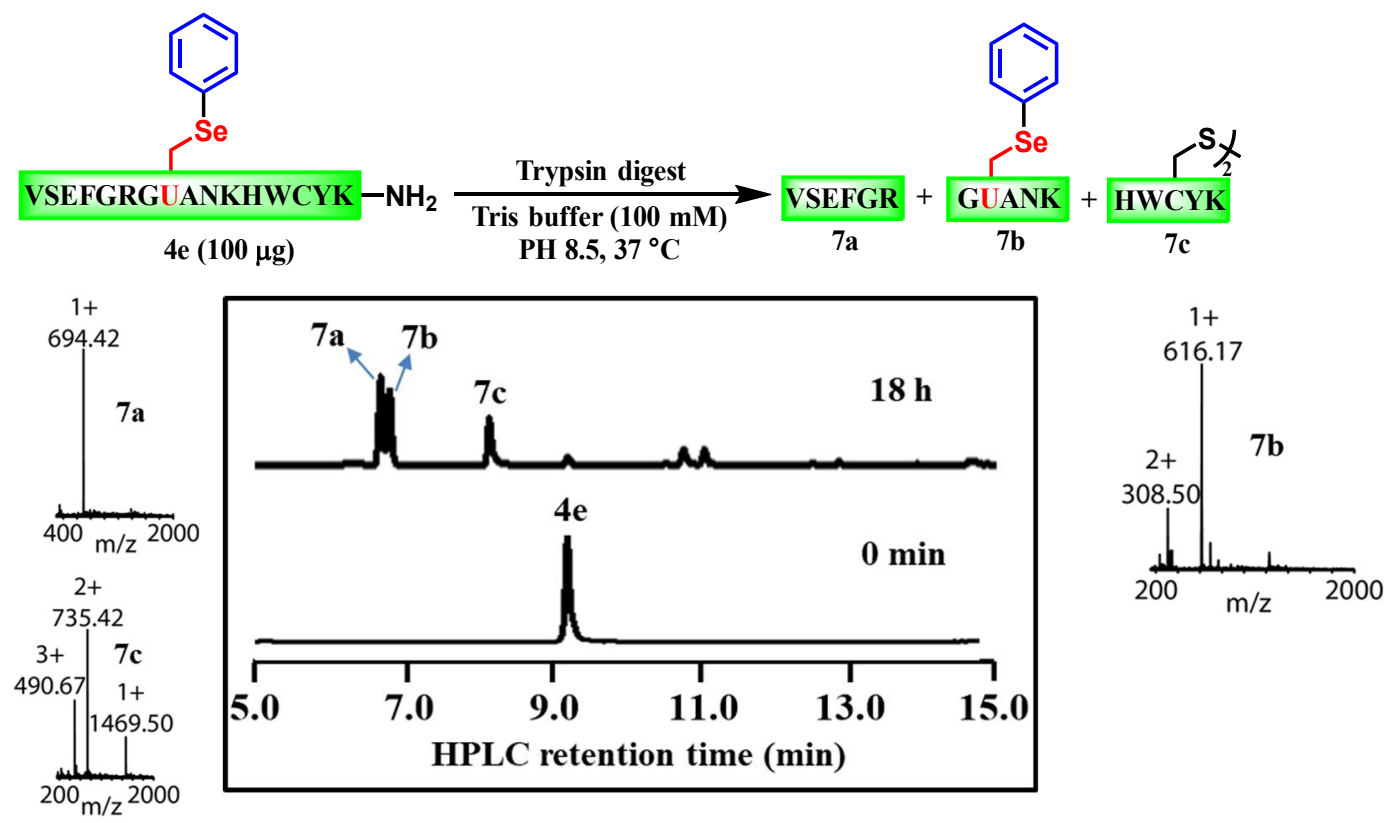

Figure S28. Trypsin digest of modified peptide $4 \mathbf{e}$

The synthesis of cyclic peptide $4 \mathrm{i}$ by the intramolecular reaction between phenylhydrazine and selenocysteine

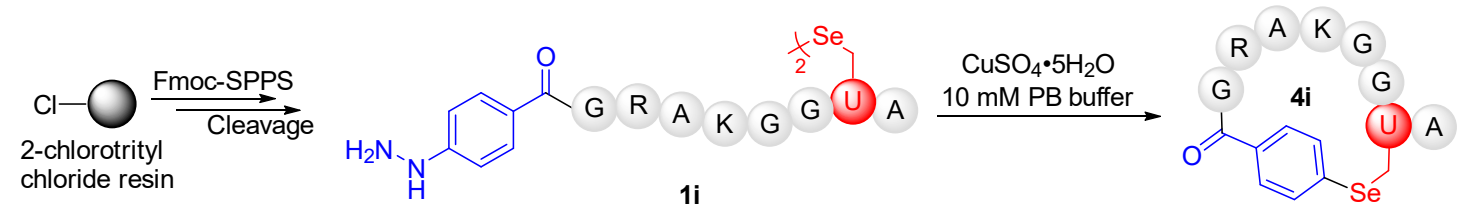

Scheme S3. The synthesis of cyclic peptide $4 \mathbf{i}$

\section{The synthesis of peptide $1 \boldsymbol{i}$}

The synthesis of peptide $1 \mathbf{i}$ was carried out manually on the 2-chlorotrityl chloride resin (loading $0.5 \mathrm{mmol} / \mathrm{g}, 0.25 \mathrm{mmol} \mathrm{scale}$ ). Fmoc-Sec(Mob)-OH was manually coupled at r.t for $2 \mathrm{~h}$ (activation: 2 equiv Fmoc-Sec(Mob)-OH, 2 equiv Oxyma, and 1.9 equiv DIC in 1:1 mixture of DCM and DMF at $0{ }^{\circ} \mathrm{C}$ for $5 \mathrm{~min}$ ). Fmoc-4-hydrazinobenzoic acid was coupled at r.t. for $2 \mathrm{~h}$ in $\mathrm{N}_{2}$ atmosphere. The peptide was cleaved using TFA: triisopropylsilane (TIPS): water (94:3:3) with 2 equiv DTNP cocktail for $2-4 \mathrm{~h}$ in $\mathrm{N}_{2}$ atmosphere. The peptide $1 \mathbf{i}$ was obtained in $20 \%$ yield after purification by RP-HPLC (with TCEP and sodium ascorbate). The HPLC analysis was carried out on a C18 analytical column using a gradient of 5\% B over $1 \mathrm{~min}$ then $5-70 \% \mathrm{~B}$ over $20 \mathrm{~min}$. The product was characterized by ESI-MS ([M + H $]^{+}$obs. 901.17, calc. 901.35, Fig. S29). 


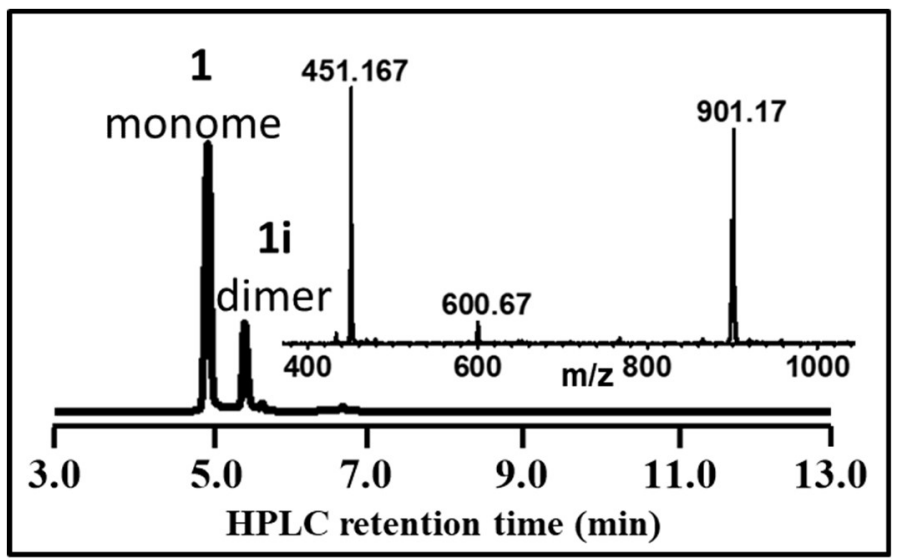

Figure S29. The synthesis of peptide 1i

\section{The cyclization of peptide $1 \mathbf{i}$ to generate cyclic peptide $4 \boldsymbol{i}$}

At first the reaction was carried out under standard reaction conditions. $\mathrm{CuSO}_{4}(1 \mu \mathrm{mol})$ dissolved in $500 \mu \mathrm{L}$ PB buffer $(10 \mathrm{mM}, \mathrm{pH} 6)$ was incubated at room temperature for $5 \mathrm{~min}$. 1i $(0.5 \mu \mathrm{mol})$ dissolved in $500 \mu \mathrm{L}$ PB buffer $(10 \mathrm{mM}, \mathrm{pH} 6)$ was added dropwise to $\mathrm{CuSO}_{4}$ solution. The reaction mixture was incubated at room temperature and the reaction progress was monitored by HPLC (using XSelect C18 column $(3.5 \mu \mathrm{m}, 130 \AA, 4.6 \times 150 \mathrm{~mm}$ ) with a gradient of $5 \%$ B over $5 \mathrm{~min}$ then $5-70 \%$ B over 20 min at $220 \mathrm{~nm}$ ) and LC-MS. After 10 minutes, the peptide $1 \mathbf{i}$ was consumed but only $45 \%$ yield of desired product $4 \mathbf{i}$ was observed with two main side products. Among them, one is formed by hydrogen transfer to the radical intermediate generated by the oxidation of peptide $\mathbf{1} \mathbf{i}$, marked as *; the other is self-coupling product of the radical intermediate to give a dimer, marked as \# (Fig. S30). All the products were characterized by ESI-MS (4i: $[\mathrm{M}+\mathrm{H}]^{+}$obs. 869.25, calc. 869.32; *: [M+ H $]^{+}$obs. 871.17, calc. 871.33; \#: mass obs. $1738.50 \mathrm{Da}$, calc. 1738.63 Da).

Thus, the reaction conditions for the cyclization of peptide $\mathbf{1 i}$ were further optimized. When the cyclization reactions were conducted at $100 \mu \mathrm{M}$ and $50 \mu \mathrm{M}$ concentrations of $1 \mathbf{i}$, the target product were obtained in $61 \%$ and $65 \%$ yields, respectively. Lastly, the best result was with peptide $1 \mathbf{i}$ (50 $\mu \mathrm{M})$ with 10 equiv $\mathrm{CuSO}_{4}$ in $\mathrm{PB}$ buffer $(10 \mathrm{mM}, \mathrm{pH}$ 5) at room temperature. After 10 minutes, cyclic product $4 \mathbf{i}$ was observed in 74\% HPLC conversion and 58\% isolated yield by semipreparative column. The results are shown in Fig. S30. 


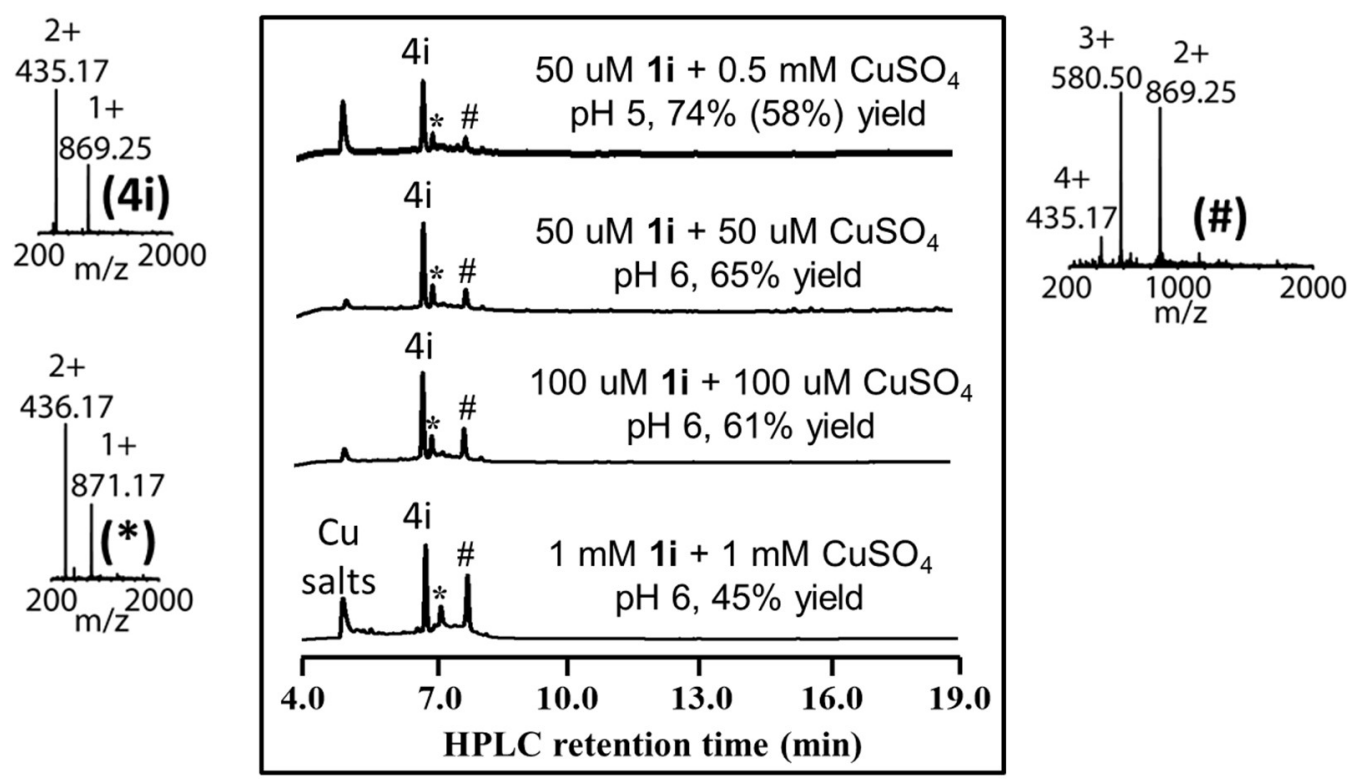

Figure S30. The cyclization of peptide 1i to generate cyclic peptide $4 \mathbf{i}$

The chemical synthesis of Ubiquitin(G47U), 5a, and Ubiquitin(G47A), $5 b$.

The sequence of wild type of ubiquitin:

\begin{tabular}{|crrr|}
\hline 10 & 20 & 30 & 40 \\
MQIFVKTLTG KTITLEVEPS & DTIENVKAKI & QDKEGIPPDQ \\
50 & 60 & 70 & \\
& & & \\
QRLIFAGKQL EDGRTLSDYN & IQKESTLHLV & LRLRGG & \\
\hline
\end{tabular}

Since ubiquitin does not contain a Cys residue, we decided to use Sec-NCL reaction to prepare the protein. Gly47 (red in the sequence), which is solvent exposed was substituted with Sec. Ubiquitin(G47U), 5a, was prepared from two peptide segments with one ligation reaction, and the ligated product was deselenized for the preparation of Ubiquitin(G47A), 5b. The ligation sites is underlined.

The synthesis of ubiquitin(1-46)-MPAA thioester (5a 1$)$

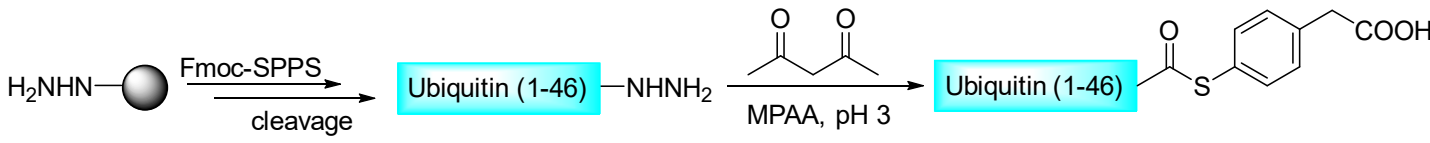

Scheme S4. The synthesis of ubiquitin(1-46)-MPAA thioester (5a $\left.\mathbf{a}_{1}\right)$

The procedure for the synthesis of C-terminal peptide hydrazides: 2-chlorotrityl chloride resin (0.5 $\mathrm{mmol} / \mathrm{g}, 0.25 \mathrm{mmol}$ scale) was swelled in DMF for $1 \mathrm{~h}$. The resin was double treated with freshly prepared 10\% hydrazine in DMF for 30 min and drained. The resin was washed well with DMF and then treated with $10 \% \mathrm{MeOH}$ in DMF for $30 \mathrm{~min}$. This hydrazine functionalized resin can be utilized in standard peptide couplings.

The synthesis of ubiquitin(1-46)- $\mathrm{NHNH}_{2}$ was carried out on hydrazide functionalized 2-chlorotrityl chloride $\operatorname{resin}^{6}(0.5 \mathrm{mmol} / \mathrm{g}, 0.25 \mathrm{mmol}$ scale $)$ on automated peptide synthesizer. After peptide chain 
assembly, the resin was washed well with DMF/DCM, and dried under vacuum. The peptide was cleaved according to the general procedure and lyophilized.

The thioesterification of ubiquitin(1-46)- $\mathrm{NHNH}_{2}$ : The crude peptide was dissolved in $20 \mathrm{~mL} \mathrm{~PB}$ buffer $(200 \mathrm{mM}, 6 \mathrm{M} \mathrm{Gn} \cdot \mathrm{HCl}, \mathrm{pH} 3)$ and treated with MPAA $(200 \mathrm{mM})$ and 25 equiv acetylacetone (acac) for $3 \mathrm{~h}$ at $25^{\circ} \mathrm{C}^{7}$ The reaction was monitored using analytical HPLC (C4 column) with a gradient of 5\% B over $5 \mathrm{~min}$ then 5-70\% B over $20 \mathrm{~min}$ and ESI-MS and purified by prep. RPHPLC (C4 column) to give the corresponding ubiquitin(1-46)-MPAA peptide thioester (5a $\left.\mathbf{a}_{1}\right)$ in $~ 30 \%$ yield. The product was characterized by ESI-MS (mass obs. 5334.7 Da, calc. 5334.8 Da, Fig. S31).

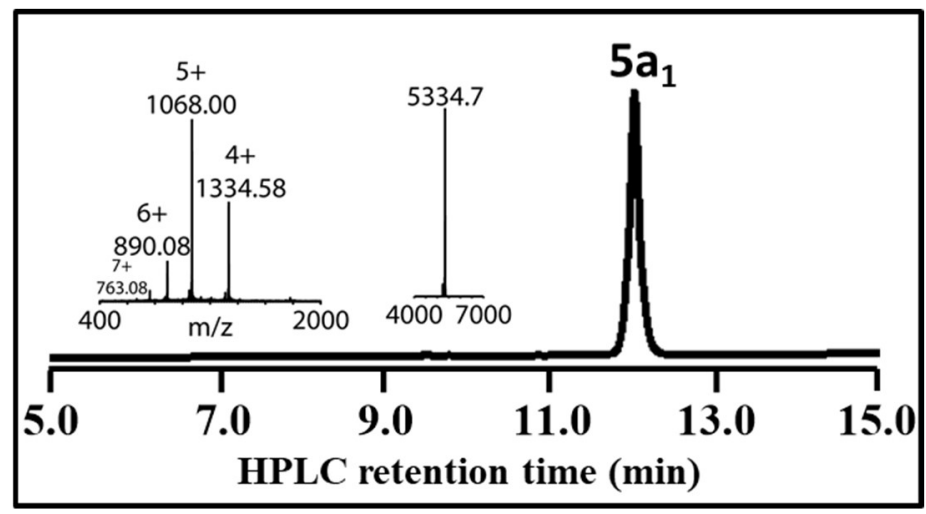

Figure S31. The HPLC trace and Mass spectra of $\mathbf{5} \mathbf{a}_{1}$

\section{The synthesis of ubiquitin(47-76)(G47U) dimer $\left(5 \mathrm{a}_{2}\right)$}

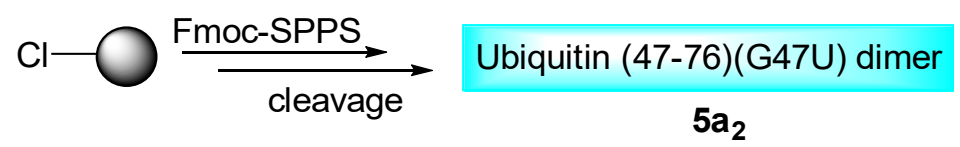

Scheme S5. The synthesis of ubiquitin(47-76)(G47U) dimer (5a 2 )

The synthesis of ubiquitin(47-76)(G47U) dimer (5a $\left.\mathbf{a}_{2}\right)$ was carried out on 2-chlorotrityl chloride resin $(0.5 \mathrm{mmol} / \mathrm{g}, 0.25 \mathrm{mmol}$ scale) on automated peptide synthesizer. The first amino acid Gly 76 was double coupled and subsequent steps were completed with standard Fmoc-SPPS. Fmoc-Sec(Mob)$\mathrm{OH}$ replacing Gly47 was manually coupled at r.t for $2 \mathrm{~h}$ (activation: 2 equiv Fmoc-Sec(Mob)-OH, 2 equiv Oxyma, and 1.9 equiv DIC in $1: 1$ mixture of $\mathrm{CH}_{2} \mathrm{Cl}_{2}$ and DMF at $0{ }^{\circ} \mathrm{C}$ for $5 \mathrm{~min}$ ). After peptide chain assembly, the peptide was cleaved according to the general procedure and lyophilized. The corresponding peptide ubiquitin(47-76)(G47U) dimer (52 $\left.\mathbf{a}_{2}\right)$ was obtained in $\sim 30 \%$ yield by prep. RP-HPLC. The HPLC analysis was carried out on a $\mathrm{C} 4$ analytical column using a gradient of $5 \% \mathrm{~B}$ over $1 \mathrm{~min}$ then $5-70 \% \mathrm{~B}$ over $20 \mathrm{~min}$. The product was characterized by ESI-MS (with TCEP/sodium ascorbate, mass of the dimer obs. $6978.7 \mathrm{Da}$, average calc. 6977.5 Da, Fig. S32). 


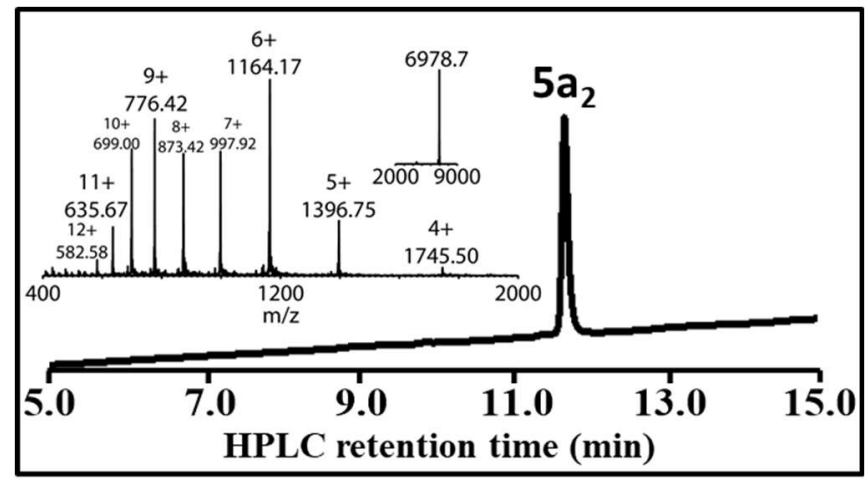

Figure S32. The HPLC trace and Mass spectra of $\mathbf{5} \mathbf{a}_{2}$

The native chemical ligation of ubiquitin(1-46)-MPAA thioester $\left(5 a_{1}\right)$ and ubiquitin(4776)(G47U) dimer (5a $)$

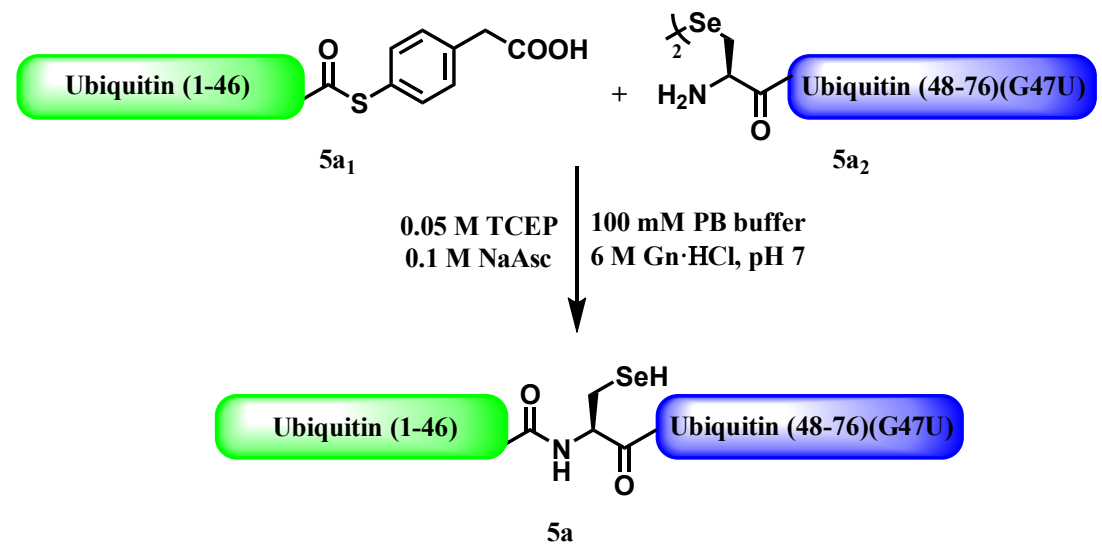

Scheme S6. The synthesis of ubiquitin(G47U, 5a)

Ubiquitin(47-76)(G47U) dimer (5. $\mathbf{a}_{2}, 7.7 \mathrm{mg}, 0.55 \mu \mathrm{mol}, 1.1 \mathrm{mM}$ with respect to monomer ) was dissolved in $1 \mathrm{~mL}$ PB buffer (100 mM, $6 \mathrm{M} \mathrm{Gn} \cdot \mathrm{HCl}, 50 \mathrm{mM}$ TCEP, $100 \mathrm{mM}$ ascorbate, $\mathrm{pH}$ 7) and the reaction mixtures were added to ubiquitin(1-46)-MPAA thioester (5a $\left.\mathbf{a}_{1}, 5.3 \mathrm{mg}, 1.0 \mu \mathrm{mol}, 1 \mathrm{mM}\right)$. The reaction mixtures were incubated at $37^{\circ} \mathrm{C}$ for $1.5 \mathrm{~h}$. The reaction progress was monitored by HPLC with a gradient of $5 \%$ B over $1 \mathrm{~min}$ then $5-70 \%$ B over $20 \mathrm{~min}$. The product $5 \mathbf{a}$ was isolated in $30 \%$ yield and characterized by ESI-MS (with TCEP/sodium ascorbate, mass obs. 8656.6 Da, calc. average 8656.6 Da, Fig. S33).
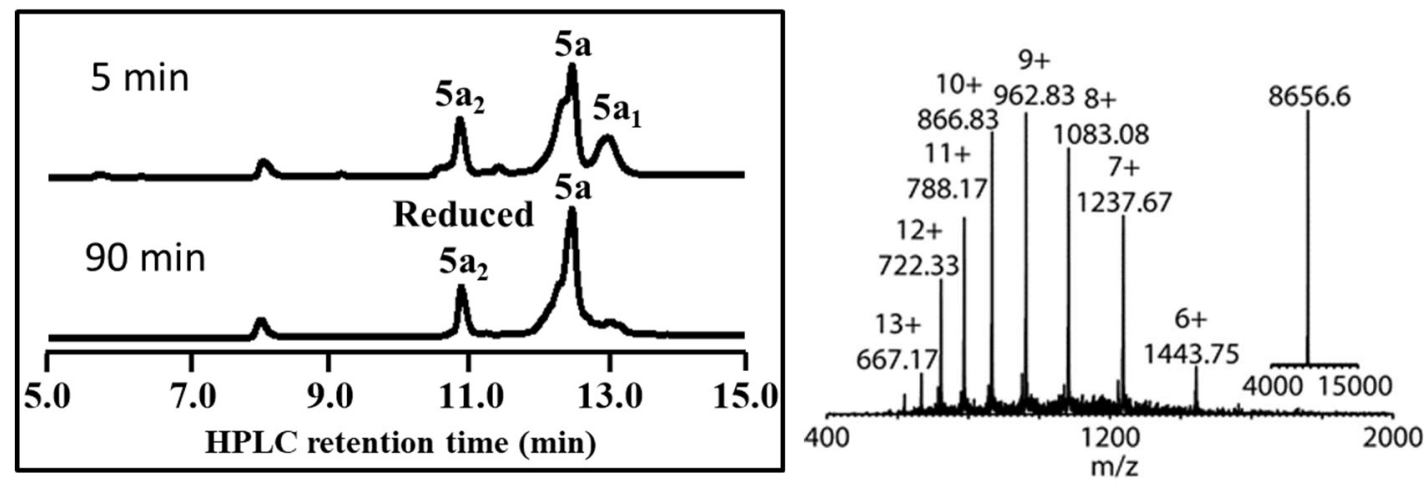

Figure S33. The synthesis of ubiquitin(G47U), 5a. 
The deselenization of ubiquitin(G47U), 5a, to prepare ubiquitin(G47A), $5 \mathrm{~b}$.

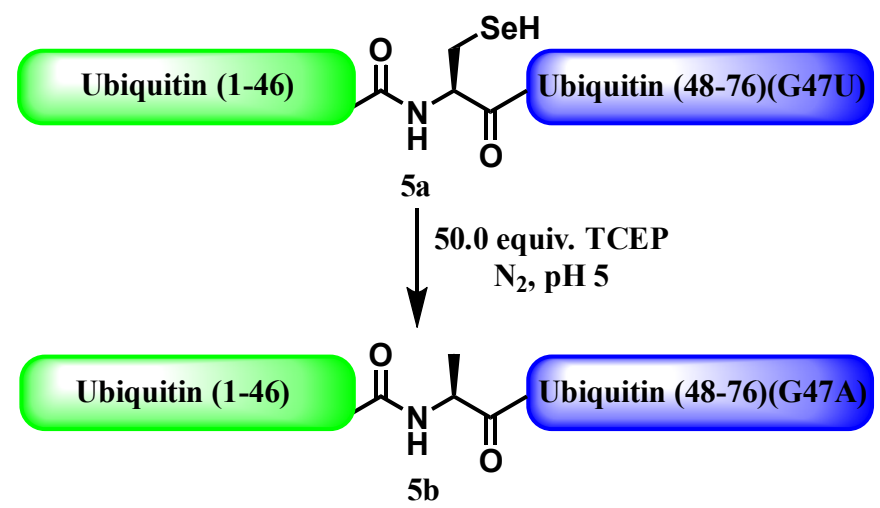

Scheme S7. The synthesis of ubiquitin(G47A), $\mathbf{5 b}$.

Ubiquitin(G47U), 5a, was deselenized by 50 equiv. TCEP in PB buffer (100 mM, pH 5) under $\mathrm{N}_{2}$ atmosphere. The reaction was completed within $3 \mathrm{~h}$ and the product ubiquitin(G47A), $\mathbf{5 b}$, was isolated in $45 \%$ yield and characterized by ESI-MS (mass obs. $8576.4 \mathrm{Da}$, calc. $8576.6 \mathrm{Da}$, Fig. S34).

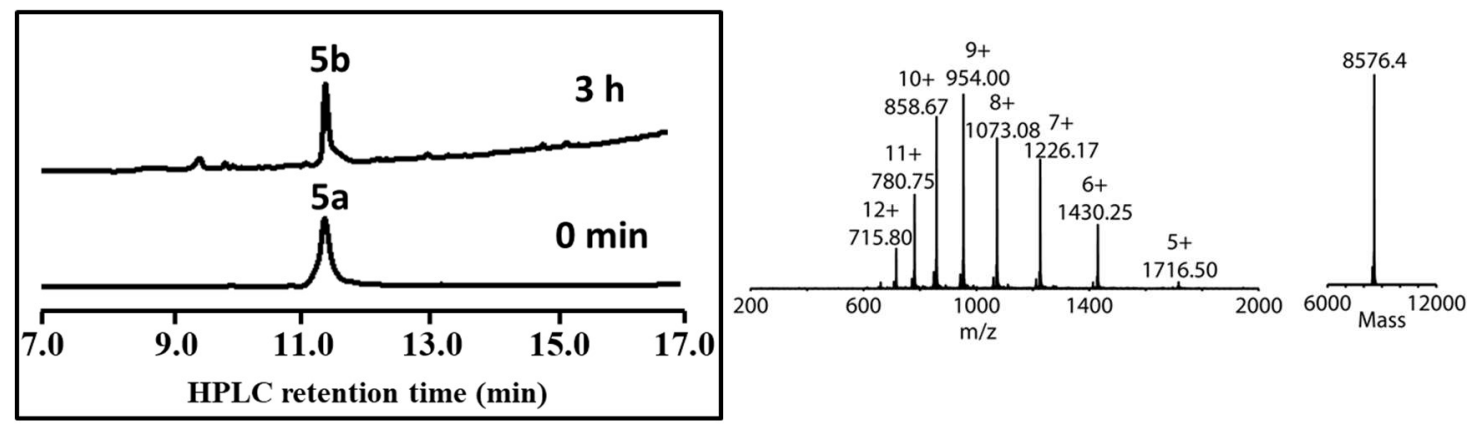

Figure S34. The synthesis of ubiquitin(G47A), 5b, (analytic HPLC using XSelect C18 column (3.5 $\mu \mathrm{m}, 130 \AA, 4.6 \times 150 \mathrm{~mm}$ ) with a gradient of $5 \% \mathrm{~B}$ over $5 \mathrm{~min}$ then $5-70 \% \mathrm{~B}$ over $20 \mathrm{~min}$ at 220 $\mathrm{nm})$

\section{The reaction of ubiquitin(G47U) and ubiquitin(G47A) with 21 in the presence of $\mathrm{Cu}$ ions}

The preparation of protein and $\mathrm{CuSO}_{4}$ stock solution. Two stock solutions of the two proteins we made by dissolving $0.8 \mathrm{mg}$ ubiquitin(G47U) (5a as a dimer, $0.046 \mu \mathrm{mol}$ ) and ubiquitin(G47A), (5b, $0.093 \mu \mathrm{mol})$ in $10 \mu \mathrm{L} \mathrm{PB}$ buffer $(100 \mathrm{mM}, 6 \mathrm{M} \mathrm{Gn} \cdot \mathrm{HCl}, \mathrm{pH} 7)$, respectively, and diluted dropwise (1 drop per sec) with $82 \mu \mathrm{L} \mathrm{PB}$ buffer $(10 \mathrm{mM}$, pH 6, final Con. $1 \mathrm{mM}$ ), and left for $2 \mathrm{~h} .9 .2 \mathrm{mg}$ $\mathrm{CuSO}_{4} \cdot 5 \mathrm{H}_{2} \mathrm{O}(10 \mu \mathrm{mol}, 184 \mathrm{mM})$ was dissolved in $0.2 \mathrm{~mL}$ TDW as stock solution. $3.9 \mathrm{mg}$ biotincontaining phenylhydrazine (2l, $8.8 \mu \mathrm{mol}, 92 \mathrm{mM})$ was dissolved in $0.1 \mathrm{~mL}$ PB buffer $(10 \mathrm{mM}, \mathrm{pH}$ 6) as stock solution.

Copper mediated biotinylation of ubiquitin(G47U) with $2 l$. $10 \mu \mathrm{L}$ ubiquitin(G47U) (5a dimer, 0.046 $\mu \mathrm{mol})$ stock solution and $2 \mu \mathrm{L} \mathrm{CuSO}_{4}$ stock solution $(0.37 \mu \mathrm{mol})$ were diluted dropwise in $38 \mu \mathrm{L}$ PB buffer $(10 \mathrm{mM}, \mathrm{pH}$ 6) and incubated at room temperature for 5 minutes. $2 \mu \mathrm{L} 2 \mathbf{l}$ stock solution $(0.184 \mu \mathrm{mol})$ was diluted in $48 \mu \mathrm{L}$ PB buffer $(10 \mathrm{mM}, \mathrm{pH}$ 6) and then added dropwise to reaction mixtures. The reaction mixtures were incubated at room temperature for $30 \mathrm{~min}$. The reaction progress was monitored by HPLC (C18 column) with a gradient of 5\% B over 1 min then 5-70\% B over $20 \mathrm{~min}$. The experiments were repeated five times, which were combined for purification. The 
product 6a was isolated in $60 \%$ yield and characterized by ESI-MS analysis (mass obs. 9046.4 Da, calc. isotopic average $9046.4 \mathrm{Da}$ ). The results are shown in Fig. S35.

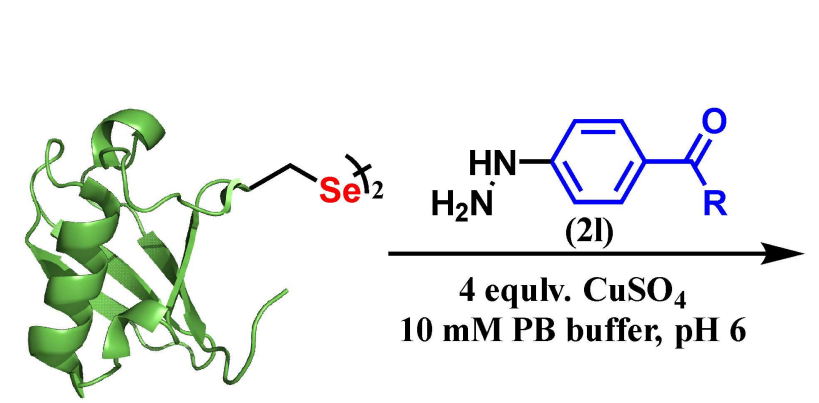

(5a dimer)

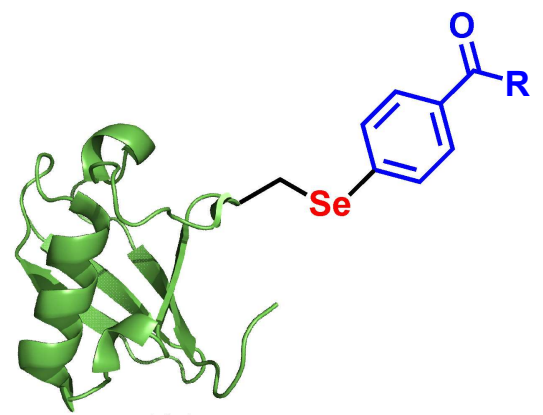

(6a)

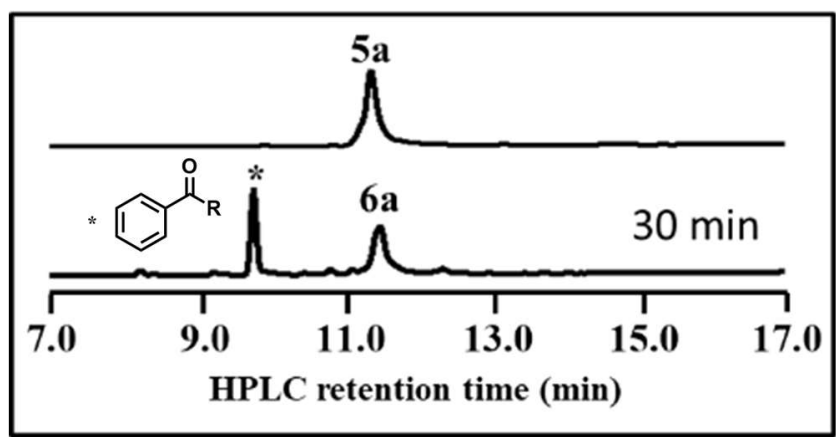<smiles>[R]#CCNCCNC(=O)CCCC[C@H]1SC[C@@H]2NC(=O)N[C@@H]21</smiles>

Figure S35. Copper-mediated biotinylation of ubiquitin(G47U) with $\mathbf{2 1}$.

The reaction of ubiquitin $(G 47 A)$ with $2 \boldsymbol{l}$. The reaction was carried out under the same reaction conditions as with ubiquitin(G47U), yet no modification of protein ubiquitin(G47A), 5b, was observed after $30 \mathrm{~min}$ and $\mathbf{2} \mathbf{I}$ was completely consumed to afford three side products. The reaction progress was monitored by HPLC (C18 column) with a gradient of 5\% B over 1 min then 5-70\% B over $20 \mathrm{~min}$. The products were characterized by ESI-MS (side product $\&$ : $[\mathrm{M}+\mathrm{H}]^{+}$obs. 407.17 , calc. 407.17; side product *: [M+H] $]^{+}$obs. 391.25 , calc. $[\mathrm{M}+\mathrm{H}]$ 391.18; side product \#: $[\mathrm{M}+\mathrm{H}]^{+}$obs. 779.42, calc. 779.34). The results were showed in Fig. S36.
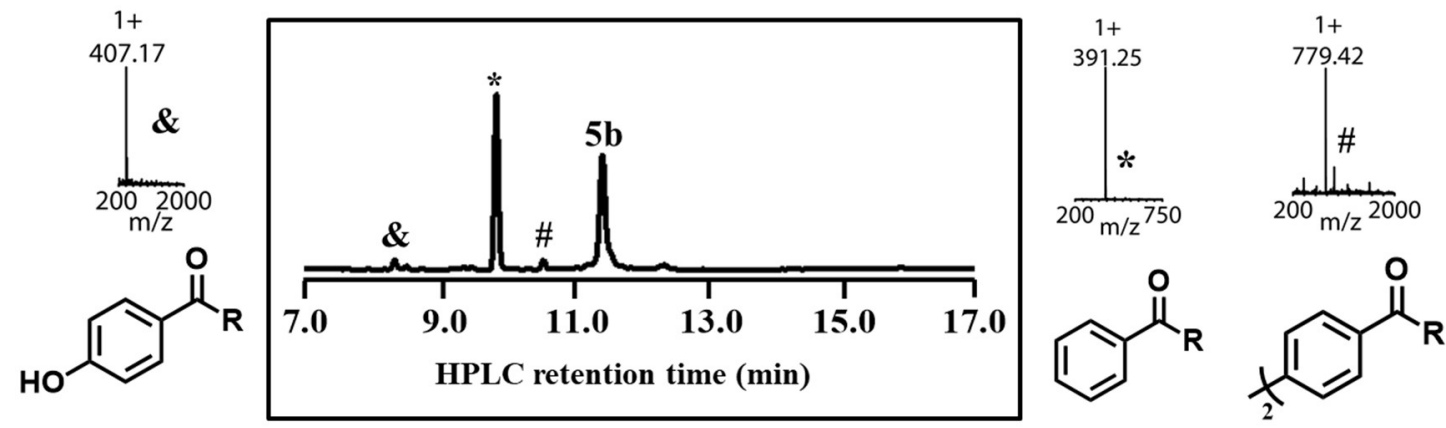

Figure S36. Reaction of ubiquitin(G47A), 5b, with $\mathbf{2 l}$ in the presence of copper ion. 
Chemical synthesis of the seleno-variant of stromal cell-derived factor 1 (SDF1(S25U))

The sequence of SDF1:

$\begin{array}{ccccr}10 & 20 & 30 & 40 & 50 \\ \text { MNAKVVVVLV LVLTALCLSD GKPVSLSYRC PCRFFESHVA RANVKHLKIL } \\ 60 & 70 & 80 & 90 \\ \text { NTPNCALQIV ARLKNNNRQV CIDPKLKWIQ EYLEKALNKR FKM }\end{array}$

Peptide (1-21) is a signal peptide, so we decide to prepare the mature SDF1 with the sequence form 22 to 93 . Ser25 (red in the sequence), which is solvent exposed was substituted with Sec, the site of modification. SDF1(S25U), 7a, was prepared from two peptide segments with one ligation reaction, and after purification, an oxidative folding provided the folded protein. The ligation sites is underlined.

The synthesis of SDF1(22-54)(S25U)-MPAA thioester (7a 1 )

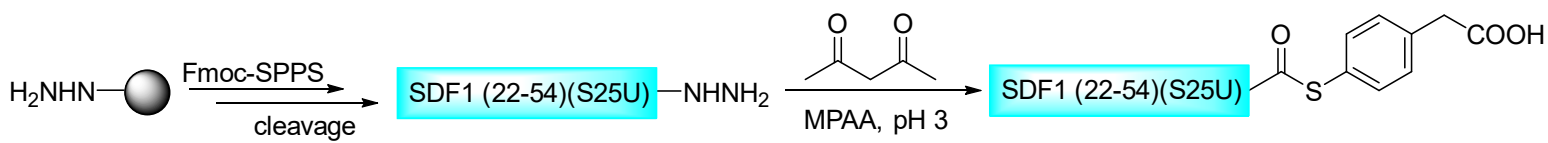

Scheme S8. The synthesis of SDF1(22-54)(S25U)-MPAA thioester (7a $\left.\mathbf{a}_{1}\right)$

SDF1(22-54)(S25U)-MPAA thioester (7a $\left.\mathbf{a}_{1}\right)$ was prepared in a similar fashion to the synthesis procedure of ubiquitin (1-46)-MPAA (5a $\mathbf{a}_{1}$ ), and purified by HPLC to give SDF1(22-54)(S25U)MPAA thioester $\left(\mathbf{7 a}_{\mathbf{1}}\right)$ was obtained in $\sim 20 \%$ yield. The product was characterized by analytical HPLC (C4 column) with a gradient of 5\% B over 5 min then 5-70\% B over 20 min and ESI-MS (mass obs. 4039.35 Da, calc. 4039.68 Da, Fig. S37).

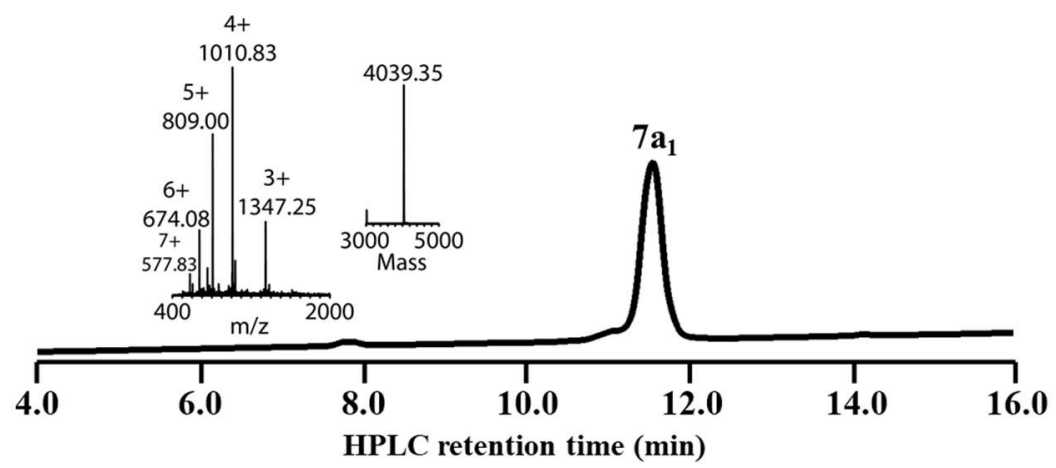

Figure S37. The HPLC trace and Mass spectra of 7a

The synthesis of SDF1(55-93) (7a $)$

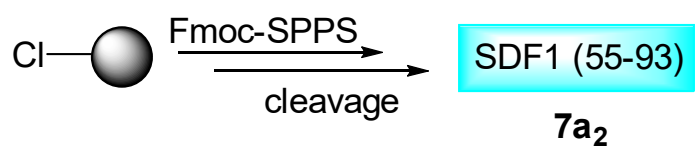

Scheme S9. The synthesis of SDF1(55-93) (7a 2 ) 
SDF1(55-93) (7. $\left.\mathbf{a}_{2}\right)$ was synthesized by standard Fmoc-SPPS according to the general procedures as with ubiquitin(45-76)(G47U). After purification, SDF1(55-93) (7a 2 ) was obtained in $\sim 15 \%$ yield. The product was characterized by analytical HPLC (C4 column) with a gradient of 5\% B over 5 min then 5-70\% B over 20 min and ESI-MS (mass obs. 4717.20 Da, calc. 4717.69 Da, Fig. S38).

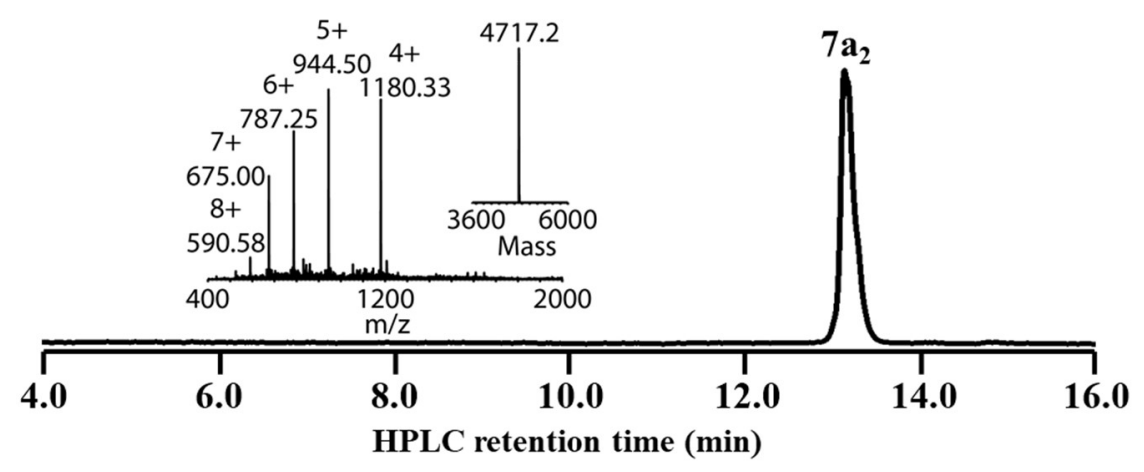

Figure S38. The HPLC trace and Mass spectra of $7 \mathbf{a}_{2}$

The native chemical ligation of SDF1(22-54)(S25U)-MPAA thioester (7a 1 ) and SDF1(55-93) $\left(7 \mathbf{a}_{2}\right)$

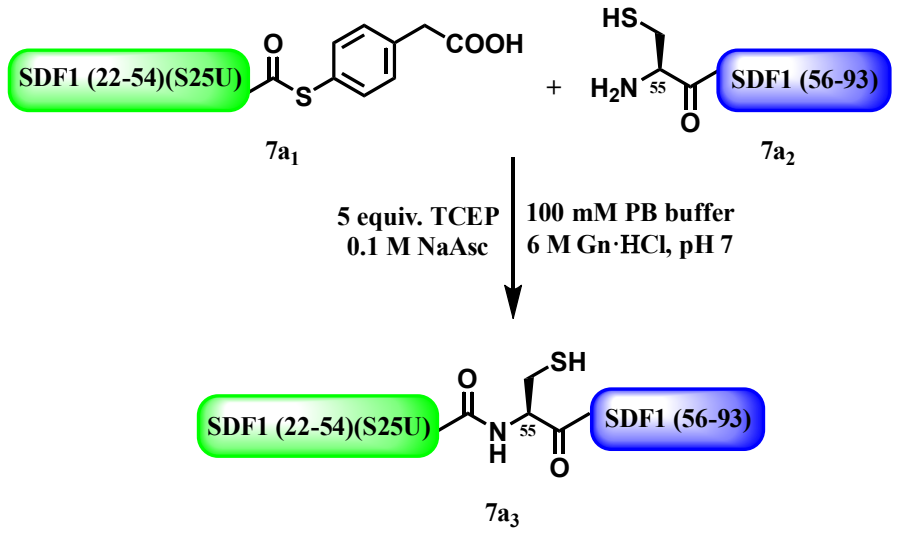

Scheme S10. The synthesis of SDF1(S25U)(7a 3$)$

SDF1(55-93) (7. $\left.\mathbf{a}_{2}, 5.2 \mathrm{mg}, 1.1 \mu \mathrm{mol}, 1.1 \mathrm{mM}\right)$ was dissolved in $1 \mathrm{~mL}$ PB buffer (100 mM, $6 \mathrm{M}$ $\mathrm{Gn} \cdot \mathrm{HCl}, 5 \mathrm{mM}$ TCEP, $100 \mathrm{mM}$ ascorbate, $\mathrm{pH}$ 7) and the reaction mixtures were added to SDF1(2254)(S25U)-MPAA thioester $\left(7 \mathbf{a}_{1}, 4.0 \mathrm{mg}, 1.0 \mu \mathrm{mol}, 1 \mathrm{mM}\right)$. The reaction mixtures were incubated at $37{ }^{\circ} \mathrm{C}$ for $4 \mathrm{~h}$. The reaction progress was monitored by HPLC with a gradient of $5 \% \mathrm{~B}$ over $1 \mathrm{~min}$ then $5-70 \%$ B over $20 \mathrm{~min}$. The product $7 \mathbf{a}_{3}$ was isolated in $55 \%$ yield and characterized by ESIMS (with TCEP/sodium ascorbate, mass obs. $8589.00 \mathrm{Da}$, calc. average 8589.16 Da, Fig. S39). 


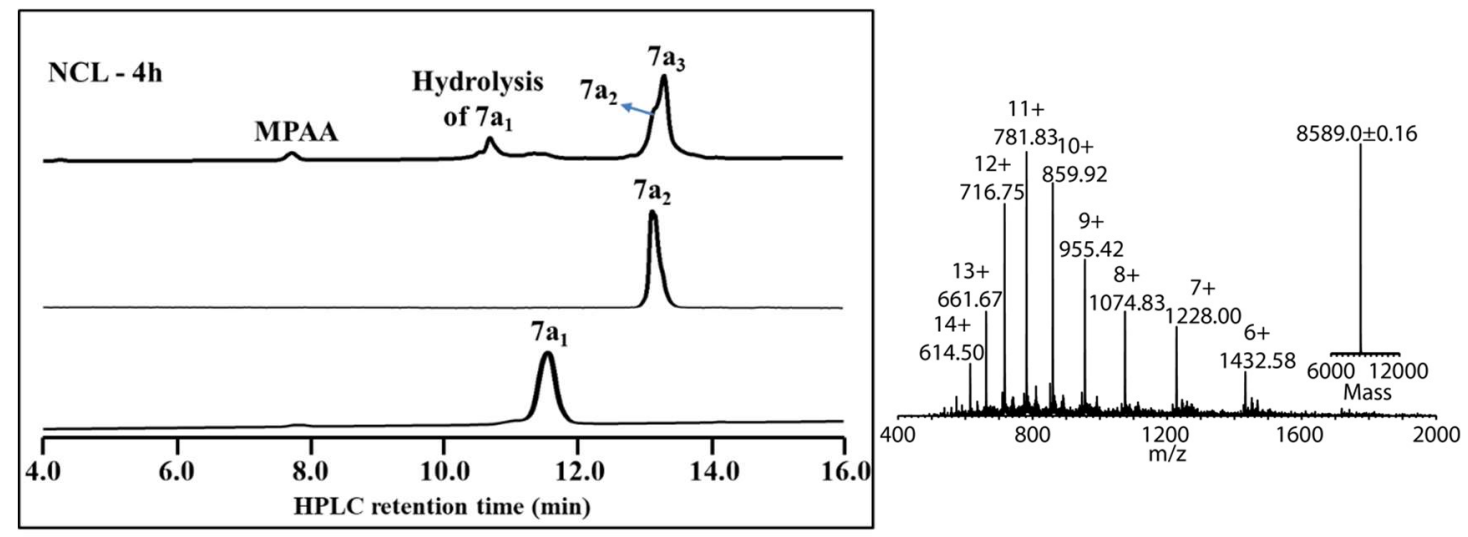

Figure S39. The synthesis of SDF1(S25U), 7a 3 , (analytic HPLC using XSelect C4 column (3.5 $\mu \mathrm{m}$, $130 \AA, 4.6 \times 150 \mathrm{~mm}$ ) with a gradient of $5 \%$ B over 5 min then $5-70 \%$ B over 20 min at $220 \mathrm{~nm}$ )

\section{Oxidative Folding of SDF1(S25U)}

The reduced SDF1(S25U), 7a 3 , $(5 \mathrm{mg}, 0.58 \mu \mathrm{mol}, 58 \mu \mathrm{M})$ was dissolved in $100 \mu \mathrm{L} 6 \mathrm{M} \mathrm{GdnHCl}$ solution, which was then diluted in $10 \mathrm{~mL}$ Tris buffer $(100 \mathrm{mM}, 5 \mathrm{mM}$ EDTA, $5 \mathrm{mM}$ reduced glutathione, $2.5 \mathrm{mM}$ oxidized glutathione, $\mathrm{pH} 8) .^{8}$ The reaction mixture was incubated for $29 \mathrm{~h}$ at room temperature in the anaerobic chamber. The reaction progress was monitored by HPLC with a gradient of 5\% B over $1 \mathrm{~min}$ then 5-70\% B over $20 \mathrm{~min}$. The folded glutathionylated-SDF1(S25U), SDF1(S25U)-SG 7a, (with Sec25 bound to GSH molecule by a selenylsulfide bond) was isolated in $10 \%$ yield and characterized by ESI-MS (mass obs. $8889.8 \mathrm{Da}$, calc. average $8890.4 \mathrm{Da}$, Fig. S40), the mass indicated the formation of two disulfide bonds, and the selenylsulfide bond between Sec25 and GSH.
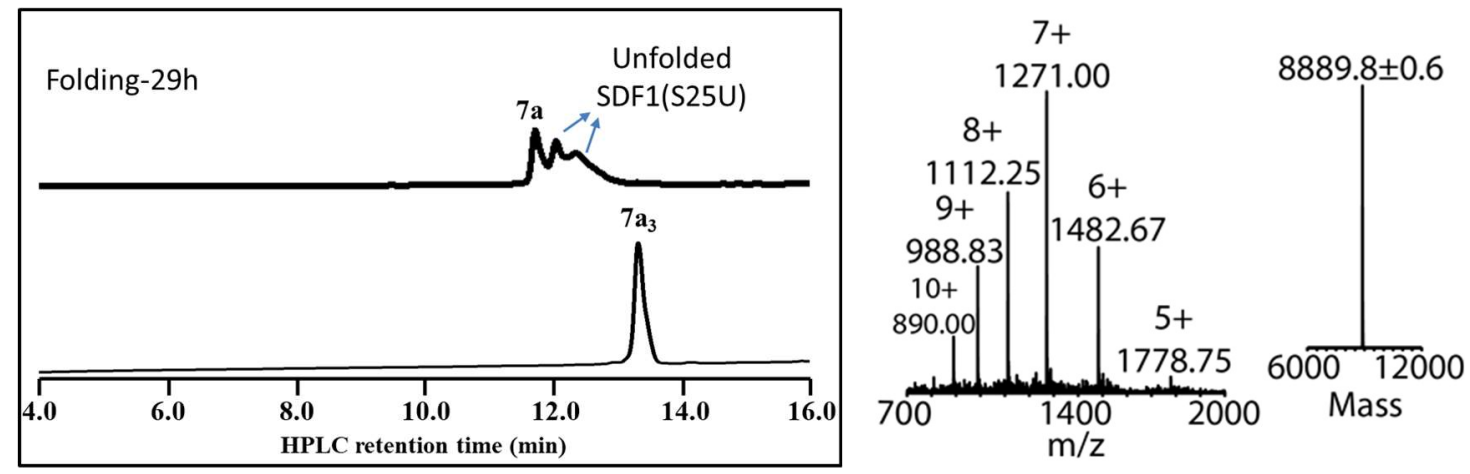

Figure S40. The folding of SDF1(S25U), 7a 3 , (analytic HPLC using XSelect C4 column $(3.5 \mu \mathrm{m}$, $130 \AA, 4.6 \times 150 \mathrm{~mm}$ ) with a gradient of $5 \%$ B over 5 min then $5-70 \%$ B over 20 min at $220 \mathrm{~nm}$ )

\section{The modification of SDF1(S25U)-SG adduct $7 \mathrm{a}$ with $2 \mathrm{I}$ in the presence of $\mathrm{Cu}$ (II)}

The preparation of protein and $\mathrm{CuSO}_{4}$ stock solution. The stock solutions of the protein we made by dissolving $4.5 \mathrm{mg}$ SDF1(S25U)-SG adduct (7a, $0.5 \mu \mathrm{mol})$ in $26 \mu \mathrm{L} \mathrm{PB}$ buffer (10 mM, pH 8.5, final Con. $19 \mathrm{mM})$, and left for $2 \mathrm{~h}$. Separately, $2.5 \mathrm{mg} \mathrm{CuSO} \cdot 5 \mathrm{H}_{2} \mathrm{O}(10 \mu \mathrm{mol}, 200 \mathrm{mM})$ was dissolved in $50 \mu \mathrm{L}$ TDW as stock solution. $2.5 \mathrm{mg}$ biotin-containing phenylhydrazine (21, $5.95 \mu \mathrm{mol}$, $297 \mathrm{mM}$ ) was dissolved in $20 \mu \mathrm{L}$ PB buffer (10 mM, pH 7.5) as stock solution.

Copper mediated biotinylation of SDF1(S25U)-SG adduct with $2 l .5 \mu \mathrm{L} \mathrm{CuSO}_{4}$ stock solution (1.0 $\mu \mathrm{mol})$ and $13 \mu \mathrm{L}$ SDF1(S25U)-SG adduct (7a, $0.25 \mu \mathrm{mol})$ stock solution was dissolved in $62 \mu 1 \mathrm{~PB}$ 
buffer ( $10 \mathrm{mM}, \mathrm{pH}$, adjusted by $10 \mathrm{mM} \mathrm{NaOH})$, which was incubated at room temperature for 5 minutes. $10 \mu \mathrm{L} \mathrm{2l}$ stock solution $(3.0 \mu \mathrm{mol})$ was diluted in $160 \mu \mathrm{L} \mathrm{PB}$ buffer $(10 \mathrm{mM}, \mathrm{pH}$ 6) and then added dropwise to reaction mixtures. The reaction mixtures were incubated at room temperature for $30 \mathrm{~min}$. The reaction progress was monitored by HPLC ( $\mathrm{C} 4$ column) with a gradient of $5 \% \mathrm{~B}$ over $1 \mathrm{~min}$ then $5-70 \% \mathrm{~B}$ over $20 \mathrm{~min}$. The product $8 \mathrm{a}$ was isolated in $48 \%$ yield and characterized by ESI-MS analysis (mass obs. 8972.4 Da, calc. isotopic average 8972.6 Da). The results are shown in Fig. S41.
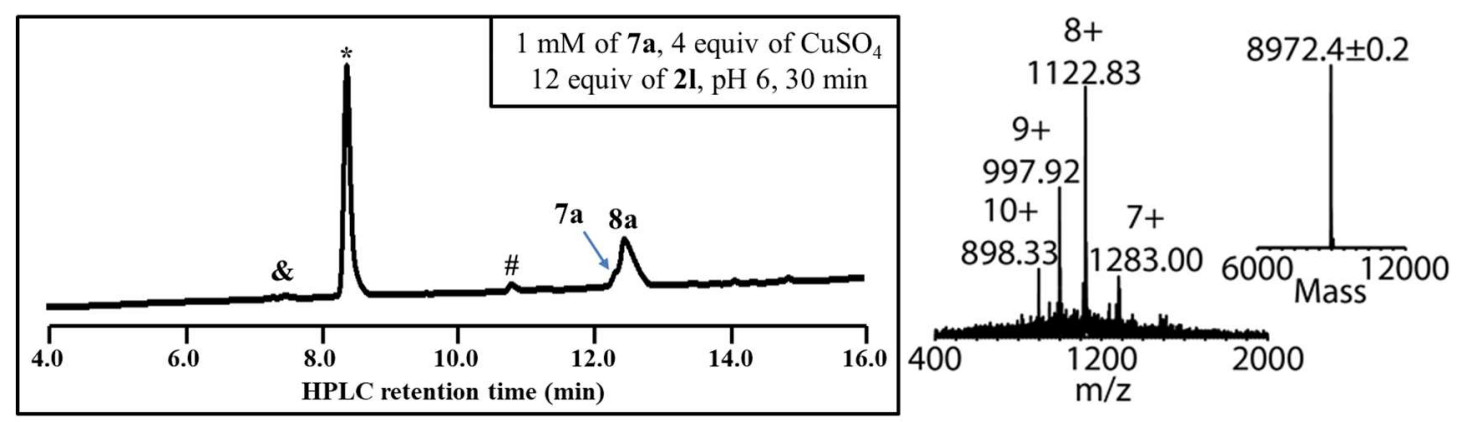

Figure S41. Copper-mediated biotinylation of SDF1(S25U)-SG adduct with $2 \mathbf{I}$

\section{The study of chemoselective modification of SDF1(S25U) by deselenization reaction}

To confirm that the biotinylation of SDF1(S25U) occur on Sec25, we decided to test the deselenization of unmodified SDF1(S25U)-SG adduct (7a $\mathbf{a}_{\mathbf{3}}$ ) and biotinylated SDF1(S25U) (8a). 0.9 $\mathrm{mg}$ of $8 \mathbf{a}(0.1 \mu \mathrm{mol}, 1 \mathrm{mM})$ and $0.9 \mathrm{mg}$ of $7 \mathbf{a}_{3}(0.1 \mu \mathrm{mol}, 1 \mathrm{mM})$ were dissolved in $100 \mu \mathrm{L}$ PB buffer (100 mM, 0.05 M TCEP, $\mathrm{pH}$ 5), respectively. The two reaction mixtures were incubated at room temperature in anaerobic chamber. The reaction progress was monitored by HPLC (C4 column) with a gradient of $5 \%$ B over $1 \mathrm{~min}$ then $5-70 \%$ B over $20 \mathrm{~min}$. After $3 \mathrm{~h}$, we found the deselenated product SDF1(S25A)(9a) from deselenization reaction of $\mathbf{7} \mathbf{a}_{3}$ (Fig. S42a), while only disulfidereduced bioyinylated SDF1(S25U) (10a) was observed, with no deselenization reaction occurred (Fig. S42b). These results indicate that the biotinylation of $\mathbf{7} \mathbf{a}_{3}$ is chemoselective on the Sec residue, which render it inert to the deselenization reaction. The product 9a and 10a were characterized by ESI-MS analysis (for 9a, mass obs. 8509.0 Da, calc. isotopic average 8508.6 Da, for 10a, mass obs. 8978.0 Da, calc. isotopic average 8577.6 Da). The results are shown in Fig. S42. For HRMS see Fig. S78.
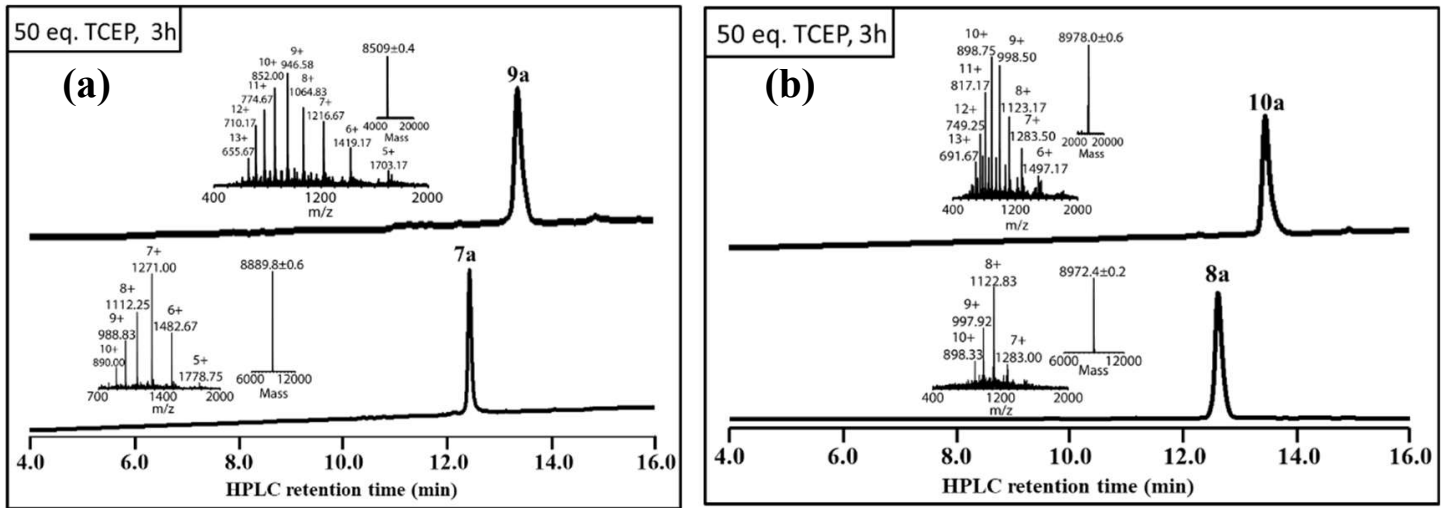

Figure S42. The deselenization reaction of $7 \mathbf{a}_{3}$ and $\mathbf{8 a}$ 
${ }^{1}$ H-NMR \& ${ }^{13}$ C-NMR Spectrum

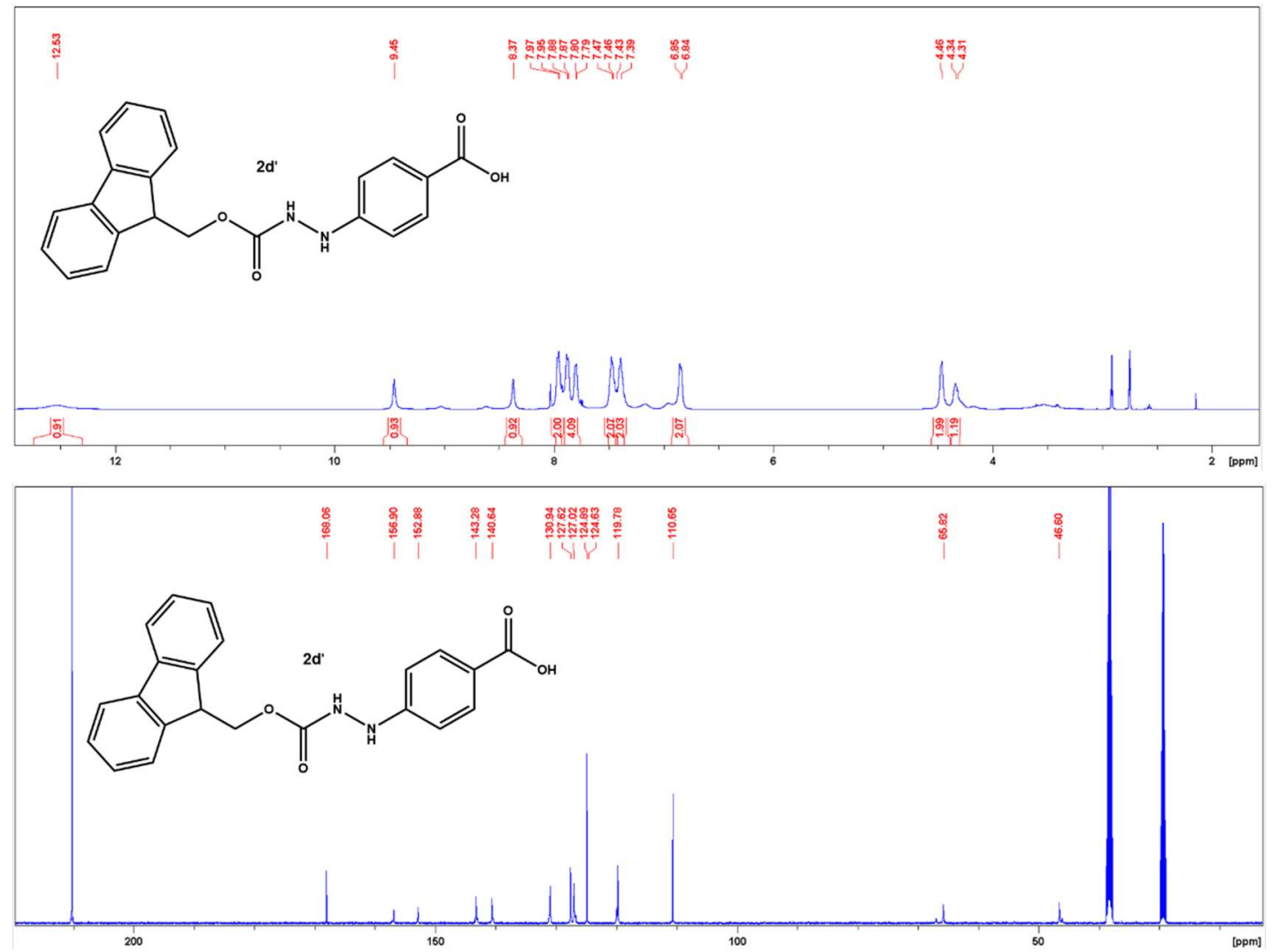

Figure S43. The ${ }^{1} \mathrm{H}-\mathrm{NMR}$ and ${ }^{13} \mathrm{C}-\mathrm{NMR}$ Spectrum of Fmoc-4-hydrazinobenzoic acid, 2d' 


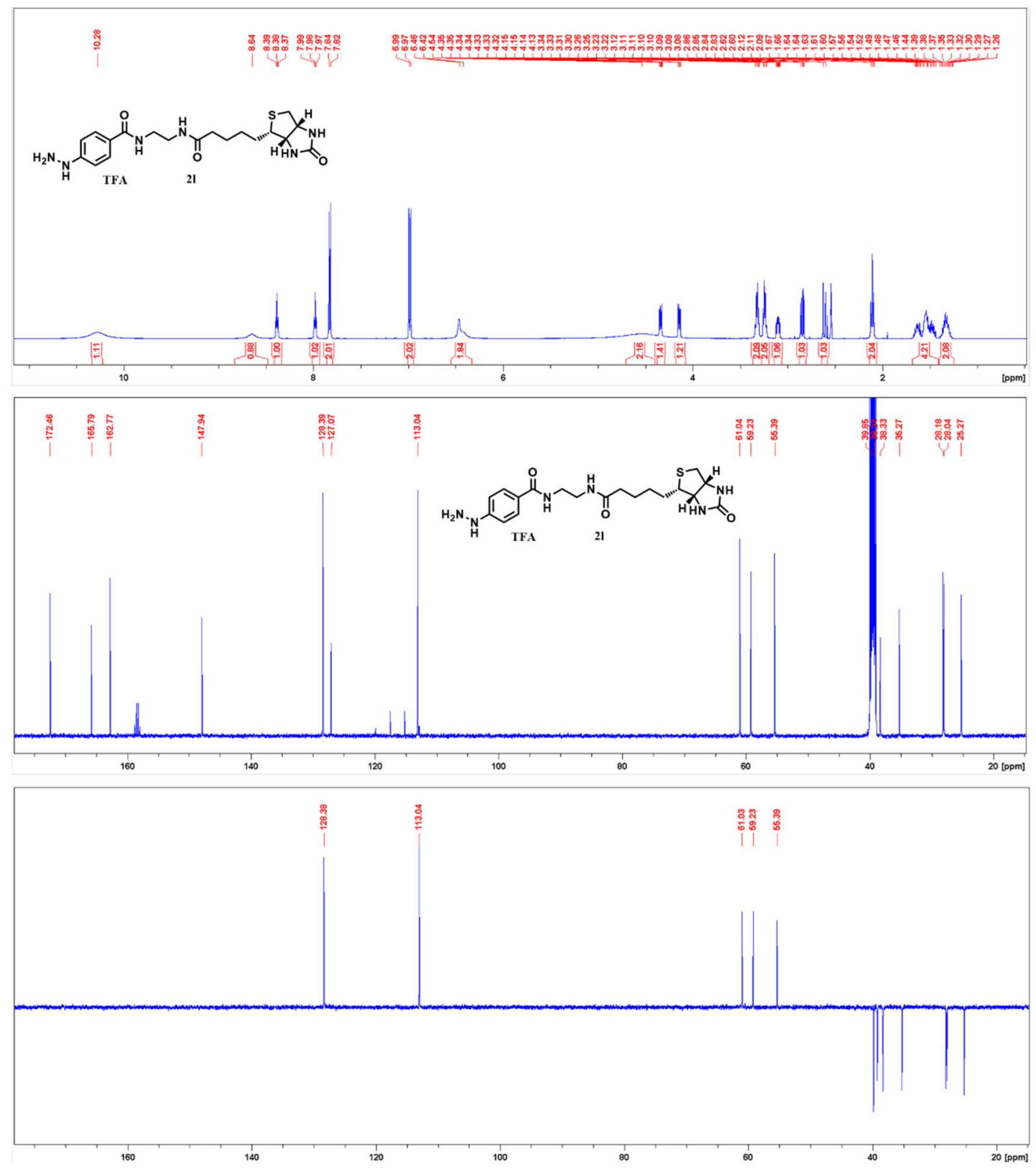

Figure S44. The ${ }^{1} \mathrm{H}-\mathrm{NMR},{ }^{13} \mathrm{C}-\mathrm{NMR}$ and DEPT135 Spectrum of $2 \mathrm{I}$ 


\section{Supplementary Figures}

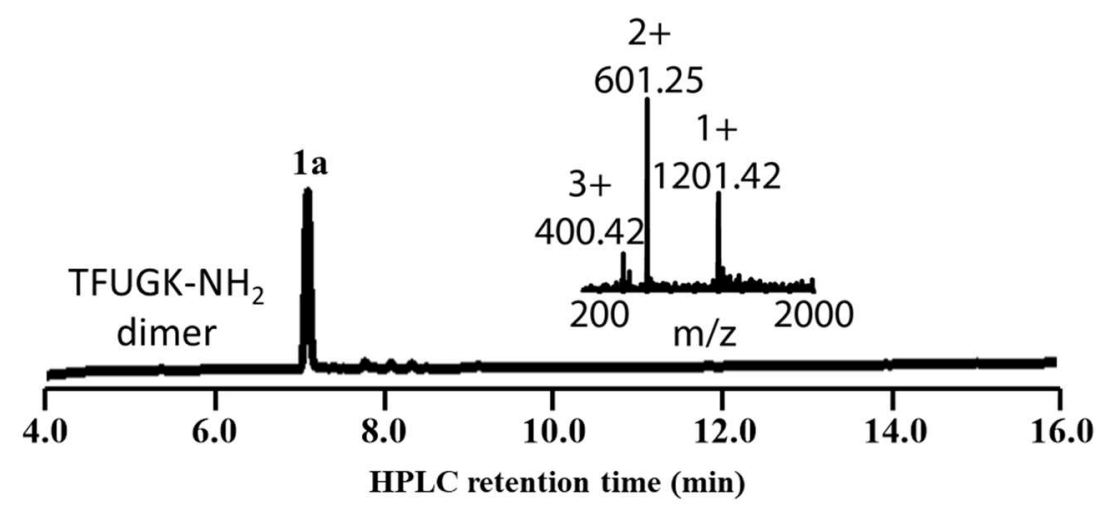

Figure S45. Analytical HPLC (using XSelect C18 column $(3.5 \mu \mathrm{m}, 130 \AA, 4.6 \times 150 \mathrm{~mm})$ at 220 $\mathrm{nm})$ and ESI-MS of 1a $\left([\mathrm{M}+\mathrm{H}]^{+}\right.$obs. 1201.42, calc. 1201.42).

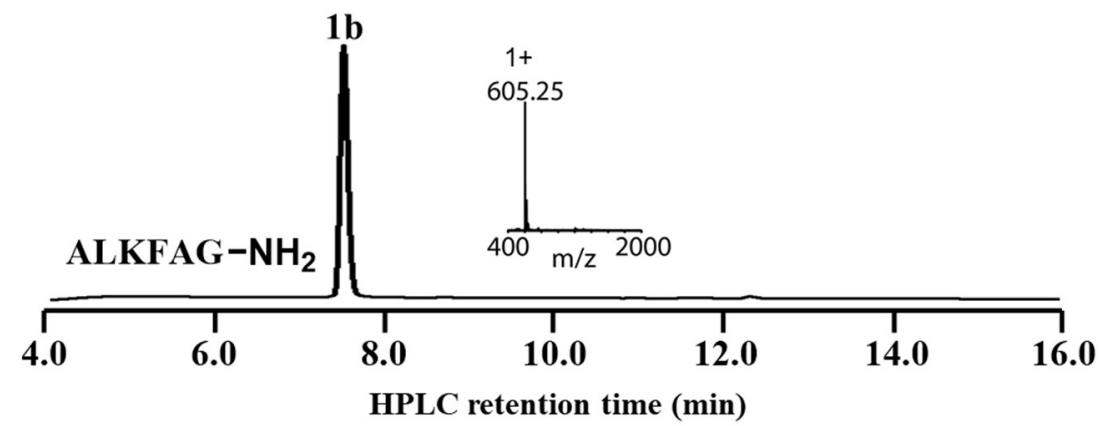

Figure S46. Analytical HPLC (using XSelect C18 column $(3.5 \mu \mathrm{m}, 130 \AA, 4.6 \times 150 \mathrm{~mm})$ at 220 $\mathrm{nm})$ and ESI-MS of $\mathbf{1 b}\left([\mathrm{M}+\mathrm{H}]^{+}\right.$obs. 605.25, calc. 605.38).

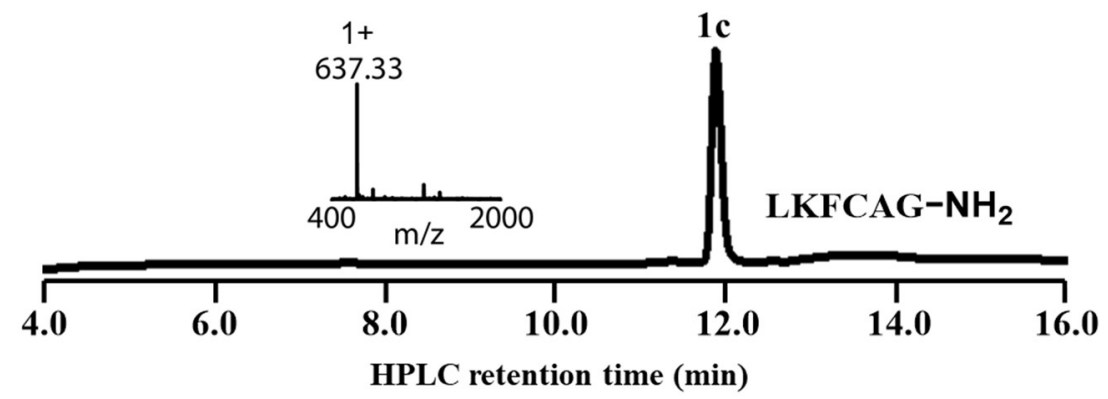

Figure S47. Analytical HPLC (using XSelect C18 column $(3.5 \mu \mathrm{m}, 130 \AA, 4.6 \times 150 \mathrm{~mm}$ ) at 220 $\mathrm{nm})$ and ESI-MS of 1c $\left([\mathrm{M}+\mathrm{H}]^{+}\right.$obs. 637.33, calc. 637.35). 


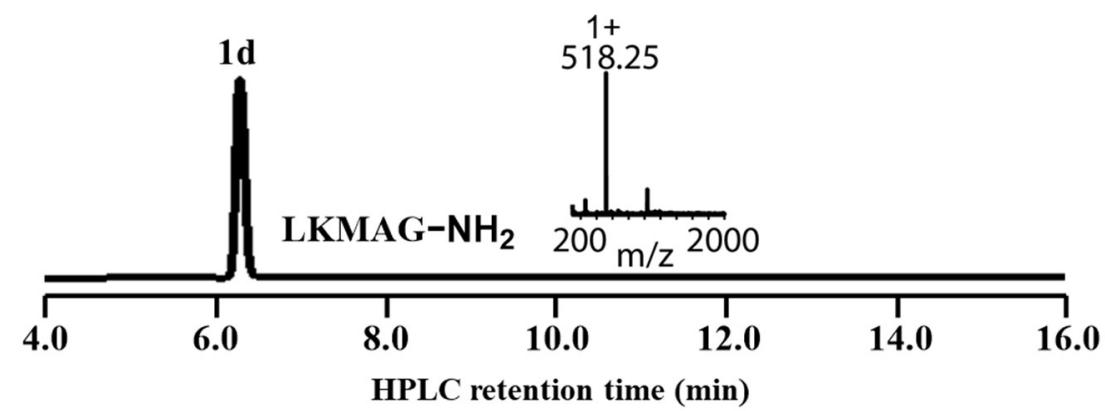

Figure S48. Analytical HPLC (using XSelect C18 column $(3.5 \mu \mathrm{m}, 130 \AA, 4.6 \times 150 \mathrm{~mm})$ at 220 $\mathrm{nm})$ and ESI-MS of $\mathbf{1 d}\left([\mathrm{M}+\mathrm{H}]^{+}\right.$obs. 518.25, calc. 518.31).

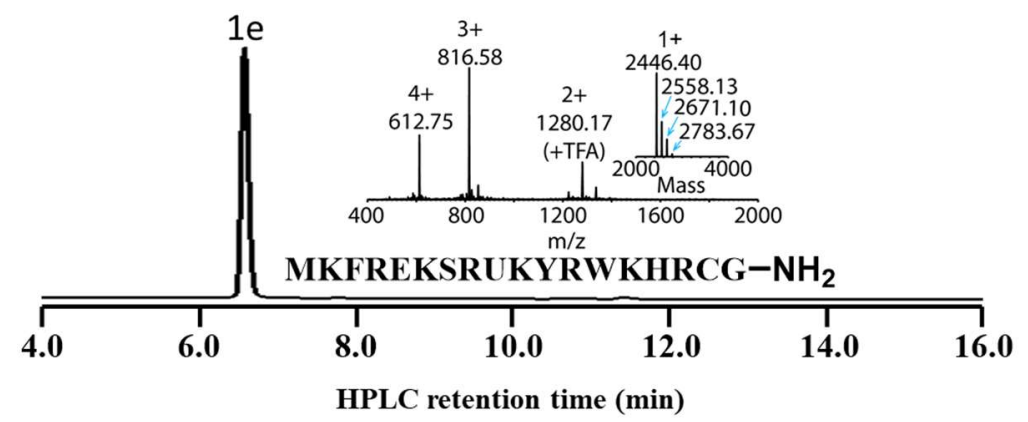

Figure S49. Analytical HPLC (using XSelect C18 column $(3.5 \mu \mathrm{m}, 130 \AA, 4.6 \times 150 \mathrm{~mm})$ at 220 $\mathrm{nm}$ ) and ESI-MS of reduced $1 \mathrm{e}$ (with TCEP/sodium ascorbate, $[\mathrm{M}+\mathrm{H}]^{+}$obs. 2446.40, calc. 2446.19; 2558.13, 2671.10 and 2783.67 are [M+TFA], [M+2TFA] and [M+3TFA], respectively).

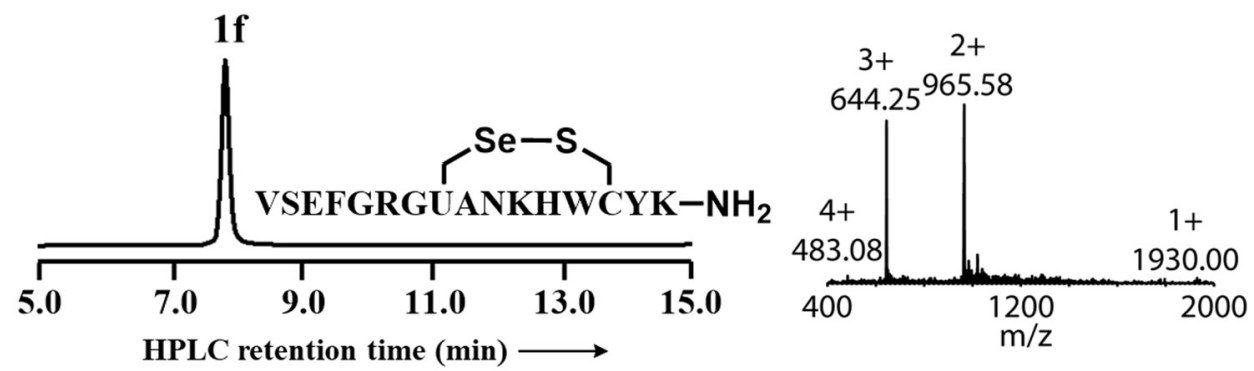

Figure S50. Analytical HPLC (using XSelect C18 column $(3.5 \mu \mathrm{m}, 130 \AA, 4.6 \times 150 \mathrm{~mm})$ at 220 $\mathrm{nm})$ and ESI-MS of $\mathbf{1 f}\left([\mathrm{M}+\mathrm{H}]^{+}\right.$obs. 1930.00, calc. 1929.81).

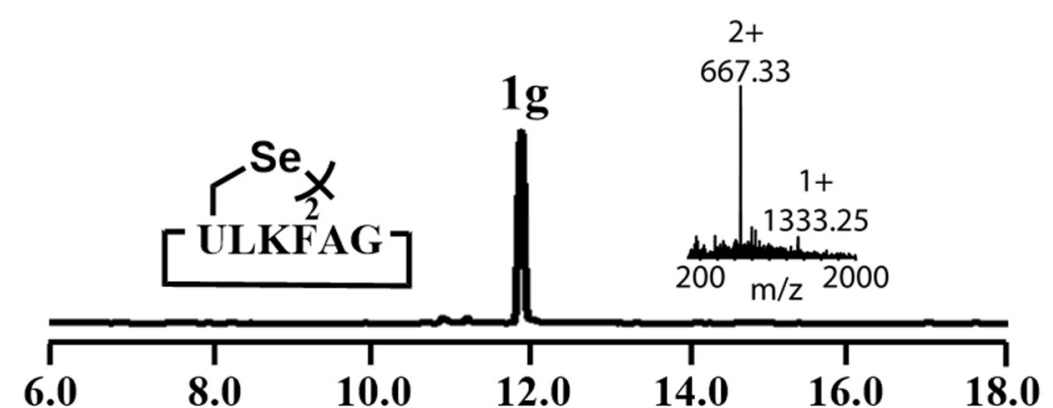

Figure S51. Analytical HPLC (using XSelect C18 column $(3.5 \mu \mathrm{m}, 130 \AA, 4.6 \times 150 \mathrm{~mm})$ at 220 


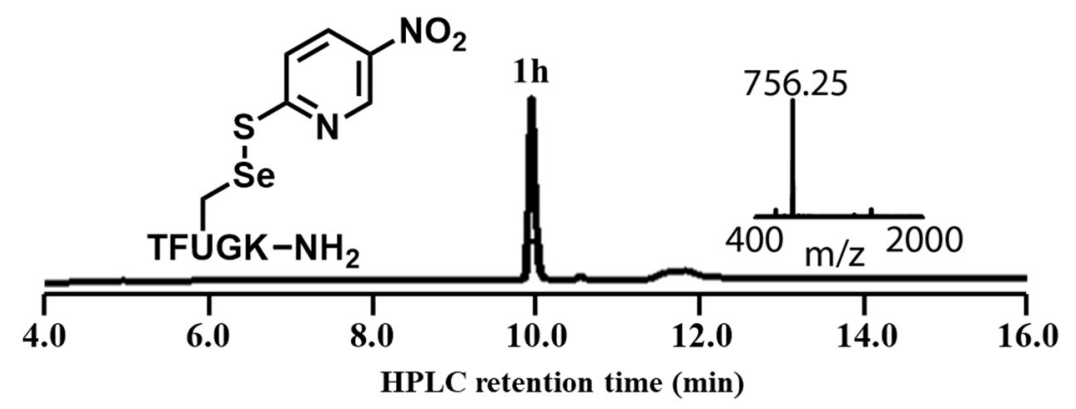

Figure S52. Analytical HPLC (using XSelect C18 column $(3.5 \mu \mathrm{m}, 130 \AA, 4.6 \times 150 \mathrm{~mm})$ at 220 $\mathrm{nm})$ and ESI-MS of $\mathbf{1 h}\left([\mathrm{M}+\mathrm{H}]^{+}\right.$obs. 756.25 , calc. 756.20).

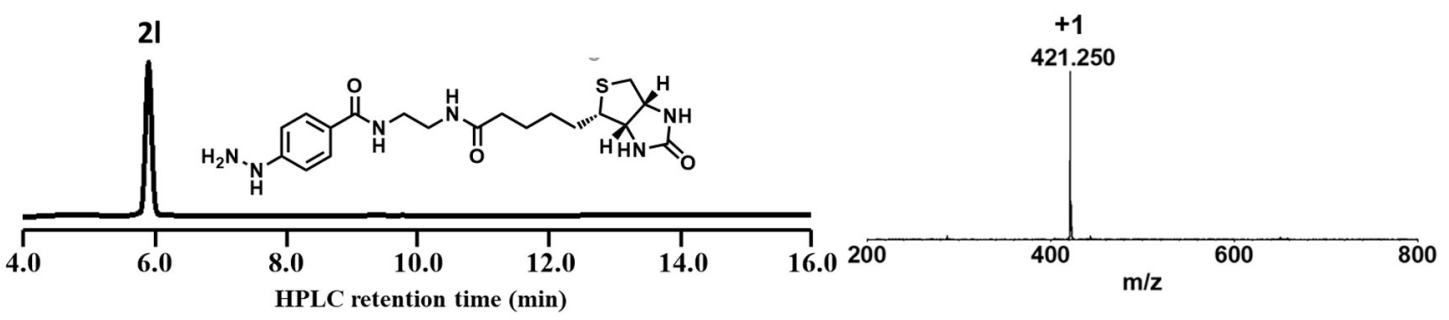

Figure S53. Analytical HPLC (using XSelect C18 column $(3.5 \mu \mathrm{m}, 130 \AA, 4.6 \times 150 \mathrm{~mm})$ at 220 $\mathrm{nm})$ and ESI-MS of $\mathbf{2 l}\left([\mathrm{M}+\mathrm{H}]^{+}\right.$obs. 421.250, calc. 421.201).

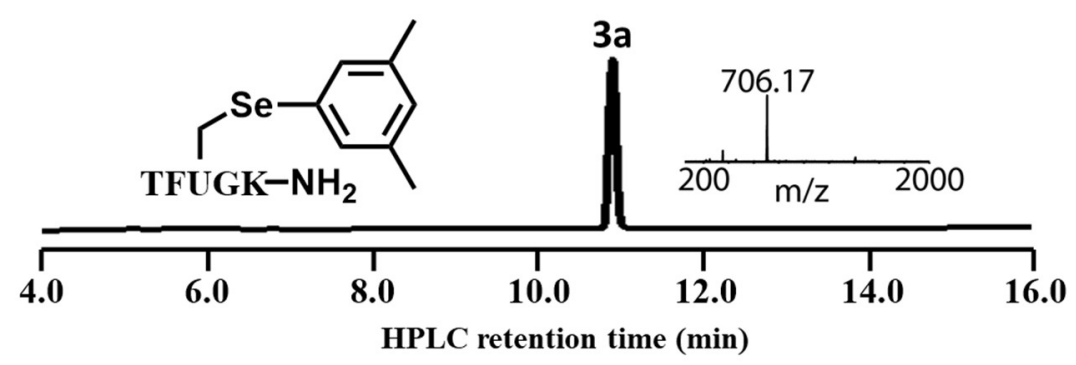

Figure S54. Analytical HPLC (using XSelect C18 column $(3.5 \mu \mathrm{m}, 130 \AA, 4.6 \times 150 \mathrm{~mm})$ at 220 $\mathrm{nm})$ and ESI-MS of 3a $\left([\mathrm{M}+\mathrm{H}]^{+}\right.$obs. 706.17, calc. 706.28).

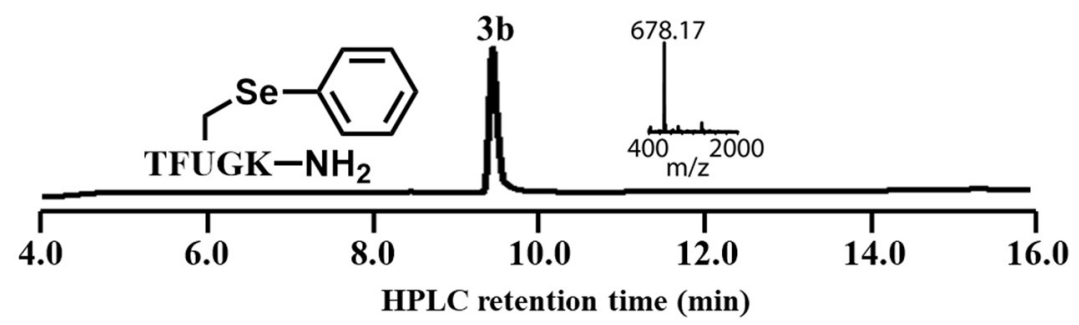

Figure S55. Analytical HPLC (using XSelect C18 column $(3.5 \mu \mathrm{m}, 130 \AA, 4.6 \times 150 \mathrm{~mm})$ at 220 $\mathrm{nm})$ and ESI-MS of $\mathbf{3 b}\left([\mathrm{M}+\mathrm{H}]^{+}\right.$obs. 678.17, calc. 678.25). 


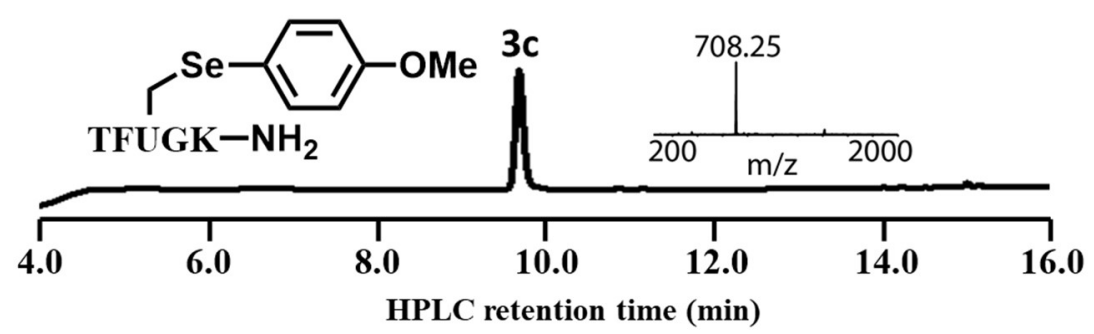

Figure S56. Analytical HPLC (using XSelect C18 column $(3.5 \mu \mathrm{m}, 130 \AA, 4.6 \times 150 \mathrm{~mm})$ at 220 $\mathrm{nm})$ and ESI-MS of $\mathbf{3 c}\left([\mathrm{M}+\mathrm{H}]^{+}\right.$obs. 708.25, calc. 708.26).

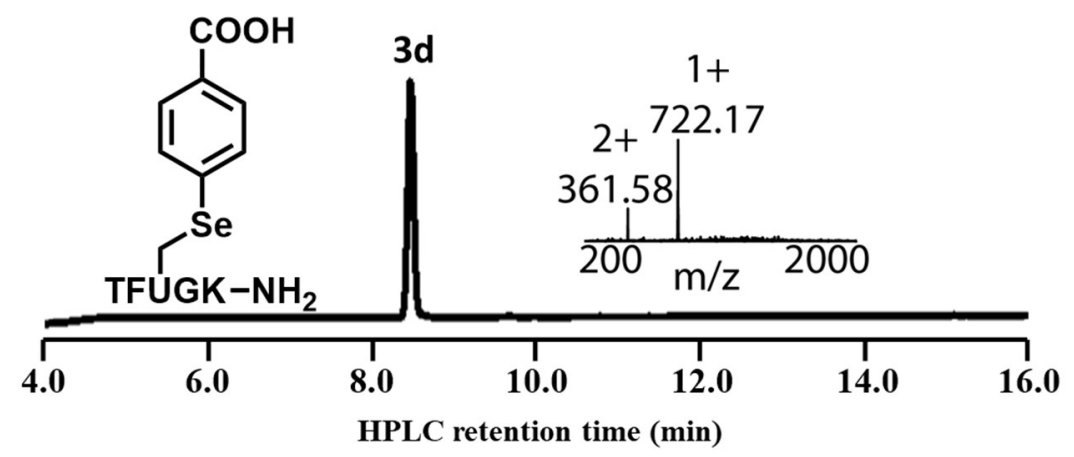

Figure S57. Analytical HPLC (using XSelect C18 column $(3.5 \mu \mathrm{m}, 130 \AA, 4.6 \times 150 \mathrm{~mm}$ ) at 220 $\mathrm{nm})$ and ESI-MS of $\mathbf{3 d}\left([\mathrm{M}+\mathrm{H}]^{+}\right.$obs. 722.17, calc. 722.24).

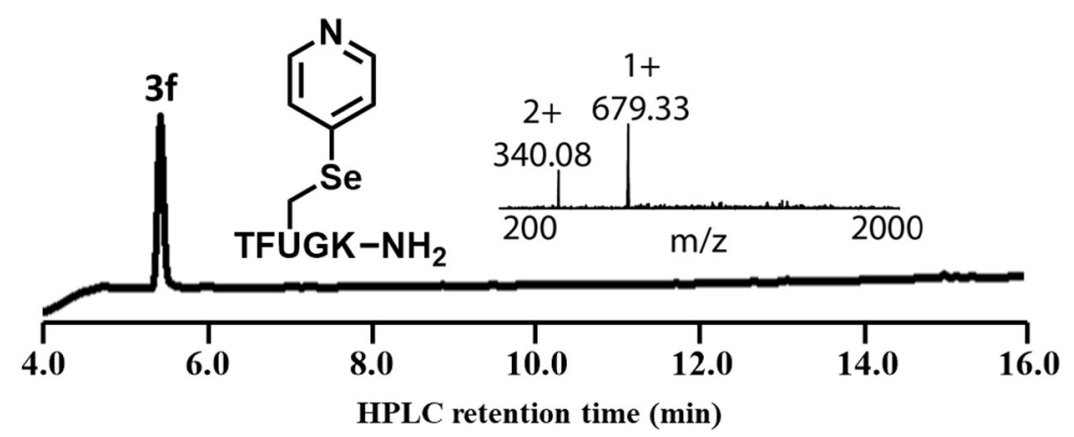

Figure S58. Analytical HPLC (using XSelect C18 column $(3.5 \mu \mathrm{m}, 130 \AA, 4.6 \times 150 \mathrm{~mm}$ ) at 220 $\mathrm{nm})$ and ESI-MS of $\mathbf{3 f}\left([\mathrm{M}+\mathrm{H}]^{+}\right.$obs. 679.33, calc. 679.25).

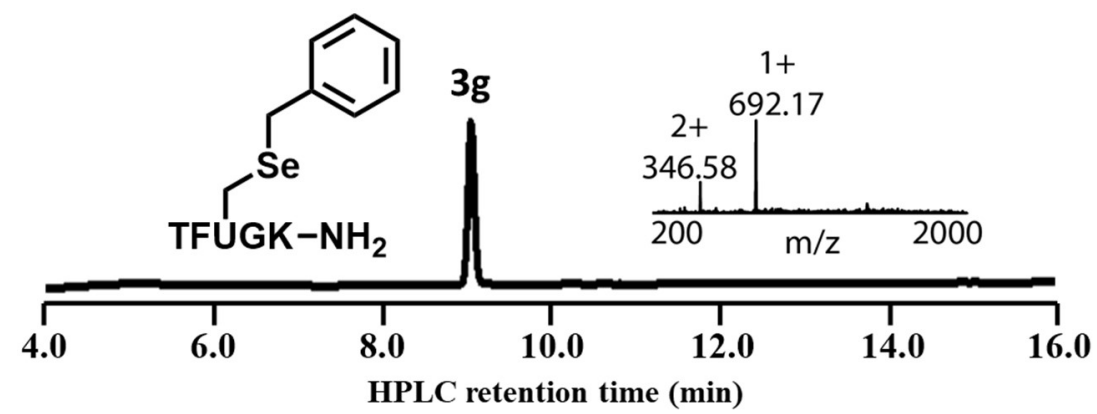

Figure S59. Analytical HPLC (using XSelect C18 column $(3.5 \mu \mathrm{m}, 130 \AA, 4.6 \times 150 \mathrm{~mm})$ at 220 $\mathrm{nm})$ and ESI-MS of $\mathbf{3 g}\left([\mathrm{M}+\mathrm{H}]^{+}\right.$obs. 692.17 , calc. 692.27). 


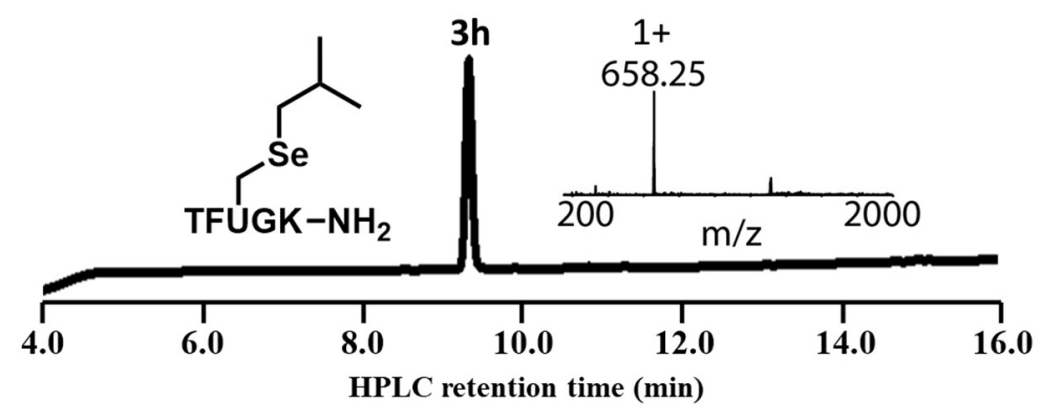

Figure S60. Analytical HPLC (using XSelect C18 column $(3.5 \mu \mathrm{m}, 130 \AA, 4.6 \times 150 \mathrm{~mm})$ at 220 $\mathrm{nm}$ ) and ESI-MS of $\mathbf{3 h}$ (obs. 658.25, calc. for $\left.[\mathrm{M}+\mathrm{H}]^{+} 658.28\right)$.

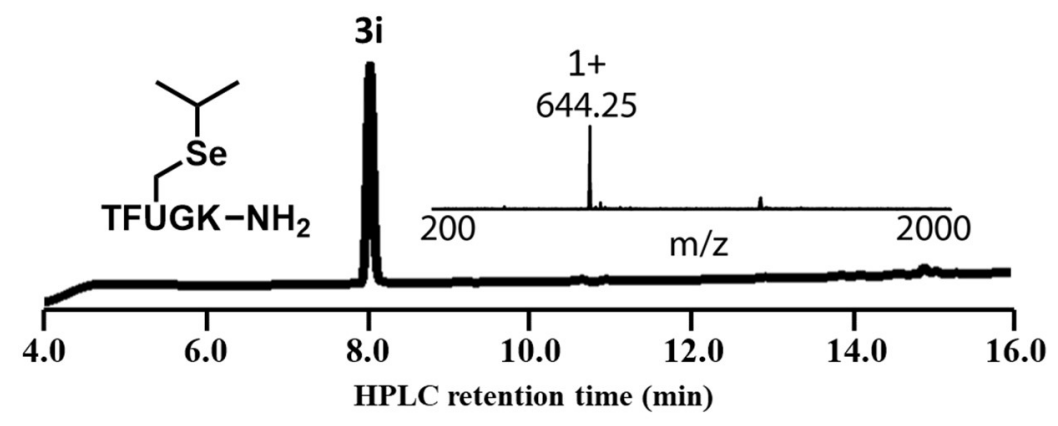

Figure S61. Analytical HPLC (using XSelect C18 column $(3.5 \mu \mathrm{m}, 130 \AA, 4.6 \times 150 \mathrm{~mm})$ at 220 $\mathrm{nm})$ and ESI-MS of 3i $\left([\mathrm{M}+\mathrm{H}]^{+}\right.$obs. 644.25, calc. 644.27).

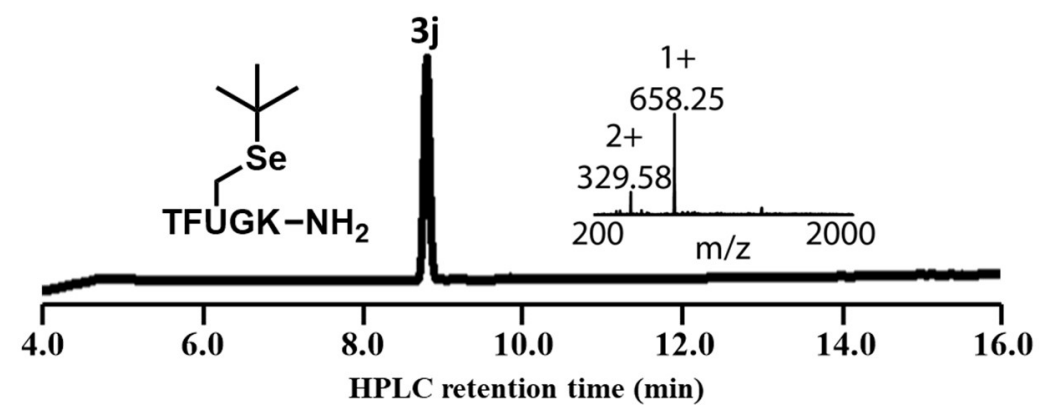

Figure S62. Analytical HPLC (using XSelect C18 column $(3.5 \mu \mathrm{m}, 130 \AA, 4.6 \times 150 \mathrm{~mm})$ at 220 $\mathrm{nm})$ and ESI-MS of $\mathbf{3 j}\left([\mathrm{M}+\mathrm{H}]^{+}\right.$obs. 658.25 , calc. 658.28$)$.

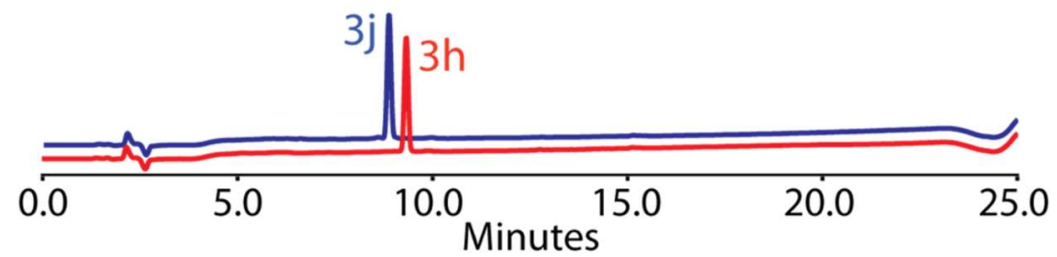

Figure S63. Analytical HPLC (using XSelect C18 column $(3.5 \mu \mathrm{m}, 130 \AA, 4.6 \times 150 \mathrm{~mm})$ at 220 $\mathrm{nm})$ and ESI-MS of $\mathbf{3 h}$ and $\mathbf{3} \mathbf{j}$. 


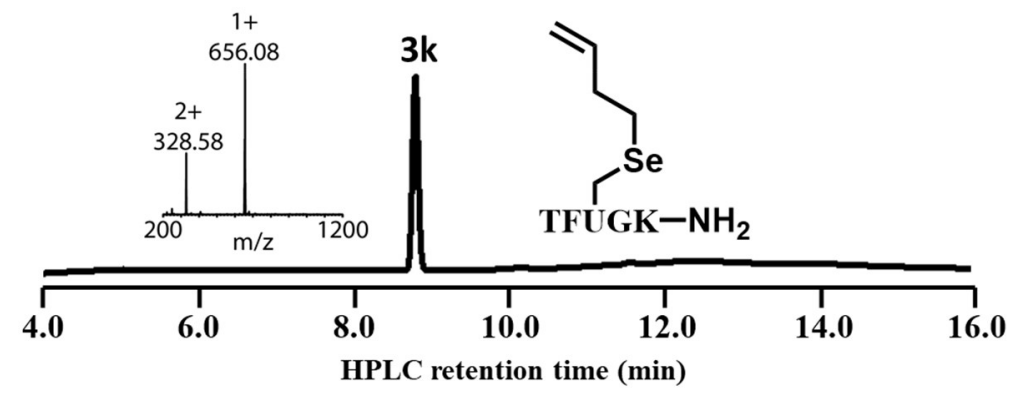

Figure S64. Analytical HPLC (using XSelect C18 column $(3.5 \mu \mathrm{m}, 130 \AA, 4.6 \times 150 \mathrm{~mm})$ at 220 $\mathrm{nm})$ and ESI-MS of 3k ([M+H] $]^{+}$obs. 656.08, calc. 656.27).

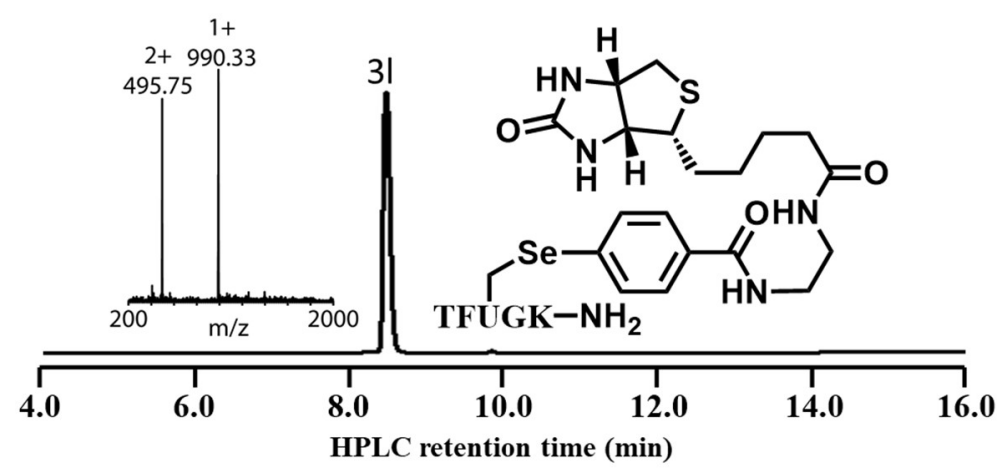

Figure S65. Analytical HPLC (using XSelect C18 column $(3.5 \mu \mathrm{m}, 130 \AA, 4.6 \times 150 \mathrm{~mm})$ at 220 $\mathrm{nm})$ and ESI-MS of $\mathbf{3 1}\left([\mathrm{M}+\mathrm{H}]^{+}\right.$obs. 990.33, calc. 990.38).
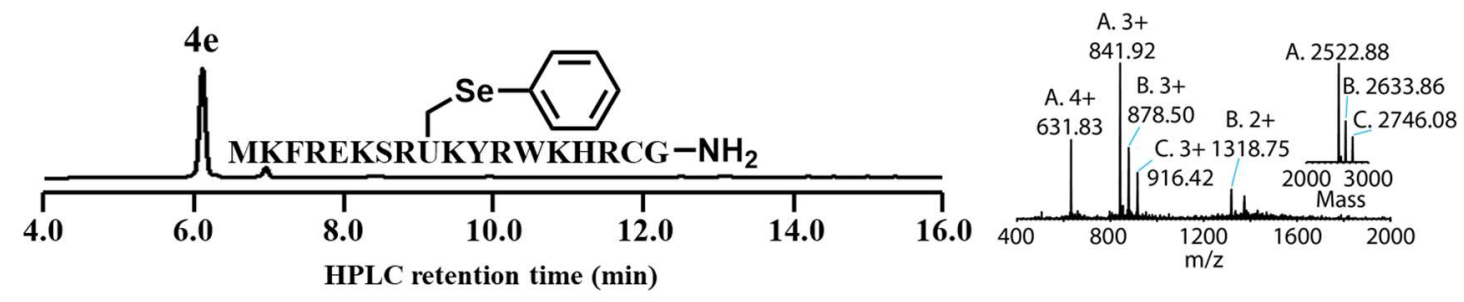

Figure S66. Analytical HPLC (using XSelect C18 column $(3.5 \mu \mathrm{m}, 130 \AA, 4.6 \times 150 \mathrm{~mm})$ at 220 $\mathrm{nm}$ ) and ESI-MS of $4 \mathbf{e}$ (mass obs. 2522.88 Da, calc. $2522.19 \mathrm{Da}$; B and C are [M+TFA] and [M+2TFA] adduct, respectively.).

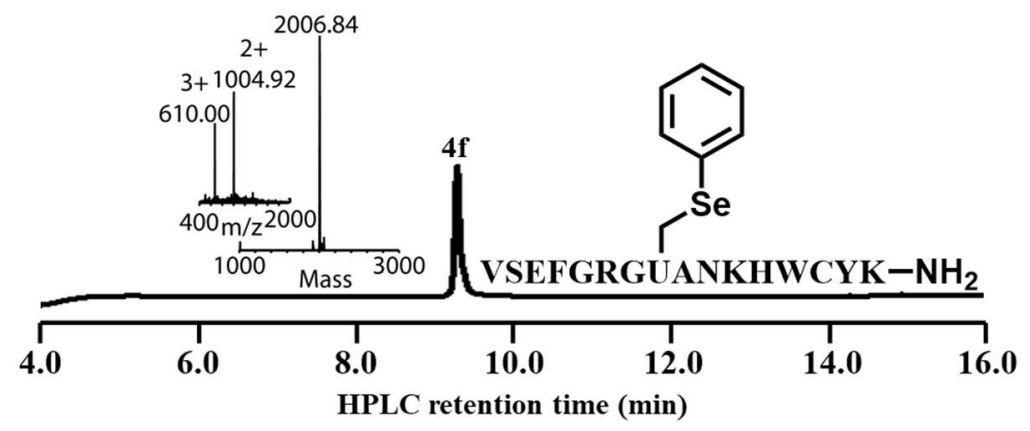

Figure S67. Analytical HPLC (using XSelect C18 column $(3.5 \mu \mathrm{m}, 130 \AA, 4.6 \times 150 \mathrm{~mm})$ at 220 $\mathrm{nm}$ ) and ESI-MS of $\mathbf{4 f}$ (mass obs. 2006.84 Da, calc. 2006.85 Da). 


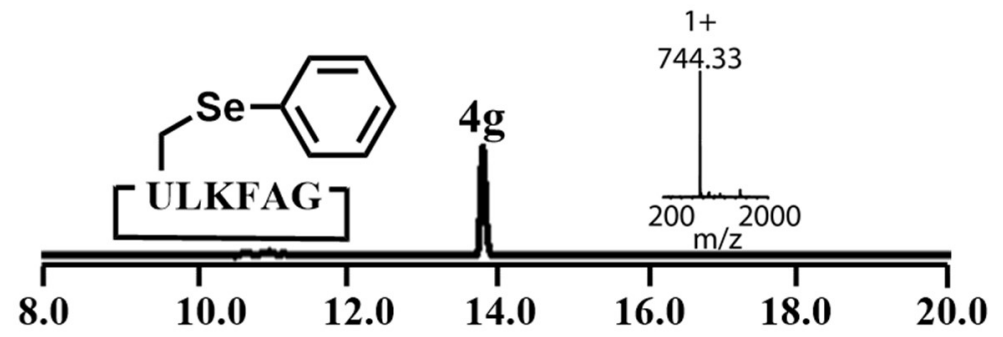

Figure S68. Analytical HPLC (using XSelect C18 column $(3.5 \mu \mathrm{m}, 130 \AA, 4.6 \times 150 \mathrm{~mm})$ at 220 $\mathrm{nm})$ and ESI-MS of $\mathbf{4 g}\left([\mathrm{M}+\mathrm{H}]^{+}\right.$obs. 744.33 , calc. 744.30$)$.

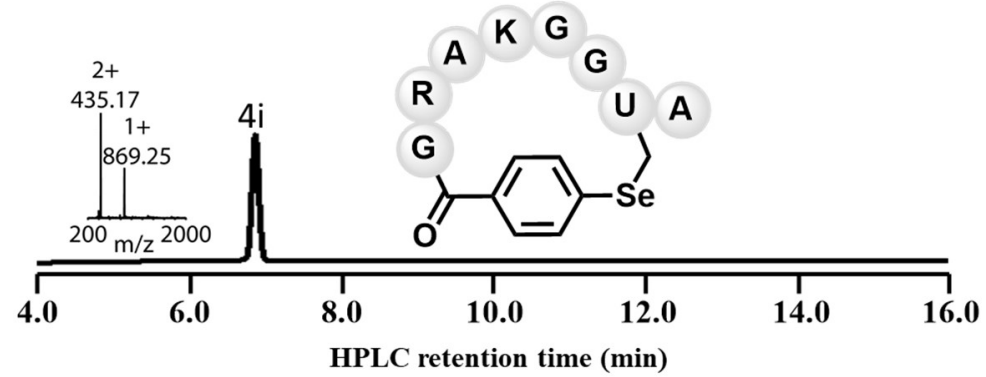

Figure S69. Analytical HPLC (using XSelect C18 column $(3.5 \mu \mathrm{m}, 130 \AA, 4.6 \times 150 \mathrm{~mm})$ at 220 $\mathrm{nm})$ and ESI-MS of $\mathbf{4 i}\left([\mathrm{M}+\mathrm{H}]^{+}\right.$obs. 869.25, calc. 869.32).

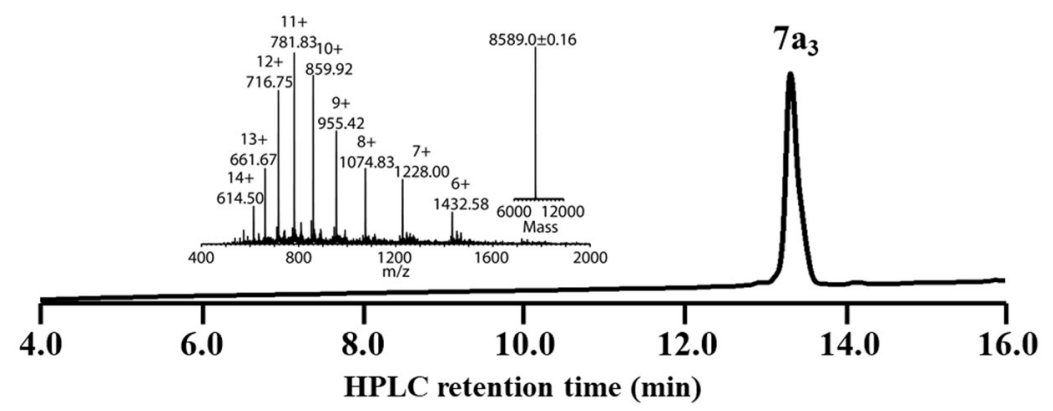

Figure S70. Analytical HPLC (using XSelect C4 column ( $3.5 \mu \mathrm{m}, 130 \AA, 4.6 \times 150 \mathrm{~mm}$ ) at $220 \mathrm{~nm}$ ) and ESI-MS of $7 \mathbf{a}_{3}$ (with TCEP/sodium ascorbate, mass obs. 8589.00 Da, calc. average 8589.16 $\mathrm{Da})$.

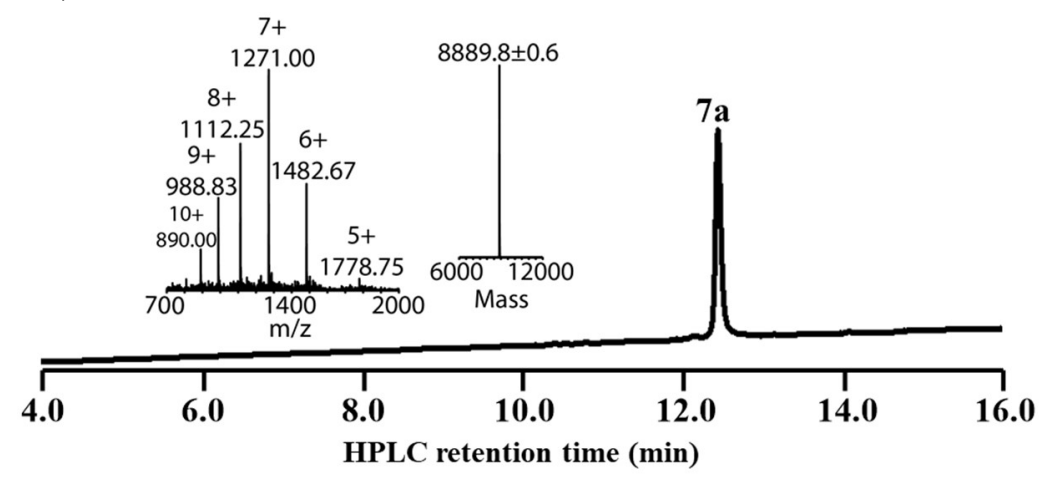

Figure S71. Analytical HPLC (using XSelect C4 column ( $3.5 \mu \mathrm{m}, 130 \AA, 4.6 \times 150 \mathrm{~mm}$ ) at $220 \mathrm{~nm}$ ) and ESI-MS of 7a (mass obs. $8889.8 \mathrm{Da}$, calc. average 8890.4 Da). 


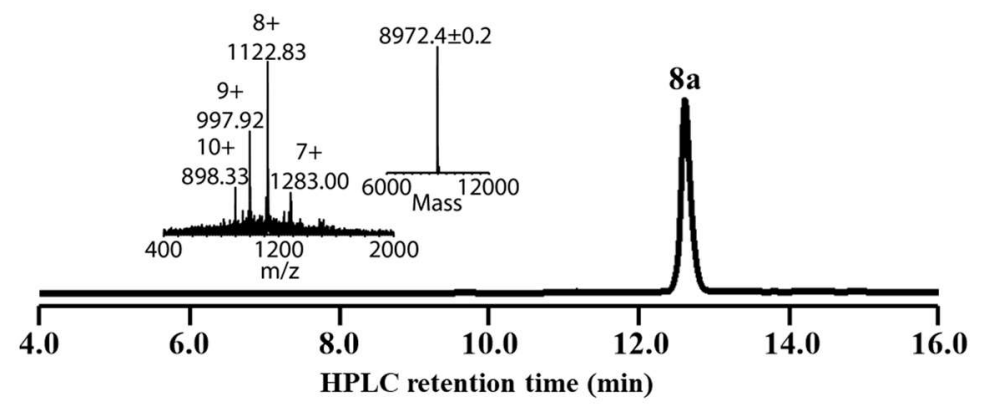

Figure S72. Analytical HPLC (using XSelect C4 column $(3.5 \mu \mathrm{m}, 130 \AA, 4.6 \times 150 \mathrm{~mm}$ ) at $220 \mathrm{~nm}$ ) and ESI-MS of 8a (mass obs. 8972.4 Da, calc. isotopic average 8972.6 Da).

a.

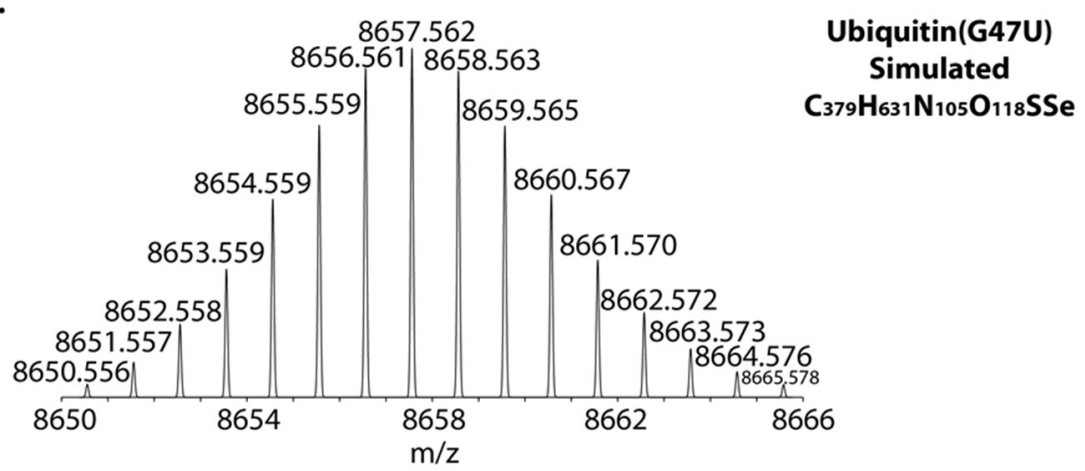

b.

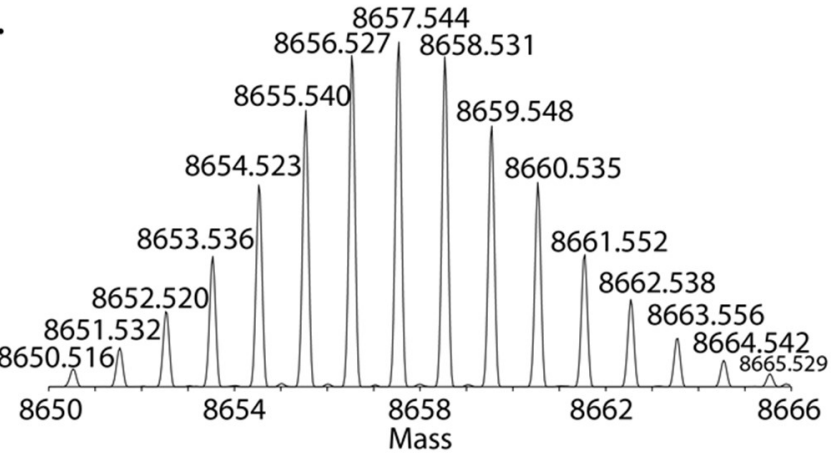

deconvoluted

Figure S73. HR-MS analysis of ubiquitin(G47U), 5a. a. The simulated HR-MS of reduced form of ubiquitin (G47U), 5a, with chemical formula $\mathrm{C}_{379} \mathrm{H}_{631} \mathrm{~N}_{105} \mathrm{O}_{118} \mathrm{SSe}$ is shown; $\mathbf{b}$. The deconvoluted HR-MS of 5a. 
a.

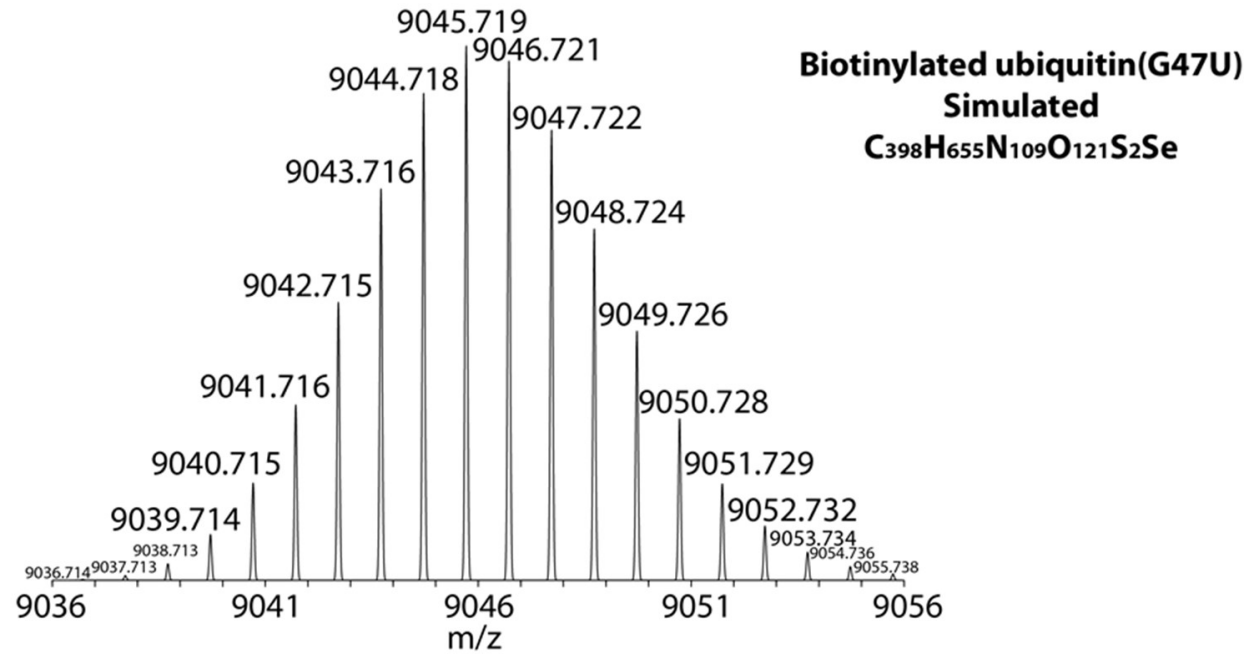

b.

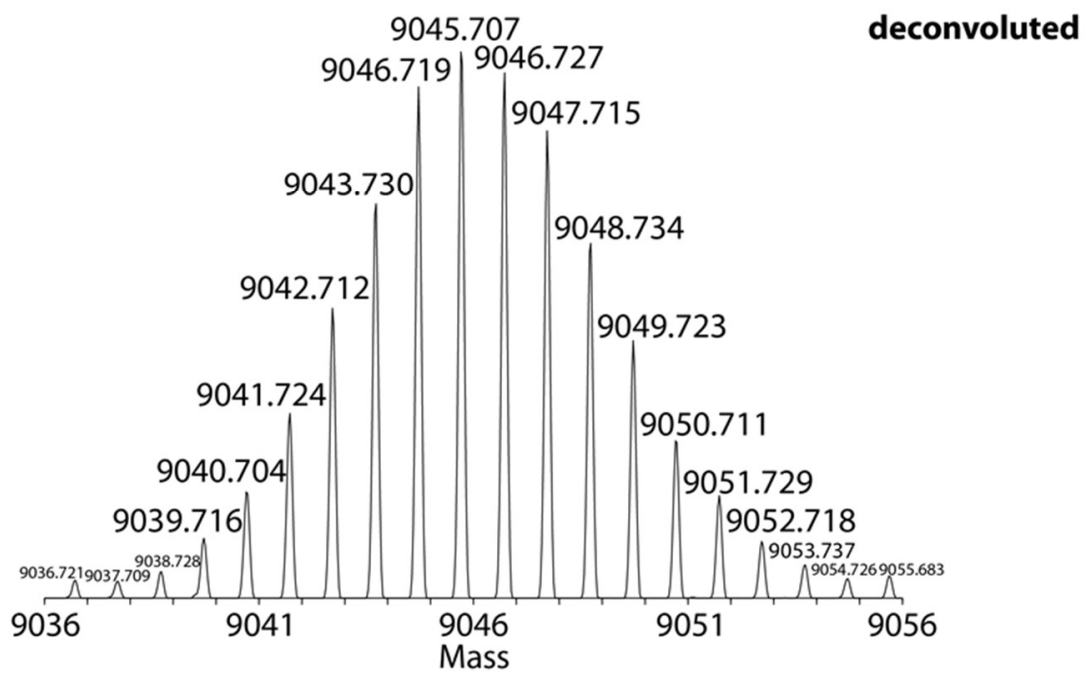

Figure S74. HR-MS analysis of biotinylated-biquitin(G47U), 6a. a. The simulated HR-MS of reduced form of biotinylated-modified ubiquitin(G47U) 6a with chemical formula $\mathrm{C}_{398} \mathrm{H}_{655} \mathrm{~N}_{109} \mathrm{O}_{121} \mathrm{~S}_{2} \mathrm{Se}$ is shown; b. The deconvoluted HR-MS of $6 \mathbf{a}$. 

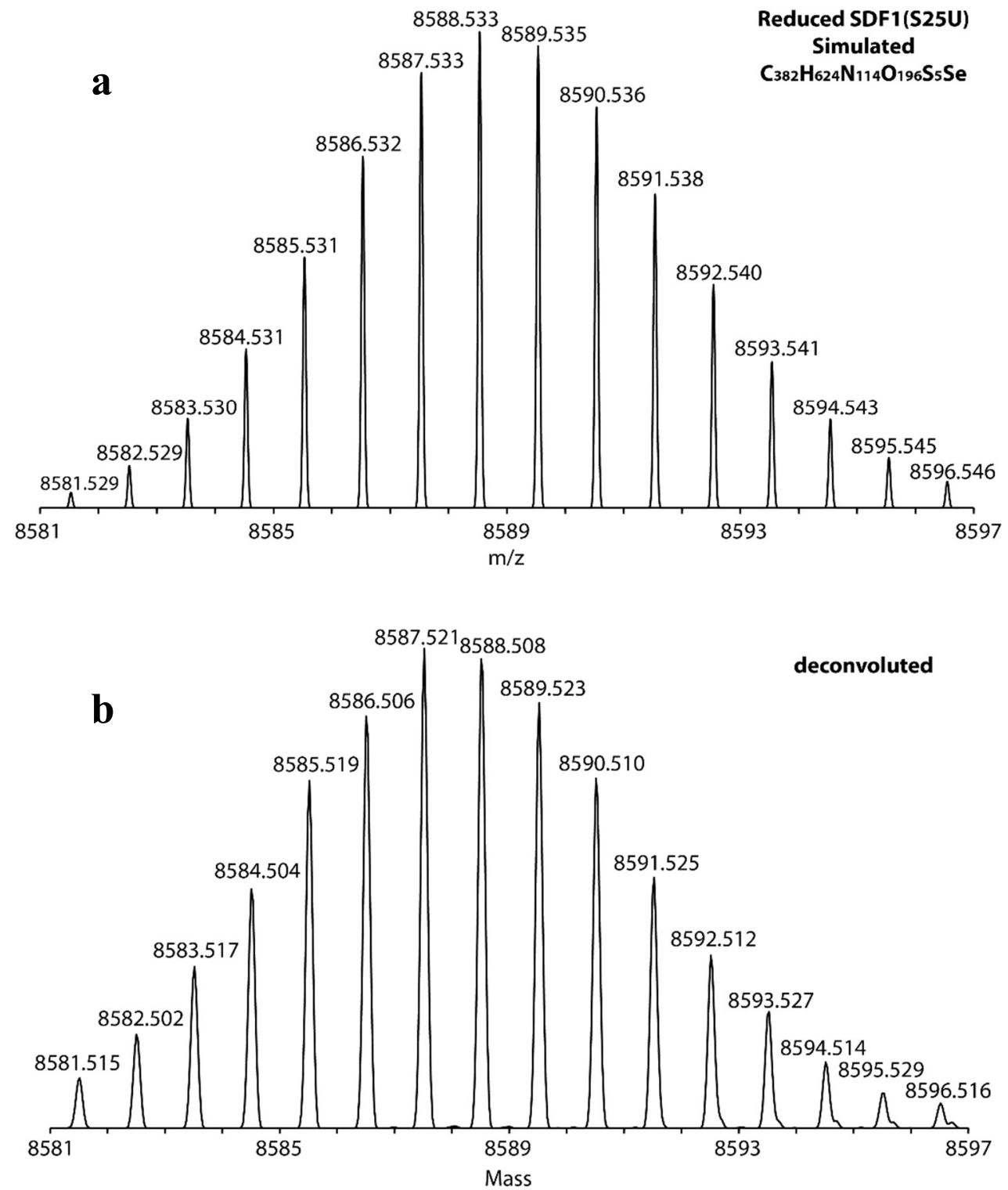

Figure S75. HR-MS analysis of reduced SDF1(S25U), 7a $\mathbf{a}_{3}$ a. The simulated HR-MS of reduced $\mathrm{SDF} 1(\mathrm{~S} 25 \mathrm{U}), \mathbf{7 a}_{3}$ with chemical formula $\mathrm{C}_{382} \mathrm{H}_{624} \mathrm{~N}_{114} \mathrm{O}_{96} \mathrm{~S}_{5} \mathrm{Se}$ is shown; $\mathbf{b}$. The deconvoluted HRMS of $7 \mathbf{a}_{3}$. 

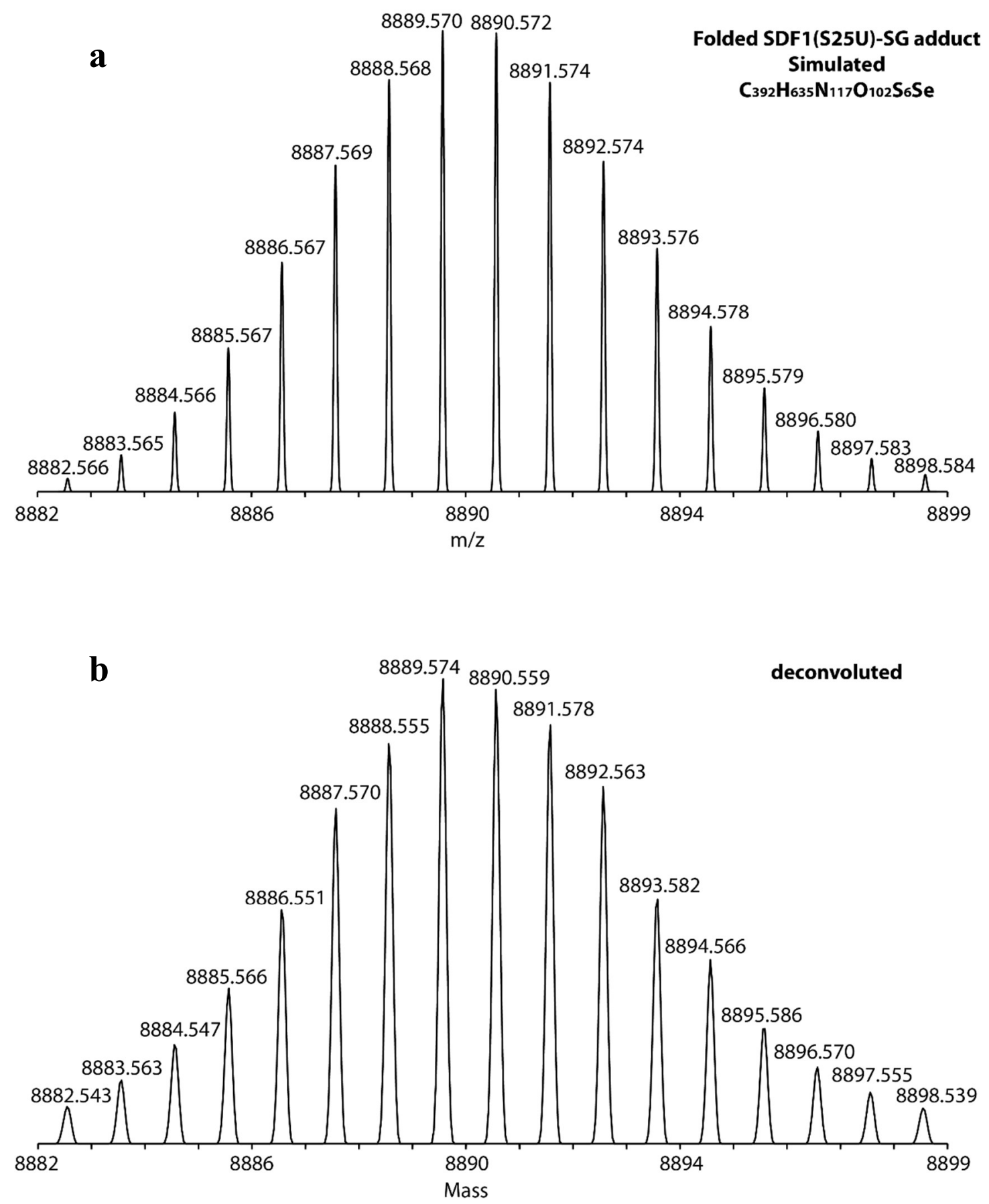

Figure S76. HR-MS analysis of folded SDF1(S25U)-SG adduct, 7a. a. The simulated HR-MS of folded SDF1(S25U) GSH adduct, 7a with chemical formula $\mathrm{C}_{392} \mathrm{H}_{635} \mathrm{~N}_{117} \mathrm{O}_{102} \mathrm{~S}_{6} \mathrm{Se}$ is shown; $\mathbf{b}$. The deconvoluted HR-MS of $7 \mathbf{a}$. 

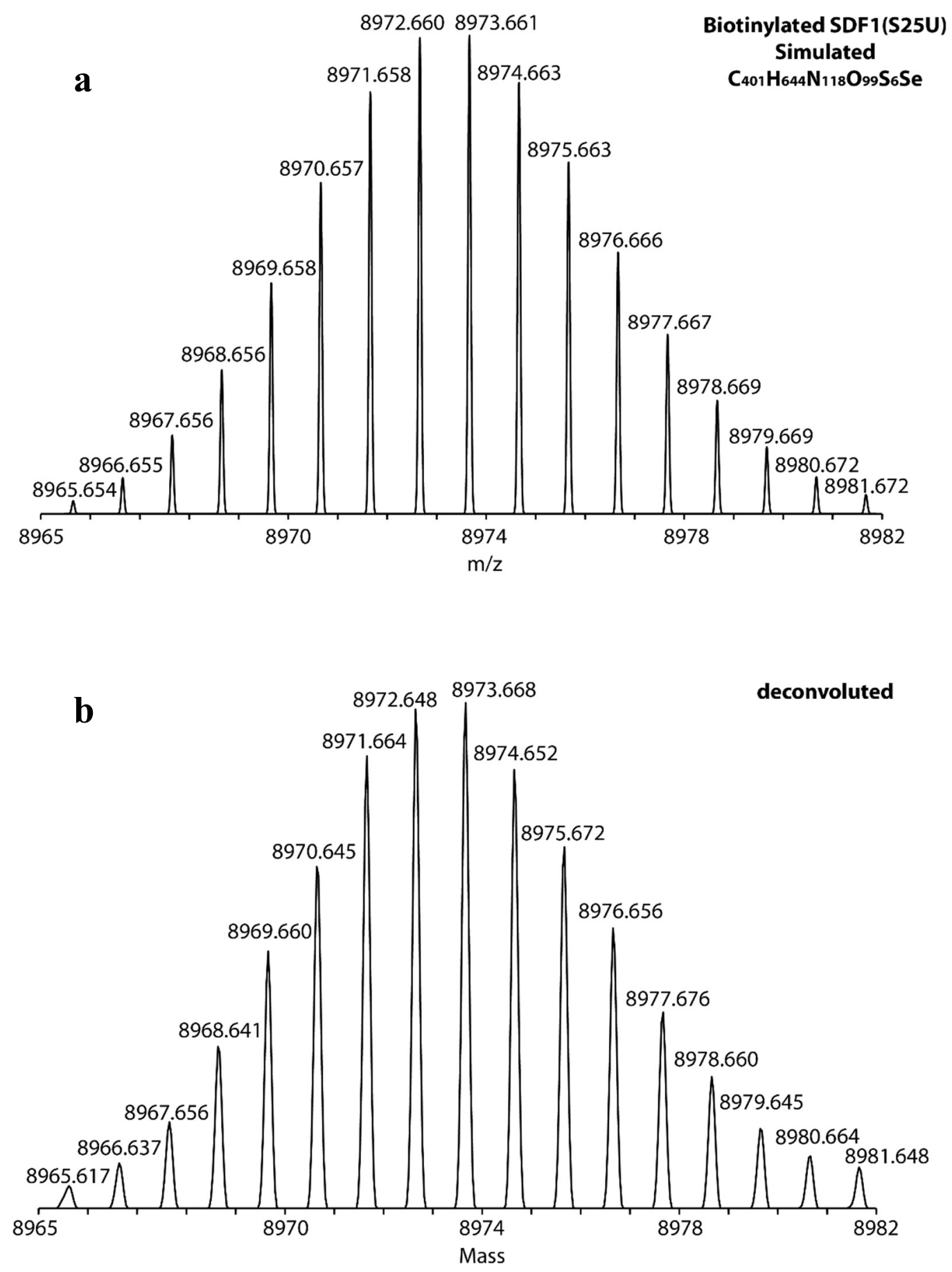

Figure S77. HR-MS analysis of biotinylated SDF1(S25U), 8a. a. The simulated HR-MS of biotinylated SDF1(S25U), 8a with chemical formula $\mathrm{C}_{401} \mathrm{H}_{644} \mathrm{~N}_{118} \mathrm{O}_{99} \mathrm{~S}_{6} \mathrm{Se}$ is shown; $\mathbf{b}$. The deconvoluted HR-MS of $\mathbf{8 a}$. 

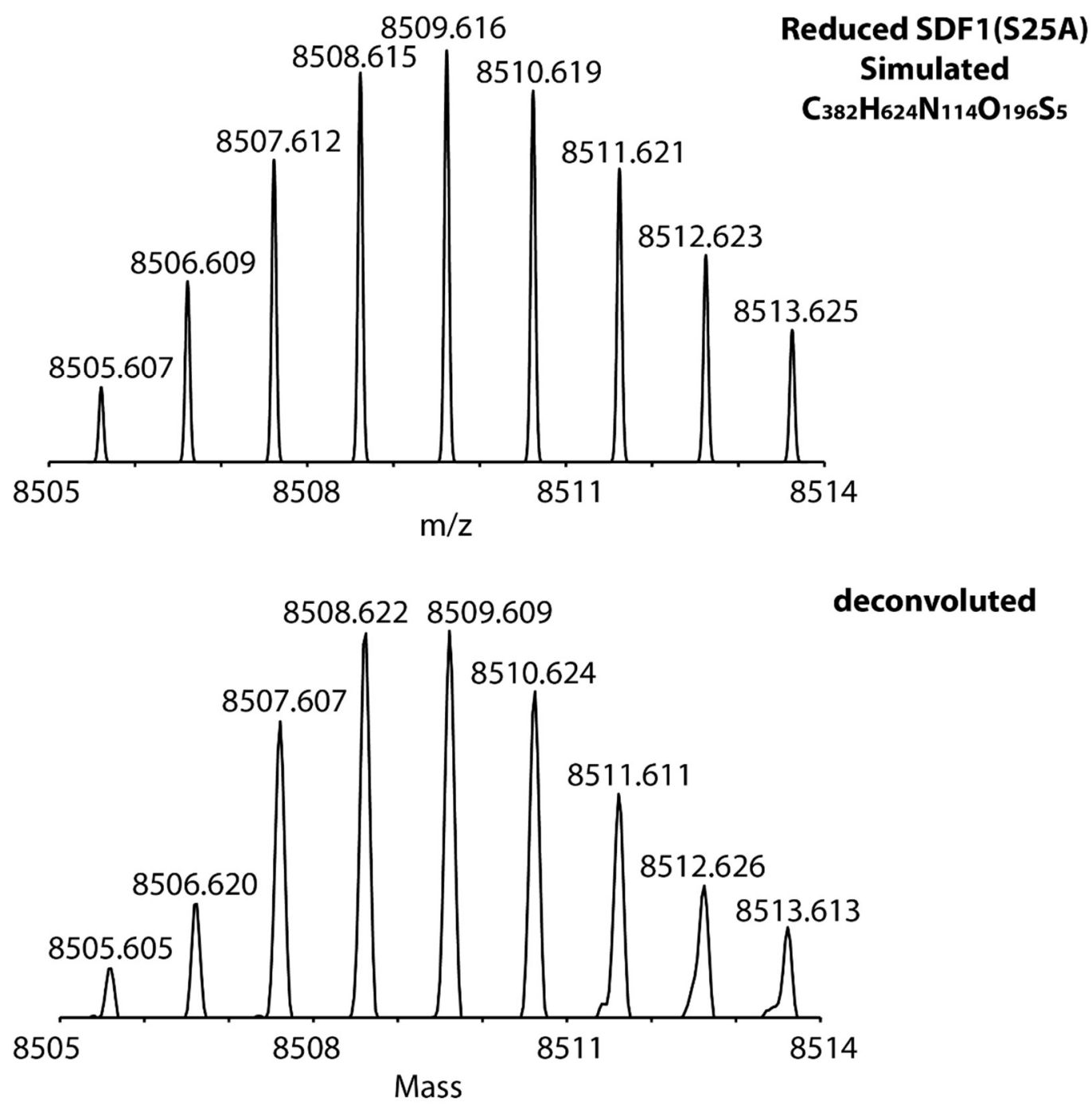

Figure S78. HR-MS analysis of SDF1(S25A), 9a. a. The simulated HR-MS of SDF1(S25A), 9a with chemical formula $\mathrm{C}_{382} \mathrm{H}_{624} \mathrm{~N}_{114} \mathrm{O}_{196} \mathrm{~S}_{5}$ is shown; $\mathbf{b}$. The deconvoluted HR-MS of 9a. 


\section{References}

1. Gieselman, M. D.; Xie, L.; van der Donk, W. A., Synthesis of a Selenocysteine-Containing Peptide by Native Chemical Ligation. Org. Lett. 2001, 3, 1331-1334.

2. Harris, K. M.; Flemer, S.; Hondal, R. J., Studies on deprotection of cysteine and selenocysteine side-chain protecting groups. J. Pept. Sci. 2007, 13, 81-93.

3. Stoll, S.; Schweiger, A., EasySpin, a comprehensive software package for spectral simulation and analysis in EPR. J. Magn. Reson. 2006, 178 (1), 42-55.

4. Yoshioka, H.; Senba, Y.; Saito, K.; Kimura, T.; Hayakawa, F., Spin-Trapping Study on the Hydroxyl Radical Formed from a Tea Catechin-Cu(II) System. Biosci. Biotechnol. Biochem. 2001, 65 (8), 1697-1706.

5. Zhao, Z.; Metanis, N., Utilizing Copper-Mediated Deprotection of Selenazolidine for Cyclic Peptide Synthesis. J. Org. Chem. 2020, 85, 1731-1739.

6. Zheng, J.-S.; Tang, S.; Qi, Y.-K.; Wang, Z.-P.; Liu, L., Chemical synthesis of proteins using peptide hydrazides as thioester surrogates. Nat. Protoc. 2013, 8, 2483-2495.

7. Flood, D. T.; Hintzen, J. C. J.; Bird, M. J.; Cistrone, P. A.; Chen, J. S.; Dawson, P. E., Leveraging the Knorr Pyrazole Synthesis for the Facile Generation of Thioester Surrogates for use in Native Chemical Ligation. Angew. Chem. Int. Ed. 2018, 57, 11634-11639.

8. Murphy, J. W.; Cho, Y.; Sachpatzidis, A.; Fan, C.; Hodsdon, M. E.; Lolis, E., Structural and Functional Basis of CXCL12 (Stromal Cell-derived Factor-1 $\alpha$ ) Binding to Heparin*. J. Biol. Chem. 2007, 282 (13), 10018-10027. 